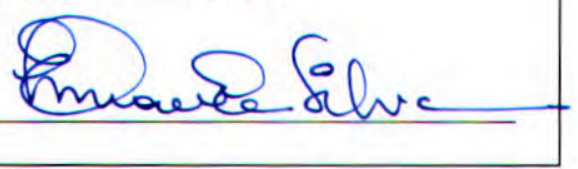

\title{
Um Método para Avaliação de Qualidade de Pacotes de Software na Área de Sistemas de Informação
}

\section{Cristiane Sônia Arroyo}

Orientador: Prof. Dr. José Carlos Maldonado

Dissertação apresentada ao Instituto de Ciências Matemáticas e de Computação - ICMC/USP, como parte dos requisitos para obtenção do título de Mestre em Ciências - Área de Ciências de Computação e Matemática Computacional. 


\section{Agradecimentos}

Ao meu orientador, Prof. Dr. José Carlos Maldonado, pela dedicação e orientação deste trabalho.

À Prof. Dra. Rosely Sanches, pelo incentivo e colaboração para a realização deste trabalho.

Aos meus pais, Zuleika e Pedro, pela minha formação e apoio durante ao longo de minha vida.

À minha irmã, Paula, pela amizade e ajuda nas horas mais dificeis.

À Ceterp - Centrais Telefônicas de Ribeirão Preto S/A que tornou possível a realização da pesquisa de campo.

Adriana Noronha, Guatabi B. da C. Bortolin, Luís Ricardo de Figueiredo e Marília Guimarães, Rosana C. de M. Grillo Gonçalves, obrigado pela contribuição e sugestões para este trabalho.

Aos colegas da informática da Ceterp S/A pelo apoio recebido, especialmente André, Aroldo, Jorge, Maurício, Rinaldo, Ruth e Wanderley.

A atenção dispensada pelos funcionários do ICMSC. 


\section{RESUMO}

A avaliação de pacotes de software em um ambiente empresarial pode ser realizada pelas pessoas que não são técnicas na área de informática utilizando as características de qualidade de produto de software da ISO/IEC 9126 e de outras encontradas na literatura, através da aplicação de um questionário. Um questionário é apresentado com sua elaboração baseada em estudos realizados conforme a norma ISO/IEC 9126 e o método Goal/Question/Metric (GQM). Um estudo de caso foi realizado usando seis pacotes de software de sistemas de informação em operação na CETERP S/A. O objetivo é proporcionar informação para o gerente no processo de análise e melhorar 0 apoio da tecnologia da informação disponível na empresa. 


\begin{abstract}
The evaluation of software packages in an industrial environment can be achieved by non-technical personnel in the software engineering area using the software product quality characteristics of ISO/IEC 9126 and of others standards found in the literature, using a questionnaire. A questionnaire is presented, elaborated based on previous studies, on ISO/IEC 9126 and on Goal/Question/Metric (GQM). A case study was conducted using six information system packages already in use at CETERP S/A. The aim is to provide information to the manager in the process of analysing and improving the information technology support available in the company.
\end{abstract}




\section{ÍNDICE}

Página

LISTA DE FIGURAS...................................................................... III

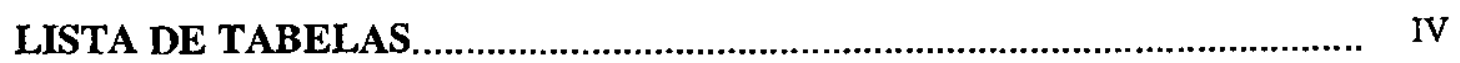

LISTA DE QUADROS........................................................................ VI

CAPÍTULO 1 - INTRODUÇÃo

1.1 Contexto e Motivação........................................................................ 1

1.2 Objetivos................................................................................ 4

1.3 Organização............................................................................. 5

\section{CAPÍTULO 2 - MODELOS DE QUALIDADE DE PRODUTO DE SOFTWARE}

2.1 Considerações Iniciais...................................................................... 6

2.1.1 A Qualidade de Produto de Software................................................................ 6

2.1.2 O Método GoaVQuestion/Metric................................................................... 12

2.2 Modelos de Qualidade de Produto de Software................................... 18

2.2.1 Modelo de Vidal............................................................................................... 18

2.2.2 Método do CTI........................................................................................ 24

2.2.3 Modelo de Belchior.................................................................................. 27

2.3 Considerações Finais................................................................. 32

\section{CAPÍtulo 3 - A PESQUiSA SOBRE A AVALIAÇÃo dA QUALIDAdE dE PACOTES DE SOFTWARE DA ÁREA DE SISTEMAS DE INFORMAÇÃO EM OPERAÇÃO}

3.1 Considerações Iniciais....................................................................... 34

3.2 Planejamento da Avaliação............................................................. 34

3.2.1 Passo 1: Objetivos da Pesquisa............................................................. 35

3.2.2 Passo 2: Lista de Questões de Interesse.......................................................... 35

3.2.3 Passo 3: Métricas...................................................................................... 46

3.2.4 Passo 4: Projeto e Teste do Questionário de Coleta de Dados............................. 50

3.2.5 Passo 5: Coleta e Validaçăo dos Dados e Passo 6: Análise dos Dados.............. 51

3.3 Considerações Finais......................................................................... 51 


\section{CAPÍTULO 4 - ESTUDO DE CASO}

4.1 Consideraçōes Iniciais................................................................... 52

4.2 Planejamento da Avaliação.......................................................... 52

4.2.1 Passo 1: Objetivos da Pesquisa.................................................................... 52

4.2.2 Passo 2: Lista de Questões de Interesse......................................................... 53

4.2.3 Passo 3: Méricas....................................................................................... 53

4.2.4 Passo 4: Projeto e Teste do Questionário de Coleta de Dados........................... 54

4.2.5 Passo 5: Coleta e Validação dos Dados.............................................................. 54

4.2.6 Passo 6: Análise dos Dados...................................................................... 54

4.3 Considerações Finais.................................................................... 104

\section{CAPÍTULO 5 - CONCLUSÃO}

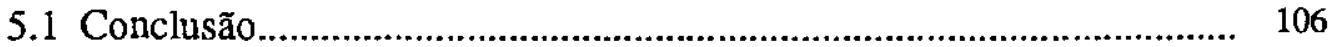

5.2 Trabalhos Futuros...................................................................... 107

REFERÊNCIAS BIBLIOGRÁFICAS............................................................. 108

ANEXO 1 - O Questionário de Avaliação da Qualidade de Pacotes de 113 Software na Área de Sistemas de Informação. 


\section{LISTA DE FIGURAS}

\section{Página}

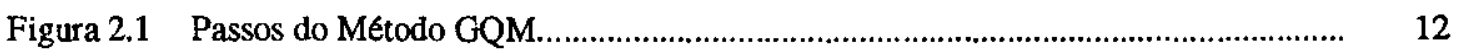

Figura 2.2 Estrutura Hierárquica do Método GQM................................................................... 13

Figura 2.3 Coordenadas da Meta do Método GQM................................................................. 14

Figura 3.1 Módulos de Avaliação da Qualidade de Pacotes de Software.................................... 37 


\section{LISTA DE TABELAS}

Página

Tabela 3.1 Tabela de Peso da Escala de Classificaçãa............................................................. 46

Tabela 4.1 Quantidade de Entrevistados por Pacotes de Softwares......................................... 55

Tabela 4.2 Quantidade de Entrevistados por Módulos de Avaliação.......................................... 55

Tabela 4.3 Módulo 1 Adequação - Pacote de Software: Folha de Pagamento e Administração de Recursos Humanos..................................................................... 56

Tabela 4.4 Módulo 2 Documentação - Pacote de Software: Folha de Pagamento e Administração de Recursos Humanos.

Tabela 4.5 Módulo 3 Serviços de Manutenção - Pacote de Software: Folha de Pagamento e Administração de Recursos Humanos.

Tabela 4.6 Módulo 4 Treinamento - Pacote de Software: Folha de Pagamento e Administração de Recursos Humanos.

Tabela 4.7 Módulo 5 Documentação de Treinamento - Pacote de Software: Folha de Pagamento e Administração de Recursos Humanos.

Tabela 4.8 Módulo 6 Serviços Técnicos - Pacote de Software: Folha de Pagamento e Administração de Recursos Humanos.

Tabela 4.9 Módulo 7 Atualização de Versão - Pacote de Software: Folha de Pagamento e Administração de Recursos Humanos.

Tabela 4.10 Módulo 1 Adequação - Pacote de Software: Controle de Ponto Eletrônico..

Tabela 4.11 Módulo 2 Documentação - Pacote de Software: Controle de Ponto Eletrônico......

Tabela 4.12 Módulo 3 Serviços de Manutenção - Pacote de Software: Controle de Ponto Eletrônico.

Tabela 4.13 Módulo 6 Serviços Técnicos - Pacote de Software: Controle de Ponto Eletrônico.

Tabela 4.14 Módulo 7 Atualização de Versão - Pacote de Software: Controle de Ponto Eletrônico..

Tabela 4.15 Módulo 1 Adequação - Pacote de Software: Contabilidade i.................................. 75

Tabela 4.16 Módulo 4 Treinamento - Pacote de Software: Contabilidade i............................... 77

Tabela 4.17 Módulo 6 Serviços Técnicos - Pacote de Software: Contabilidade i....................... 78

Tabela 4.18 Módulo 1 Adequação - Pacote de Software: Contabilidade ii................................. 80

Tabela 4.19 Módulo 2 Documentação - Pacote de Software: Contabilidade ii.......................... $\quad 82$

Tabela 4.20 Módulo 4 Treinamento - Pacote de Software: Contabilidade ii.............................. 83

Tabela 4.21 Módulo 6 Serviços Técnicos - Pacote de Software: Contabilidade ii..................... 84

Tabela 4.22 Módulo 7 Atualização de Versão - Pacote de Software: Contabilidade ii.............. 85

Tabela 4.23 Módulo 1 Adequação - Pacote de Software: Controle de Materiais....................... $\quad 87$ 
Tabela 4.24 Módulo 2 Documentação - Pacote de Software: Controle de Materiais..

Tabela 4.25 Módulo 3 Serviços de Manutençāo - Pacote de Software: Controle de Materiais.

Tabela 4.26 Módulo 4 Treinamento - Pacote de Software: Controle de Materiais.

Tabela 4.27 Módulo 5 Documentaçāo de Treinamento - Pacote de Software: Controle de Materiais..

Tabela 4.28 Módulo 6 Serviços Técnicos - Pacote de Software: Controle de Materiais.. 93

Tabela 4.29 Módulo 1 Adequaçāo - Pacote de Software: Controle de Contas a Pagar.. 94

Tabela 4.30 Módulo 2 Documentação - Pacote de Software: Controle de Contas a Pagar......... 97

Tabela 4.31 Módulo 4 Treinamento - Pacote de Software: Controle de Contas a Pagar............ 98

Tabela 4.32 Módulo 5 Documentação de Treinamento - Pacote de Software: Controle de Contas a Pagar.................................................................................................... 99

Tabela 4.33 Módulo 6 Serviços Técnicos - Pacote de Software: Controle de Contas a Pagar... 100

Tabela 4.34 Módulo 7 Atualização de Versāo - Pacote de Software: Controle de Contas a Pagar. 


\section{LISTA DE QUADROS}

Página

Quadro 2.1 Normas ISO Série 9000 e Documentos da ABNT..................................................... 7

Quadro 2.2 Documentos Complementares da ISO-9000 Relacionados com o Software.............. 7

Quadro 2.3 Definição da Qualidade de Produto de Software......................................................... 8

Quadro 2.4 Subcaracterísticas da Funcionalidade ISO/IEC 9126.............................................. 10

Quadro 2.5 Subcaracterísticas da Usabilidade ISO/IEC 9126................................................ 10

Quadro 2.6 Subcaracterísticas da Confiabilidade ISO/IEC 9126............................................. 10

Quadro 2.7 Subcaracterísticas da Eficiência ISO/IEC 9126................................................... 11

Quadro 2.8 Subcaracterísticas da Manutenibilidade ISO/IEC 9126....................................... 11

Quadro 2.9 Subcaracterísticas da Portabilidade ISO/IEC 9126.................................................. 12

Quadro 2.10 Lista de Questões de Interesse da Pesquisa de Vidal.............................................. 19

Quadro 2.11 Exemplo da Métrica Usada por Vidal: Escolha de Uma Alternativa entre

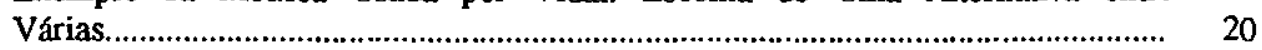

Quadro 2.12 Exemplo da Métrica Usada por Vidal: Classificação de Frases com Escala Variando de Um até Cinco....................................................................................... 21

Quadro 2.13 Lista de Questões de Interesse do CTI................................................................... 25

Quadro 2.14 Exemplo da Métrica Usada no CTI em 1996.......................................................... 26

Quadro 2.15 Lista de Questōes de Interesse da Pesquisa de Belchior............................................ 28

Quadro 2.16 Exemplo da Métrica Usada por Belchior................................................................ $\quad 30$

Quadro 2.17 Tabela de Peso Usada por Belchior....................................................................... $\quad 30$

Quadro 2.18 Relacionamento das Características de Qualidade de Produto de Software............... 33

Quadro 3.1 Lista de Questōes de Interesse a Serem Respondidas pela Pesquisa......................... 36

Quadro 3.2 Questões de Interesse Adicionais......................................................................... 37

Quadro 3.3 Módulo 1: Adequação do Pacote de Software ao Ambiente Empresarial................. 46

Quadro 3.4 Módulo 2: Qualidade da Documentação................................................................ 47

Quadro 3.5 Módulo 3: Serviços de Manutenção ......................................................................... 48

Quadro 3.6 Módulo 4: Treinamento Realizado.................................................................... 49

Quadro 3.7 Módulo 5: Documentação de Treinamento.............................................................. 49

Quadro 3.8 Módulo 6: Serviços Técnicos Prestados................................................................ 50

Quadro 3.9 Modulo 7: Atualização de Versão do Pacote de Software......................................... 50 


\section{Capítulo 1}

\section{INTRODUÇÃO}

\subsection{Contexto e Motivação}

O software tornou-se parte de nossa vida diária, criando novas formas de convivência entre as pessoas, organizações e sociedade. E isso promoveu um crescimento considerável na oferta de pacotes de software de sistemas de informação. Essa oferta e sua constante evoluçāo dificultam a seleção de um determinado pacote de software. O número de opções disponíveis no mercado que aparentemente podem solucionar um problema específico de uma empresa, nos diversos níveis de decisão da mesma, é cada vez maior. Outra questão que se coloca necessária é: "Como saber se um pacote de software que já foi selecionado e está sendo utilizado é efetivamente adequado para uma determinada empresa ?'

A necessidade de realizar a avaliação da qualidade de produto de software é evidente para a empresa, pois o pacote de software que está sendo utilizado ou vai ser adquirido poderá influenciar o seu negócio através do serviço prestado para o seu cliente. A avaliação permite obter um panorama da situação em que se encontra o parque de software instalado e facilita a tomada de decisões.

A partir da década de 90, o Brasil começou a intensificar a busca pela qualidade. A qualidade de produtos e de serviços prestados passou a ser importante e năo somente a venda de produtos e serviços baratos. A busca pela qualidade ditou algumas das novas regras do mercado brasileiro que são orientadas à produção de produtos e serviços com qualidade, com entrega no prazo determinado, com atendimento correto, inclusive na assistência pós-venda, e ao menor custo [WER94]. Hoje, uma forte corrente no marketing e nos negocios sustenta que serviços e produtos de alta qualidade ocupam posição competitiva privilegiada no mercado [URD93]. Isto mostra que a 
preocupação com a qualidade de um produto de software e serviços oferecidos pós-venda (por exemplo: implantação, manutenção, suporte técnico) é imprescindível em nossos dias.

Vidal [VID90] realizou uma pesquisa entre os usuários de microcomputadores em pequenas e médias empresas no Brasil, na qual procurou conhecer como a seleção de pacotes de software era realizada. Para isto, utilizou alguns fatores de qualidade de software. O resultado desta pesquisa forneceu elementos para a avaliação de pacotes de software administrativos (exemplos: desempenho, documentação, atendimento às necessidades, facilidade de uso, facilidade de aprendizado, flexibilidade, custo, reputação do fornecedor, suporte do fornecedor, integração e compatibilidade), e permitiu mostrar as principais características do processo de informatização das empresas.

Uma das dificuldades encontradas por Vidal, à época de sua pesquisa, foi a falta de padrōes de medida, fato este que contribuia para a pouca consideração e para a grande carga de subjetividade que impregnava, via de regra, a atenção dada ao problema de qualidade de software.

Outro trabalho nessa perspectiva é o trabalho de Belchior [BEL92] que publicou em 1992 uma pesquisa de campo realizada em instituiçōes financeiras do Brasil onde identificou os atributos de qualidade de software para a área financeira. O questionário foi aplicado especificamente para softwares financeiros, mas também poderia ser aplicado para outros ambientes para verificar a relevância das características de qualidade estudadas ao considerar-se softwares que abrangem outras áreas.

No mundo, o faturamento anual do setor do software vem sendo multiplicado por dez a cada década. Em 1970, era um bilhão de dólares, em 1980, eram dez bilhões de dólares; e em 1990, cem bilhōes de dolares e prevê-se um trilhão de dólares para o ano 2000, especialmente em face da nova revolução do software provocada pela Internet. Isso coloca o software como o grande negócio do presente e do futuro [WEB97].

A abertura do mercado nacional para as importações impulsionou a busca pela qualidade. Não basta mais vender barato, as novas regras de mercado são orientadas à produção de bens e serviços com qualidade, com prazo determinado de entrega, com atendimento correto e também ao menor custo. A década de 90 é certamente a década da qualidade de software, pois a crescente 
dependência da sociedade em relação ao software intensificou a demanda pela qualidade de software ([KAN94], [KHO94], [KIT96]).

Diante desta situação, ocorreu um processo de mudança no qual as empresas, para garantir o mercado para exportação, começaram a produzir seus produtos de acordo com as exigências de certificação de qualidade (que a partir de 1987 passaram a ser conhecidas com a divulgação da ISO9000) e com isto vem crescendo significativamente a aplicação dos sistemas e padrões da série ISO 9000 no mundo.

Em 1991, a ISO (International Organization for Standardization), um grupo internacional de normalização localizado em Genebra, Suíça, uniu-se à IEC (International Electrotechnical Comission) e criaram a norma internacional ISO/IEC-9126, onde foram estabelecidas as características básicas de qualidade de produto de software. A ISO/IEC 9126 [ISO/IEC-9126] define a qualidade de produto de software através de 6 características básicas: Funcionalidade (funções oferecidas ao usuário que atendem as suas necessidades), Confiabilidade (tolerância a falha), Usabilidade (facilidade de uso do software), Eficiência (desempenho do software em relação a tempo e recursos), Manutenibilidade (facilidade de modificar o software) e Portabilidade (facilidade de mudar de ambiente).

A ASSESPRO (Associação das Empresas Brasileiras de Software e Serviços de Informática), através do CTI (Fundação Centro Tecnológico para Informática), utiliza estas características de qualidade para atribuir o prêmio "Melhor Software do Ano - ASSESPRO". Esta atividade é realizada dentro do Programa de Qualidade e Produtividade em Software - PQPS [CTI94]. A avaliação do CTI é baseada em um questionário (checklist) que contribui para a avaliação de pacotes de software com o objetivo de avaliar e comparar os produtos de software para a indicação de compra. O questionário é respondido por pessoas que receberam conhecimento técnico e treinamento e a avaliação é realizada em laboratório.

Como pode-se notar, as pesquisas empíricas realizadas e citadas acima possuem em comum o mesmo tema, ou seja, a ênfase nos elementos e características de qualidade de produto de software para a realização de avaliaçōes, apesar de seus objetivos serem diferentes. 


\subsection{Objetivos}

As pessoas que trabalham em empresas, na maioria das vezes, não sāo técnicas na área de engenharia de software, com pouca experiência em processamento de dados, mas possuem o conhecimento de suas funções, dos processos da empresa e de suas necessidades. Também existem algumas questões que são importantes de serem avaliadas em um contexto empresarial, por exemplo, as relativas ao treinamento realizado, a satisfaçāo do usuário com a empresa fornecedora do software através de serviços de manutenção e técnicos prestados.

O objetivo deste trabalho é a proposição de um método baseado nas características de qualidade de produto para avaliação de pacotes de software na área de sistemas de informação em operação (por exemplo: o sistema de ponto eletrônico, o sistema de contabilidade, o sistema de recursos humanos, controle de materiais, sistema de contas a pagar). Cabe salientar que tem por objetivo também avaliar a qualidade dos serviços oferecidos pos-venda pela empresa fornecedora do pacote de software (por exemplo: o treinamento realizado, serviços de manutenção, serviços técnicos prestados). O resultado deste trabalho dará subsídios na obtenção de dados para o apoio de tomada de decisão gerencial, pois será conhecida a situação em que se encontram os pacotes de softwares quanto a sua adequação na empresa, manual do usuário, treinamento realizado, documentação de treinamento, atualização de versão do pacote de software, serviços técnicos, serviços de manutenção.

Como um estudo de caso este método será aplicado na empresa Ceterp S/A onde encontramse em operação vários pacotes de softwares administrativos e financeiros que foram comprados através de edital Assim, os resultados deste trabalho serão de uso imediato e de grande importância à própria Ceterp S/A que terá um quadro da adequação do seu parque de software instalado e a criação de um histórico de dados para a obtenção de informações que dará apoio ao processo de tomada de decisão gerencial quanto aos pacotes de softwares.

Para orientação do desenvolvimento deste trabalho será utilizado o método Goal/Question/Metric [BAS94], desenvolvido especificamente para pesquisas empíricas em engenharia de software e que também servirá de ferramenta para estabelecer o método de avaliação. 


\subsection{Organização}

Este trabalho está organizado em cinco capítulos e um anexo. O Capítulo 1 apresenta o contexto em que está inserido este trabalho e as bases que motivaram a realização desta proposta de trabalho.

O Capítulo 2 apresenta uma revisão bibliografica da qualidade de produto de software, com a apresentação da Norma ISO/IEC 9126 [ISO/IEC-9126], e do método GQM que servirá como ferramenta base para o desenvolvimento deste trabalho. Também apresenta-se a descrição de três modelos de qualidade de produto de software encontrados na literatura.

O Capítulo 3 usa o método GQM para apresentar a proposta deste trabalho definindo o objetivo desejado e disponibiliza como resultado da aplicação deste método um questionário sobre a avaliação da qualidade de pacotes de software na área de sistemas de informação.

O Capítulo 4 apresenta um estudo de caso realizado em uma empresa, para isto utiliza-se de uma ferramenta de orientação, o método GQM, que serve de apoio para o desenvolvimento de pesquisas de campo realizadas na área de engenharia de software.

O Capítulo 5 apresenta as conclusōes sobre o trabalho realizado e o Anexo 1 apresenta o questionário que serviu para a avaliação da qualidade de pacotes de software na área de sistemas de informação submetidos aos usuários da Ceterp S/A. 


\section{Capítulo 2}

\section{Modelos de Qualidade de Produto de Software}

\subsection{Considerações Iniciais}

Uma vez que este trabalho pretende apresentar um método de avaliação da qualidade de pacotes de software na área de sistemas de informação, neste capítulo comenta-se sobre qualidade de produto de software e é apresentada a norma de qualidade de produto de software da ISO/IEC 9126, e o método Goa/Question/Metric (GQM) que servirá para a avaliação de qualidade de produto de software na área de sistemas de informação. São também mostrados os modelos de qualidade de produto de software que foram utilizados empiricamente (modelo de Vidal, método do CTI, modelo de Belchior) e que serviram de base para o método proposto neste trabalho. Cabe salientar que esses modelos foram colocados de uma forma padronizada, seguindo os passos do método GQM que fornece um mecanismo que orienta a definição de metas a serem alcançadas e usa essas metas para gerar um conjunto de questões.

\subsubsection{A Qualidade de Produto de Software}

As normas ISO série 9000 (ISO-9000) representam o consenso de vários países, entre os quais o Brasil, através da ABNT - Associação Brasileira de Normas Técnicas, para a normalização da qualidade. Elas orientam na busca da melhoria dos níveis de qualidade para produtos, serviços e relacionamento cliente/fornecedor, através de diretrizes para a implantação de sistemas de qualidade 
nas empresas e com isto a legislação de software, incluindo regime jurídico e questões de direito comercial, vem se consolidando no país e no mundo. Os documentos das normas ISO série 9000 e os documentos oficializados pela ABNT são apresentados no Quadro 2.1.

Quadro 2.1 Normas ISO Série 9000 e Documentos da ABNT

\begin{tabular}{|l|l|l|}
\hline \multicolumn{1}{|c|}{ ISO } & \multicolumn{1}{|c|}{ ABNT } & \multicolumn{1}{c|}{ Descrição do Documento } \\
\hline $\begin{array}{l}\text { ISO-9000 } \\
\text { [ISO-9000] }\end{array}$ & NBR-19000 & $\begin{array}{l}\text { Normas de Gestão da Qualidade e Garantia da Qualidade. } \\
\text { Diretrizes para seleção (da Norma mais adequada ao caso da } \\
\text { empresa) e uso. }\end{array}$ \\
\hline $\begin{array}{l}\text { ISO-9001: 1994 } \\
\text { [ISO-9001] }\end{array}$ & NBR-19001: 1994 & $\begin{array}{l}\text { Sistemas da Qualidade - Modelo para Garantia da Qualidade em } \\
\text { Projeto, Desenvolvimento, Produção, Instalação e Assistência } \\
\text { Técnica. }\end{array}$ \\
\hline $\begin{array}{l}\text { ISO-9002: 1994 } \\
\text { [ISO-9002] }\end{array}$ & NBR-19002:1994 & $\begin{array}{l}\text { Sistemas de Qualidade - Modelo para Garantia da Qualidade em } \\
\text { Produção e Instalação e Serviços Associados. }\end{array}$ \\
\hline $\begin{array}{l}\text { ISO-9003 } \\
\text { [ISO-9003] }\end{array}$ & NBR-19003 & $\begin{array}{l}\text { Sistemas de Qualidade - Modelo para Garantia da Qualidade em } \\
\text { Inspeção e Ensaios Finais. }\end{array}$ \\
\hline $\begin{array}{l}\text { ISO-9004 } \\
\text { [ISO-9004] }\end{array}$ & NBR-I9004 & $\begin{array}{l}\text { Gestão da Qualidade e Elementos do Sistema da Qualidade - } \\
\text { Diretrizes. }\end{array}$ \\
\hline
\end{tabular}

Com relação ao software, a série ISO-9000 apresenta dois documentos complementares relacionados no Quadro 2.2 abaixo, porque reconheceu que os processos de software são diferentes daqueles da maioria dos outros tipos de indústrias.

Quadro 2.2 Documentos Complementares da ISO-9000 Relacionados com o Software

\begin{tabular}{|l|l|l|}
\hline \multicolumn{1}{|c|}{ ISO } & \multicolumn{1}{|c|}{ ABNT } & \multicolumn{1}{|c|}{ Descrição do Documento } \\
\hline $\begin{array}{l}\text { ISO-9000-3: 1991 } \\
\text { [ISO-9000-3] }\end{array}$ & NBR ISO 9000-3 & $\begin{array}{l}\text { Trata da qualidade dos Processos. Esta norma estabelece } \\
\text { diretrizes para a aplicação da ISO 9001 ao } \\
\text { desenvolvimento, fornecimento e manutenção de software. }\end{array}$ \\
\hline $\begin{array}{l}\text { ISO/IEC-9126: } \\
1991 \\
\text { [ISO/IEC-9126] }\end{array}$ & $\begin{array}{l}\text { NBR 13596 } \\
\text { [NBR-13596] }\end{array}$ & $\begin{array}{l}\text { Trata da Qualidade do produto de software. Trata da } \\
\text { avaliação da qualidade de produto de software com a } \\
\text { definição de características de qualidade e guias para o seu } \\
\text { uso. }\end{array}$ \\
\hline
\end{tabular}

A qualidade de software é um termo abrangente, que envolve tanto a qualidade de processo de desenvolvimento de software quanto a qualidade do produto final A qualidade de produto de software 
é um objetivo do processo de desenvolvimento. Raras são as ocasiões em que qualidade pode ser incorporada ao produto de forma não consciente ou, então, apos o processo de desenvolvimento ter terminado. Assim, ao desenvolver-se um produto, deve-se sempre ter em perspectiva as características de qualidade previamente estabelecidas que se quer alcançar. Se o desenvolvimento de software preocupar-se com as características de qualidade, pode-se dizer que o produto deverá apresentar essas características.

Vários modelos têm contribuído para a elaboração de modelos e normas para a avaliação e melhoria de qualidade de processo de desenvolvimento de software, alguns exemplos desses modelos são: o Capability Maturity Model [HUM89], [RAD85] do Instituto de Engenharia de Software (SEI), o Paradigma Melhoramento de Qualidade/Fator de Experiência Organizacional [BAS85], [BAS92], Guidelines for the Application of ISO-9001 to the Development, Supply and Maintenance of Software [ISO-9000-3], o Plan-Do-Check-Act [DEM86], Software Process Improvement and Capability Determination [SPI95].

Não se perdendo a visão de sua integração, os estudos e desenvolvimentos das abordagens de avaliação de qualidade de processo e qualidade de produto podem ser feitos separadamente [CTI96], [TSU97].

Neste trabalho dar-se á ênfase à qualidade de produto de software. O conceito de qualidade de produto de software é complexo, porque não existe uma idéia única que a define pois depende do ponto de vista de pessoas e do contexto. Existem várias definições na literatura que estão descritas no Quadro 2.3 abaixo.

Quadro 2.3 Definição de Qualidade de Produto de Software

\begin{tabular}{|l|c|}
\hline \multicolumn{1}{|c|}{ Conceito } & Referência \\
\hline $\begin{array}{l}\text { Qualidade de software é um conjunto de propriedades a serem satisfeitas, em } \\
\text { determinado grau, de modo que o software satisfaça as necessidades de seus } \\
\text { usuários. }\end{array}$ & $\begin{array}{c}\text { Rocha } \\
\text { [ROC87] }\end{array}$ \\
\hline $\begin{array}{l}\text { Qualidade é a totalidade de características de um produto de software que lhe } \\
\text { confere a capacidade de satisfazer as necessidades explícitas e implícitas. As } \\
\text { necessidades explić́tas são caracterizadas pelos documentos de especificação de } \\
\text { requisitos e manual do usuário e as necessidades implícitas podem ser caracterizados } \\
\text { [ISOmo requisitos necessários, mas não definidos nos documentos de software. }\end{array}$ \\
\hline
\end{tabular}


(continuação)

Quadro 2.3 Definição de Qualidade de Produto de Software

\begin{tabular}{|l|c|}
\hline \multicolumn{1}{|c|}{ Conceito } & Referência \\
\hline $\begin{array}{l}\text { Conformidade aos requisitos funcionais e de desempenho explicitamente declarados, } \\
\text { aos padrões de desenvolvimento claramente documentados e as características } \\
\text { implícitas que são esperadas pelos profissionais que desenvolvem software. }\end{array}$ & $\begin{array}{c}\text { Pressman } \\
\text { [PRE94] }\end{array}$ \\
\hline Qualidade de software é a conformidade as expectativas e aos requisitos do usuário. & Kan [KAN94] \\
\hline
\end{tabular}

Vários trabalhos e esforços têm contribuído para a elaboração de modelos e normas para a avaliação de qualidade de produto de software, alguns exemplos deles são: Modelo de Shin [SHI96], Norma ISO/IEC 9126 [ISO/IEC-9126], Modelo de Vidal [VID90], Modelo de FURPS [GRA87], Modelo de McCall [MCC77]. Na Seção 2.2 serão descritos 3 modelos de qualidade de produto de software (Modelo de Vidal, Método do CTI, Modelo de Belchior). A seguir é descrita a Norma da ISO/IEC 9126.

Norma ISO/IEC 9126 [ISO/IEC-9126]

A norma ISO/IEC 9126 , publicada em 1991 originou-se de vários outros modelos apresentados desde 1976, por McCall [MCC77], até os modelos mais recentes como o modelo de FURPS [GRA87]. A ISO/IEC 9126 define seis características de qualidade de software que servem para a avaliação do produto de software. A ISO/IEC 9126 foi traduzida para o português dando origem à Norma NBR 13596 [NBR-13596] da ABNT. A seguir são descritas as principais características de qualidade extraídas da Norma NBR 13596.

Funcionalidade - Evidencia que o conjunto de funções atendem d̀s necessidades explícitas e implícitas para a finalidade a que se destina o produto. A funcionalidade mede as capacidades do software, isto é, o conjunto de funçōes oferecidas ao usuário, que satisfaça suas necessidades. Suas subcaracterísticas são: adequação, acurácia, interoperabilidade, conformidade e segurança de acesso, apresentadas no Quadro 2-4. 


\section{Quadro 2-4 Subcaracterísticas da Funcionalidade ISO/IEC 9126}

\begin{tabular}{|l|l|}
\hline \multicolumn{2}{|c|}{ Subcaracterísticas da Funcionalidade } \\
\hline Adequação & Presença de conjunto de funções e sua apropriação para as tarefas. \\
\hline Acurácia & Geração de resultados ou efeitôs corretos. \\
\hline Interoperabilidade & Capacidade de interagir com outros sistemas. \\
\hline Conformidade & Estar de acordo com normas, convenções ou regulamentações. \\
\hline Segurança de Acesso & Capacidade de evitar o acesso não autorizado a programas e dados. \\
\hline
\end{tabular}

Usabilidade - Evidencia a facilidade para a utilização do software. Essa característica avalia o esforço necessário ao uso do software e ao seu aprendizado (treinamento). É uma característica determinada, normalmente, por fatores como interface com o usuário, documentação clara e material de treinamento adequado. Suas subcaracterísticas são: operacionalidade, inteligibilidade, apreensibilidade, apresentadas no Quadro 2.5.

Quadro 2-5 Subcaracterísticas da Usabilidade ISO/IEC 9126

\begin{tabular}{|l|l|}
\hline \multicolumn{2}{|c|}{ Subcaracterísticas da Usabilidade } \\
\hline Operacionalidade & Facilidade de operar e controlar a operação. \\
\hline Inteligibilidade & Facilidade de entendimento dos conceitos utilizados. \\
\hline Apreensibilidade & Facilidade de aprendizado. \\
\hline
\end{tabular}

Confiabilidade - Evidencia que o desempenho se mantém ao longo do tempo e em condições estabelecidas. Essa característica refere-se à capacidade do software manter seu nível de desempenho, sob condições estabelecidas, por um determinado período de tempo. Suas subcaracterísticas são: recuperabilidade, tolerância a falhas, maturidade, apresentadas no Quadro 2-6.

Quadro 2-6 Subcaracterísticas da Confiabilidade ISO/IEC 9126

\begin{tabular}{|l|l|}
\hline \multicolumn{2}{|c|}{ Subcaracterísticas da Confiabilidade } \\
\hline Recuperabilidade & Capacidade de se restabelecer e restaurar dados após falha. \\
\hline Tolerância a Falhas & Manter nível de desempenho em caso de falha. \\
\hline Maturidade & Freqüiência de falhas. \\
\hline
\end{tabular}


Eficiência - Evidencia que os recursos e os tempos envolvidos são compatíveis com o nível de desempenho requerido para o produto. A característica eficiência refere-se a desempenho, tempo de resposta e uso eficaz dos recursos do sistema. É medido pela relação entre o nível de desempenho do software e a quantidade de recursos usadas, sob condições estabelecidas. Suas subcaracterísticas são: comportamento em relação ao tempo, comportamento em relação aos recursos, apresentadas no Quadro 2-7.

Quadro 2-7 Subcaracterísticas da Eficiência ISO/IEC 9126

\begin{tabular}{|l|l|}
\hline \multicolumn{2}{|c|}{ Subcaracterísticas da Eficiência } \\
\hline Comportamento em Relação ao Tempo & Tempo de resposta, de processamento. \\
\hline Comportamento em Relação aos Recursos & Quantidade de recursos utilizados. \\
\hline
\end{tabular}

Manutenibilidade - Evidencia que há facilidade para correçōes, atualizações e alterações. A avaliação pode ser feita através da análise da facilidade/rapidez de manutenção, custo das manutenções, tempo médio entre falhas, tempo médio de reparo, entre outros. Suas subcaracterísticas são: analisabilidade, testabilidade, estabilidade, modificabilidade, apresentadas no Quadro 2-8.

\section{Quadro 2-8 Subcaracterísticas da Manutenibilidade ISO/IEC 9126}

\begin{tabular}{|l|l|}
\hline \multicolumn{2}{|c|}{ Subcaracterísticas da Manutenibilidade } \\
\hline Analisabilidade & Facilidade de diagnosticar deficiências e causas de falhas. \\
\hline Testabilidade & Facilidade de ser testado. \\
\hline Estabilidade & Ausência de riscos de efeitos inesperados. \\
\hline Modificabilidade & Facilidade de modificação e remoção de defeitos. \\
\hline
\end{tabular}

Portabilidade - Evidencia que é possível utilizar o produto em diversas plataformas com pequeno esforço de adaptação. Essa característica avalia basicamente o esforço necessário para que se faça a transferência do software para diferentes sistemas ou plataformas. Suas subcaracterísticas são: adaptabilidade, capacidade para ser instalado, conformidade a padrões de portabilidade, capacidade para substituir e estão apresentadas no Quadro 2-9. 
Quadro 2-9 Subcaracterísticas da Portabilidade ISO/IEC 9126

\begin{tabular}{|l|l|}
\hline \multicolumn{2}{|c|}{ Subcaracterísticas da Portabilidade } \\
\hline Adaptabilidade & Capacidade de ser adaptado a ambientes diferentes. \\
\hline Capacidade para ser instalado & Facilidade de instalação. \\
\hline Conformidade & Acordo com padrões ou convençōes de portabilidade. \\
\hline Capacidade para substituir & Substituir outro software \\
\hline
\end{tabular}

A seguir é descrito o método GQM que serve de base para o desenvolvimento do presente trabalho e para apresentação de alguns trabalhos na área de qualidade de software relacionados a este trabalho.

\subsubsection{O Método Goal/Question/Metric - GQM}

O método Goal/QuestionMetric [BAS84] apóia a realização de pesquisas empíricas na área de engenharia de software e por isso foi utilizado em vários projetos de pesquisa de engenharia de software ([ROM90], [SHE90], [ROM87], [BAS90], [BAS86], [BAS88], [ROM89], [GAl91], [SAN94], [SOL95]) e aplicado em várias organizações, por exemplo: NASA, Hewlett Packard, Motorola, Coopers \& Lybrand. O método GQM é constituṛ́o de seis passos básicos apresentados na Figura 2.1.

Figura 2.1 Passos do Método GQM

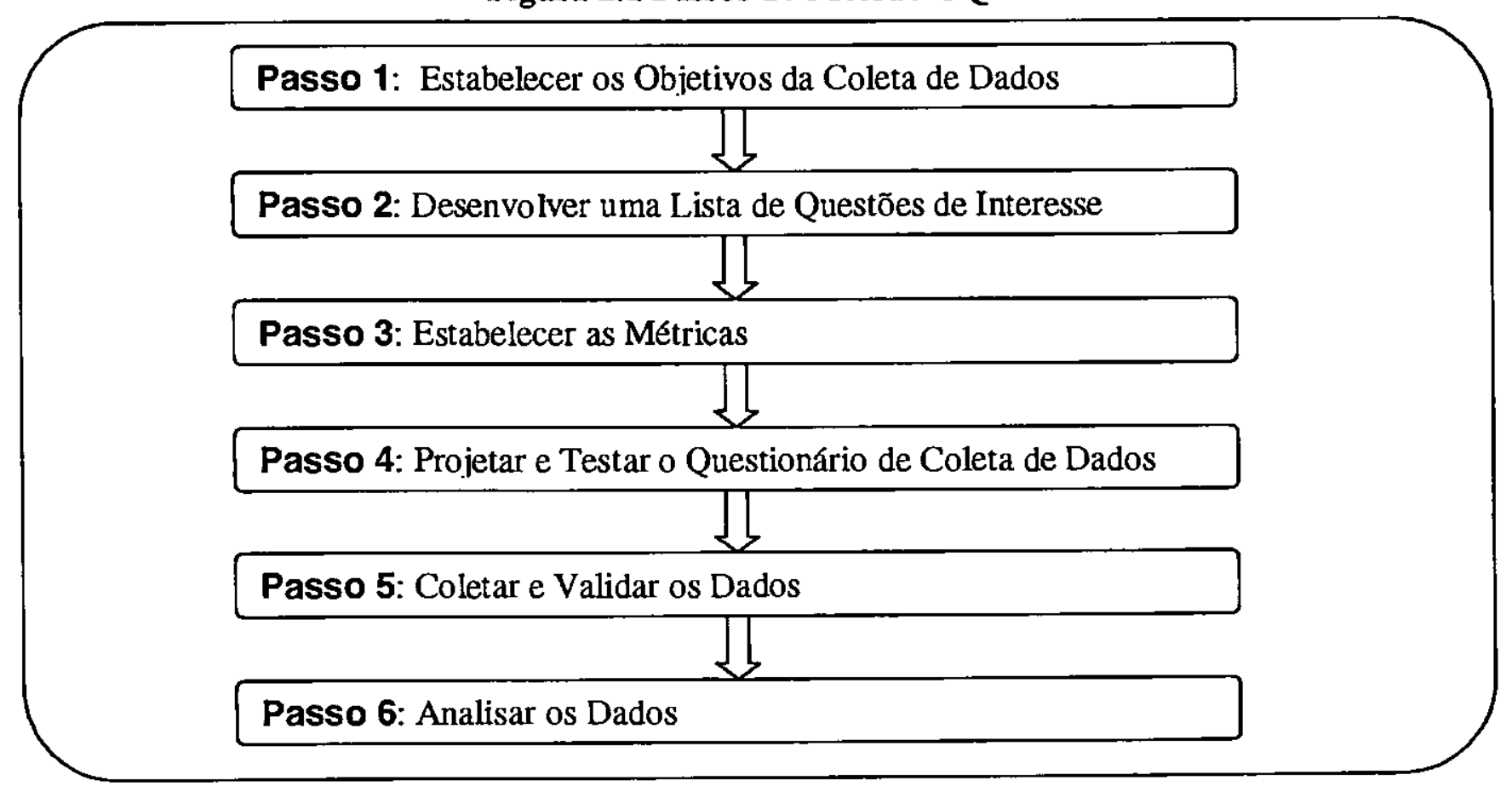


Esse método fornece um mecanismo que orienta a determinaçāo dos objetivos de interesse da análise e o refinamento de cada objetivo em um conjunto de questōes a serem respondidas. Essas questões são quantificadas e definem o conjunto específico de dados a serem coletados e validados para a análise da meta.

O método GQM é apresentado na forma de uma estrutura hierárquica [BAS91], que utiliza a técnica top-down para o seu desenvolvimento (Figura 2.2), porque há muitas características observáveis no software, cuja forma de uso e de interpretação só se tornam claras a partir da definiçãa de modelos e objetivos apropriados para o contexto. Os 6 passos básicos do método GQM são descritos a seguir, conforme Sanches [SAN94].

Figura 2.2 Estrutura Hierárquica do Método GQM

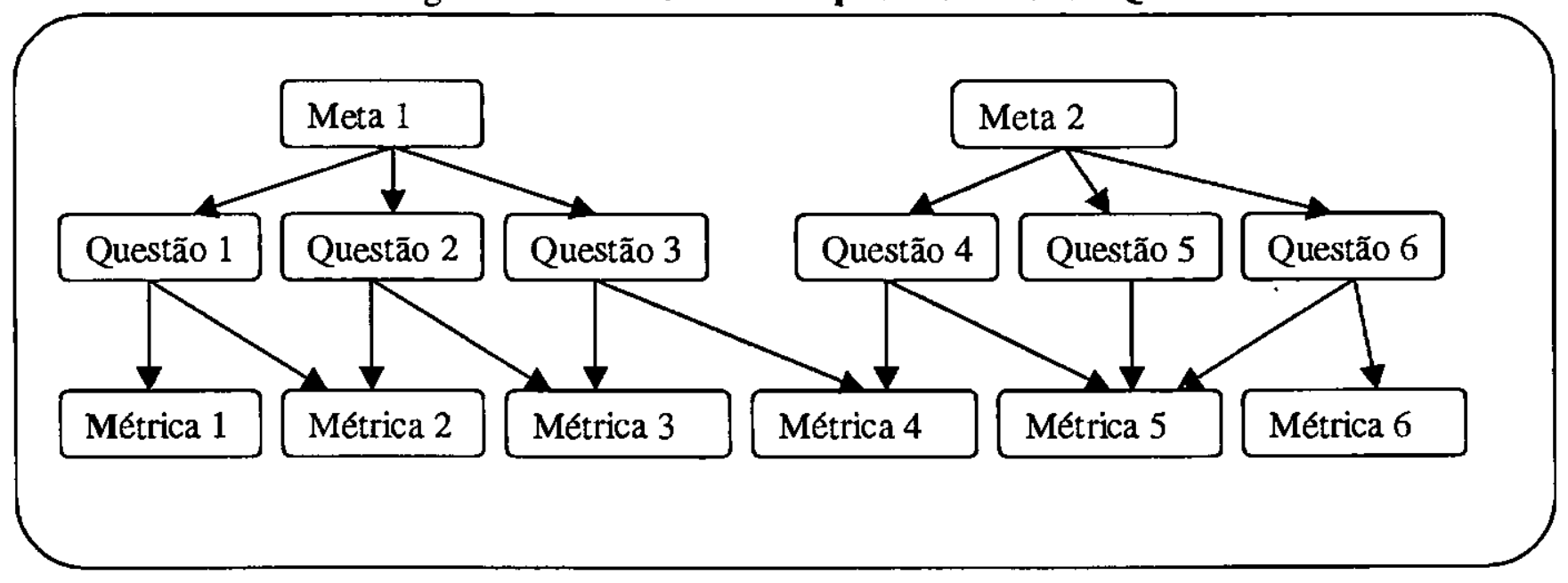

\section{Passo 1: Estabelecer os Objetivos da Coleta de Dados}

O primeiro passo focaliza o trabalho a ser realizado, ou seja, a definição da meta. A meta é definida em termos de vários fatores: Objeto de Estudo (qual o objeto que está sendo analisado ?), Propósito (qual o propósito da análise ?), Perspectiva (qual o ponto de vista da qual a análise está sendo realizada ?), Foco da Qualidade (quais características do objeto ?), Ambiente (qual o contexto da análise ?). Pode-se em uma determinada pesquisa definir uma ou mais metas.

A meta, segundo Basili [BAS94], possui 3 coordenadas conforme ilustrada na Figura 2.3. 
Figura 2.3 Coordenadas da Meta do Método GQM

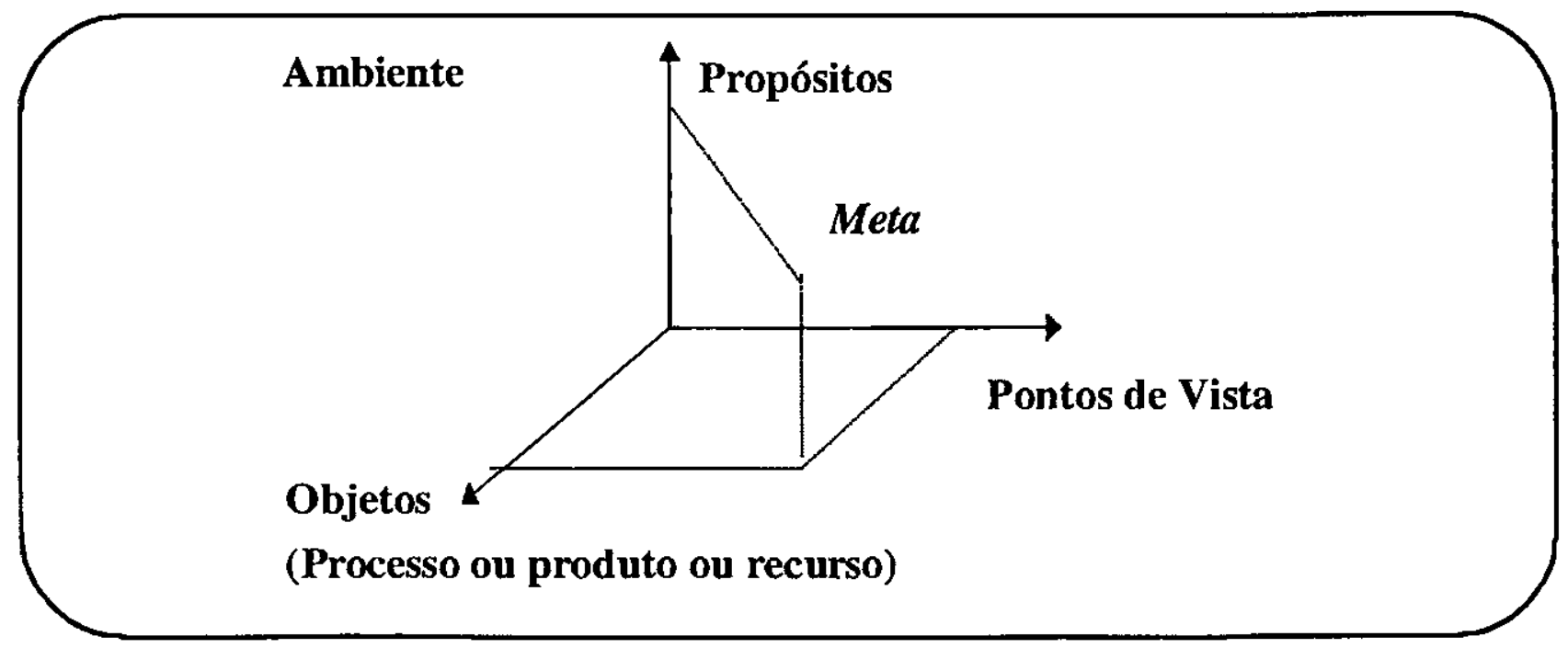

Se as metas desejadas não forem estabelecidas ou não estiverem bem definidas, corre-se o risco de coletar dados que não estejam relacionados com essas metas, dados sem significado para o objetivo da pesquisa e como conseqüência não conseguir atingir um resultado.

O objeto de estudo pode ser um processo, ou um produto, ou um recurso. Um processo está relacionado com as atividades de software normalmente associadas com o tempo, por exemplo: as atividades de especificação, projeto, teste e entrevista. Produtos são documentos e entregas que são produzidos durante o ciclo de vida do sistema, por exemplo: especificações, projetos, programas. Recursos são itens, usados pelos processos para produzir suas saídas, por exemplo: pessoal, hardware, software, espaço de escritorio. O propósito pode ser: determinar, entender, melhorar, caracterizar, avaliar, prever, motivar ou controlar algum aspecto de qualidade do objeto do estudo. Determina-se o porquê do projeto estar sendo analisado. A perspectiva identifica a quem interessa os resultados da pesquisa; neste item estabelece-se o ponto de vista da análise. Exemplo: ponto de vista do usuário, cliente, gerente, desenvolvedor, organização. $O$ foco da qualidade deve identificar as propriedades ou qualidades do objeto a ser analisado. $\mathrm{O}$ ambiente fornece o contexto para as interpretações dos resultados da análise. 


\section{Passo 2: Desenvolver uma Lista de Questões de Interesse}

Uma vez que as metas do estudo foram estabelecidas, elas devem ser usadas para desenvolver uma lista de questões de interesse para ser respondidas pelo estudo. As questões de interesse definem os parâmetros e as categorias que permitem uma análise quantitativa dos dados. Cada meta resultará na geração de várias questões de interesse.

As questões devem permitir uma caracterização do objeto (processo, produto ou recurso) de pesquisa e dos aspectos de qualidade de acordo com o ponto de vista selecionado. As questões relacionadas com o produto são formuladas com o proposito de definir o produto, por exemplo: atributos físicos, custos, mudanças e defeitos, contexto do usuário, definir a perspectiva de qualidade de interesse (Exemplos: funcionalidade, confiabilidade, amigabilidade). As questões relacionadas com o processo são formuladas com o propósito de: definir o produto, conformidade com o processo, conformidade com o domínio, definir a perspectiva de qualidade de interesse.

As metas resultarão na geração de várias questões diferentes de interesse e questões de interesse formam uma ponte entre determinar as metas do estudo e as medidas que devem ser usadas no estudo, conforme já ilustrado na Figura 2.2. Elas permitem aos investigadores determinar as quantidades que precisam ser medidas e os aspectos das metas que podem ser medidos.

A omissão de questões de interesse tem como conseqüência a falta de uma base quantitativa para responder as metas dos estudos. Com efeito, se as questões de interesse nāo podem ser formuladas é porque as metas não foram bem definidas. Definida a lista de questões de interesse o próximo passo é estabelecer as métricas.

\section{Passo 3: Estabelecer as Métricas}

Neste passo é construído o método de categorização para quantificar as questōes levantadas no passo anterior. $\mathrm{O}$ Passo 3 coloca como cada questão será avaliada, para que se possa saber quais os dados que devem ser coletados. 
Cada questão geralmente induz a um esquema de categorização. É importante ressaltar que cada medida necessita ser vista segundo a perspectiva apropriada. As métricas podem ser objetivas e subjetivas e também podem ser diretas e indiretas.

As métricas objetivas são aquelas que dependem somente do objeto que está sendo medido e não do ponto de vista da análise, por exemplo: número de versões do documento, horas do pessoal gasto em determinada tarefa, tamanho de um programa, etc.

As métricas subjetivas sāo aquelas que dependem do objeto que está sendo medido e do ponto de vista do qual está sendo analisado, por exemplo: entendimento de um texto, nível de satisfação do usuário, etc.

Se não for definido um método de categorização de dados antes da coleta, pode ser que mais tarde, eles não possam ser identificados, quando alguma categoria em particular for fixada.

\section{Passo 4: Projetar e Testar o Questionário de Coleta de Dados}

Depois de estabelecidas as métricas, o questionário de dados é usado para proporcionar uma cópia permanente dos dados e reforçar a memoria tanto do entrevistado e do entrevistador. A tarefa de projetar o questionário de coleta de dados foi uma das partes mais difícies dos estudos conduzidos pelo SEL (Software Engineering Laboratory) da NASA, principalmente porque os questionários representam um compromisso entre dois objetivos que são conflitantes [ BAS84]. Existe por parte do pesquisador o desejo de coletar um conjunto de dados completo e detalhado que conflitará com as necessidades de minimizar o tempo de esforço envolvido em fornecer esse conjunto de dados. $\mathrm{O}$ primeiro objetivo conflitante permite a criação de questionários detalhados e extensos que requerem muito tempo para o seu preenchimento e o segundo objetivo conflitante referente ao tempo requer um questionário curto, por exemplo, o uso de questão de múltipla escolha.

A validação do questionário consiste em verificar se realmente está medindo aquilo que pensase estar medindo. Se necessário, as alterações no questionário de coleta de dados devem ser efetuadas antes que a coleta de dados comece, para isto um projeto piloto é muito importante, pois várias iterações do projeto e períodos de teste são geralmente necessários antes que se passe para o passo 
seguinte. O projeto piloto envolve a participação de fornecedores de dados (entrevistados) no processo de desenvolvimento do questionário, porque as queixas relacionadas com o entendimento por aqueles que devem responder o questionário são resolvidas mais cedo, antes da coleta de dados começar.

\section{Passo 5: Coletar e Validar os Dados}

Os dados são coletados através do preenchimento do questionário desenvolvido na etapa anterior.

A validaçāo consiste em verificar os questionários quanto à não ocorrência de erros, consistência e completitude. Ela é baseada nas entrevistas com aquelas pessoas que fornecem os dados de acordo com as métricas.

A coleta de dados pode ser necessária:

- somente uma vez

- periodicamente

- por eventos

- orientada a processo

Em primeiro lugar, para cada métrica é decidido se a métrica pode ser coletada automaticamente por uma ferramenta disponível ou se ela tem de ser coletada manualmente e quem proporcionam os dados.

A coleta e a validação dos dados deverá ocorrer concorrentemente pois os problemas encontrados seriam resolvidos junto com o fornecedor de dados. A análise de dados da Software Engeneering Laboratory (SEL) mostra que sem a validação é possível que ocorra a inexatidão dos dados na ordem de 50\% [BAS84]. 


\section{Passo 6: Analisar os Dados}

O último passo é analisar e interpretar os dados coletados no contexto das questões colocadas no Passo 2. A técnica bottom-up apoia a interpretaçāo dos dados que foram coletados no contexto das metas. Os dados coletados são analisados e processados graficamente e apresentados para um grupo de pessoas que representam o ponto de vista da meta correspondente e para pessoas envolvidas na coleta de dados incluindo os fornecedores de dados. Os resultados são conclusøes e sugestões de melhoria.

\subsection{Modelos de Qualidade de Produto de Software}

\subsubsection{Modelo de Vidal}

Vidal [VID90] propôs um modelo de qualidade de produto de software baseado nos fatores de qualidade de software propostos por McCall [MCC79] e em outros mais simples e subjetivos encontrados na literatura ([PAN84], [MCC85], [SCH84], [PLO84], [YU89], [CON85], [NOG86], [SEI84], [SIB85]), que eram mais adequados para a pequena e média empresa brasileira. $O$ trabalho de Vidal consistiu em estudar e verificar, através de um estudo exploratório com ênfase no processo de seleção de pacotes de software administrativo, algumas das principais características do processo de informatização de pequenas e médias empresas no Brasil. Com esse trabalho ele contribuiu para o processo de informatização de empresas, que encontra-se subdividido no seu trabalho em quatro etapas: 1) a definição das necessidades de informação da empresa; 2) a escolha dos softwares adequados; 3) a escolha dos hardwares adequados; e 4) a implantação, operação e manutenção do sistema adquirido. Vidal também pesquisou elementos para facilitar a tomada de decisões quanto à escolha de pacotes de software. Os elementos de qualidade investigados por Vidal foram: desempenho, documentação, atendimento as necessidades, facilidade de uso, facilidade de aprendizado, flexibilidade, custo, reputação do fornecedor, suporte do fornecedor, integração e compatibilidade. A seguir é apresentada resumidamente a pesquisa de Vidal seguindo o método GQM. 


\section{Passo1: Objetivos da Pesquisa de Vidal}

Objeto: Principais aspectos do processo de informatização dando ênfase para os pacotes de software para a área administrativa/financeira.

Proposito: Estudar e verificar, com ênfase no processo de seleção de pacotes de software administrativos para microcomputadores, como ocorreu o processo de informatização das empresas, quais as principais razōes que levaram à sua informatização, como a escolha dos pacotes de software foi realizada, quais foram os critérios de qualidade mais relevantes utilizados no processo de seleção dos pacotes de software e quais os principais problemas enfrentados para informatizar as empresas.

Contexto: Pequenas e médias empresas brasileiras no ano de 1989 que possuíam microcomputadores.

Foco de Qualidade: São os dados sobre o processo de informatização e os fatores ou critérios de qualidade considerados na escolha de pacotes de softwares selecionados.

Perspectiva: Daqueles que têm conhecimento de pacotes de software implantados em alguma empresa ou de quem toma decisões quanto à escolha de pacotes de software ou de quem utiliza os pacotes de software.

\section{Passo 2: Lista de Questões de Interesse da Pesquisa de Vidal}

A lista de questões de interesse da pesquisa realizada por Vidal é apresentada a seguir no Quadro 2.10.

\section{Quadro 2.10 Lista de Questōes de Interesse da Pesquisa de Vidal}

\begin{tabular}{|c|}
\hline Questões sobre o entrevistador \\
\hline (nome, atividade profissional, endereco, telefone) \\
\hline Questōes sobre o entrevistado \\
\hline $\begin{array}{l}\text { (nome do entrevistado, cargo ou função na empresa, razão social na empresa, ramo de atividade, } \\
\text { endereço, faturamento mensal, número de empregados) }\end{array}$ \\
\hline Questōes sobre os pacotes de software administrativos \\
\hline $\begin{array}{l}\text { (nome do software, area de aplicação, nome do fornecedor, data de aquisição, meses em operação, } \\
\text { tipo de microcomputador, principal setor usuário) }\end{array}$ \\
\hline
\end{tabular}


(continuação)

Quadro 2.10 Lista de Questões de Interesse da Pesquisa de Vidal

\section{Questões sobre o processo de informatização da empresa}

(Quais pessoas tiveram o maior empenho para informatizar a empresa ?, Quais pessoas tiveram a maior influência na escolha dos pacotes de software administrativo adquiridos ?, Quanto que a empresa beneficiou-se ou prejudicou-se após a instalação dos pacotes de software administrativos adquiridos ?, Quais as razões que levaram a empresa a informatizar suas rotinas administrativas ?, Quais os conselhos que você daria hoje para quem fosse informatizar uma empresa com a utilização de pacotes de software administrativo ?)

Questões sobre os critérios utilizados na avaliação dos pacotes de software selecionados

\begin{tabular}{|c|c|}
\hline $\begin{array}{l}\text { Fatores considerados na } \\
\text { escolha de pacotes de software } \\
\text { adquiridos }\end{array}$ & $\begin{array}{l}\text { (demonstração e argumento do vendedor, custos e condições de } \\
\text { pagamento compatíveis com a empresa, reputação do fornecedor, } \\
\text { garantia de manutenção do software pelo fornecedor, continuidade } \\
\text { de aprimoramento do software pelo fornecedor, atendimento às } \\
\text { necessidades atuais da empresa, atendimento às necessidades futuras } \\
\text { da empresa, recomendação de outros usuários, aconselhamento de } \\
\text { pessoas especializadas, facilidade de aprendizado e operação, } \\
\text { compatibilidade com o equipamento que a empresa já possuía) }\end{array}$ \\
\hline $\begin{array}{l}\text { Fatores considerados na } \\
\text { avaliação da qualidade dos } \\
\text { pacotes de software adquiridos }\end{array}$ & $\begin{array}{l}\text { (desempenho, documentação, fornecimento de todas informações } \\
\text { necessárias a empresa, facilidade de utilização, capacidade de } \\
\text { adaptação, integração com outros softwares) }\end{array}$ \\
\hline
\end{tabular}

\section{Passo 3: Métricas Usadas por Vidal}

Vidal utilizou-se de dois tipos de métricas: escolha de uma alternativa e a hierarquização de frases que serão ilustradas nos exemplos a seguir. Um exemplo da escolha de uma alternativa entre várias está ilustrada no Quadro 2.11.

Quadro 2.11 Exemplo da Métrica Usada por Vidal: Escolha de Uma Alternativa entre Várias III - Dados sobre a Informatização da Empresa:

\section{Assinale apenas uma das alternativas}

O maior empenho para informatizar a empresa veio de:
a) Funcionários da empresa
b) Os donos ou diretores da empresa
c) Um técnico ou consultor externo
d) Um conhecido
e) Um vendedor
f) Outros, especifique 
A hierarquização de alternativas é estruturada de acordo com a pontuação de notas para as frases, utilizando-se de escalas. Foram adotadas duas escalas na classificação das frases: escala de importância e escala de dificuldade. Ambas possuem um grau máximo, um grau mínimo, um ponto médio e um indiferente, representando o entrevistado sem opinião ou neutro. A escala de importância varia de um até cinco (1 - Sem importância, 2 - Indiferente, 3 - Pouco importante, 4 - Importante, 5 Muito importante) e a escala de dificuldade varia também de um até cinco (1 - Nenhuma dificuldade, 2 - Pouca dificuldade, 3 - Alguma dificuldade, 4 - Grande dificuldade, 5 - Total dificuldade). Um exemplo da hierarquização utilizada por Vidal é ilustrado no Quadro 2.12 abaixo.

\section{Quadro 2.12 Exemplo da Métrica Usada por Vidal: Classificação de Frases com Escala Variando de Um até Cinco}

\section{Dê uma nota (de 1 a 5) para cada uma das alternativas de acordo com escalas}

4 Razôes que levaram a empresa a informatizar suas rotinas administrativas

1 -Sem importância 2 - Indiferente 3 -Pouco importante 4 -Importante 5 -Muito importante Ređução de custos;

Agilização na obtenção de relatórios e informaçoes;

Obtenção de maior quantidade de informaçoes;

Obtenção de maior exatidão nas informaçōes;

Modernização da empresa para melhorar sua administração;

Outros aspectos, especifique

\section{Passo 4: Como Foi Projetado e Testado o Questionário de Coleta de Dados Desenvolvido por Vidal}

Devido ao fato que o questionário foi respondido pelo entrevistado, sem um controle direto por parte do pesquisador, vários aspectos delinearam a forma final do questionário. Alguns desses principais aspectos considerados foram: 1) os questionários deveriam ser curtos, pois haveria restrição de espaço no livro, onde estariam inclusos; 2) os questionários deveriam ser preparados para permitir e facilitar 0 auto preenchimento pelo entrevistado ou pelo entrevistador; 3) admitiu-se que tanto 0 entrevistador (profissional de microinformática) como o entrevistado (usuário de pacotes de software) possuíssem um conhecimento mínimo do assunto da pesquisa, dispensando a necessidade de explicações muito detalhadas; 4) os questionários deveriam ser formados por perguntas fechadas, 
basicamente de três tipos (escolha de uma alternativa entre várias; hierarquização de alternativas; notas para frases, de acordo com escalas); 5) cada pergunta deveria ser curta e tratar de um único assunto, dentro do seu contexto; 6) as alternativas a serem escolhidas deveriam ser breves e mutuamente exclusivas; 7) para evitar ambiguidade de interpretações, as perguntas e afirmações deveriam ser bem precisas.

Após a aplicação do teste piloto a sexta versão do questionário foi usada para a coleta de dados.

\section{Passo 5: Como Foi Realizada a Coleta e a Validação de Dados da Pesquisa de Vidal}

A coleta de dados ocorreu através da inclusão do questionário em um livro técnico - Clipper Versão Summer 87 [VID89], na seção “Serviço ao Leitor", publicado em fevereiro de 1989. A đuração da pesquisa foi de 11 meses, compreendendo o período de fevereiro a dezembro de 1989. Muitos dos questionários recebidos foram respondidos de forma incompleta ou incorreta, isto necessitou de uma triagem antes da realização da análise. Assim dos 691 questionários recebidos, apenas 439 puderam ser efetivamente aproveitados para a análise de dados.

\section{Passo 6: Resultados da Análise de Dados da Pesquisa Realizada por Vidal}

Os elementos de avaliação estudados e propostos por Vidal [VID90] a serem utilizados em futuras pesquisas de avaliação de pacotes de software são: atendimento às necessidades da empresa, funcionalidade e modularidade, desempenho, segurança, capacidade de auditoria, capacidade de expansão, flexibilidade, capacidade de adaptação, suporte e assistência técnica, método, facilidade de uso, facilidade de aprendizado, documentação, testabilidade, nível de consumo de recursos computacionais, portabilidade, integração e compatibilidade, qualidade do fornecedor, custos e condiçōes de pagamento.

Em relação ao perfil do processo de informatização da empresa em 1989, teve início aproximadamente em 1987 e os equipamentos utilizados foram microcomputadores compatíveis com o IBM-PC da IBM, que se tornaram na época um padrão. As rotinas que estavam sendo mais automatizadas na pequena e média empresa eram, por ordem, a contabilidade, a folha de pagamento e o controle de estoques e os proprietários ou dirigentes das pequenas e médias empresas foram os maiores 
responsáveis pelo início do processo de informatização, sendo os que mais se empenharam em concretizá-lo.

Das principais razões que levaram na época à informatização das pequenas e médias empresas estava, em primeiro lugar, uma busca pela qualidade das informações; em segundo lugar, a redução dos custos; e em terceiro lugar, a procura pela modernização da empresa.

A pessoa de maior influência na forma de como foi realizada a escolha de pacotes de software está representada entre os dirigentes da empresa, os funcionários que irão diretamente utilizá-los e um técnico ou consultor externo; e foram avaliados basicamente dois fatores: em primeiro lugar a adequação do software à empresa (incluindo atendimento às necessidades e qualidade); e, em segundo, a forma de sua comercialização (incluindo custo).

Vidal verificou que os critérios mais relevantes utilizados no processo de seleção dos pacotes de software obedecem a seguinte ordem: em primeiro lugar está o desempenho, fornecimento de informaçōes, documentação e facilidade de utilização; em seguida está a capacidade de adaptação do software às necessidades da empresa; e, em terceiro lugar está a compatibilidade ou capacidade de integração com outros softwares.

Os principais problemas enfrentados para informatizar a empresa, em ordem decrescente de importância, foram os seguintes: dificuldade de utilização do sistema (hardware e software), o que leva a concluir que na época ainda havia muito o que se aprimorar em termos de facilidade de utilização dos softwares; dificuldade de escolha do sistema, o que valida a principal preocupação do trabalho desenvolvido por Vidal; dificuldade de capacitação dos usuários para utilização do sistema; e dificuldade econômica em arcar com os custos gerados pela informatização.

As recomendaçōes dos usuários, após a experiência adquirida com a informatização da empresa, foram: em primeiro lugar é necessário que se tenha certeza de que o software selecionado é adequado para a empresa e que as pessoas que irão utilizá-los sejam bem treinadas; em segundo lugar deve-se inicialmente organizar a empresa para depois informatizá-la e; em terceiro lugar, os usuários acham que é útil a contrataçāo de um profissional especializado para prestar assessoria. 


\subsubsection{Método do CTI}

A Fundação Centro Tecnológico para Informática (CTI) baseia-se nas Normas NBR 13596 (Versão em português da Norma ISO/IEC 9126), que foi descrita anteriormente na Seção 2.1.1, e na ISO/IEC 12119 [ISO/IEC-12119] para desenvolver o seu método de avaliação de produto de software [CT196]. A avaliação é realizada anualmente pelo CTI no contexto prêmio ASSESPRO. O trabalho descrito aqui é referente ao ano de 1996, mas cabe mencionar que o método do CTI passou por evoluções, além de modificações na categoria do prêmio, nas regras e no cadastro do participante. Atualmente o CTI realiza a avaliaçāo de produto de software através do método MEDE-PROS e de acordo com os criterios de avaliação estabelecidos para o prêmio ASSESPRO do ano de 1999. Esse método surgiu com o aprimoramento de estudos conduzidos durante anos e tem como objetivo avaliar o produto de software sob o ponto de vista de um usuário final. O MEDE-PROS tem como referência as normas NBR 13596 e ISO/AEC 12119 [OL97] e é composto por uma Lista de Verificaçāo (e composta por questões que são dependentes do objetivo da avaliação e que são agrupadas de acordo com os componentes de produto e software: embalagem, pacote, documentaçāo, interface e software), um Manual do Avaliador (contempla a Lista de Verificação, orientando o avaliador sobre o processo de avaliação) e o Modelo de Relatório de Avaliação (e um modelo para que o avaliador possa elaborar o relatório de avaliação).

\section{Passo 1: Objetivos da Pesquisa Realizada pelo CTI}

Objeto: São pacotes de software.

Propósito: Avaliaçāo de pacotes de software de acordo com características da ISO/IEC 9126 e da ISO/IEC 12119 para premiaçāo do melhor software do ano.

Contexto: Laboratório do CTI para as análises dos produtos das empresas que estão participando do prêmio ASSESPRO. 
Foco de Qualidade: As características e subcaracterísticas de qualidade de produto de software da ISO/IEC 9126 e os aspectos do pacote de software ISO/IEC 14598 [ISO/IEC-14598] e da ISO/IEC 12119.

Perspectiva: Das pessoas da área de engenharia de software treinadas para avaliar os pacotes de software.

\section{Passo 2: Lista de Questões de Interesse do CTI}

Foi utilizada a Norma da ISO/IEC 9126 e também da ISO/IEC 14598. No Quadro 2.13 é apresentada a lista de questōes de interesse baseada no questionário do CTI do ano de 1996.

\section{Quadro 2.13 Lista de Questōes de Interesse do CTI}

\begin{tabular}{|c|c|}
\hline \multicolumn{2}{|c|}{ Questões sobre o avaliador } \\
\hline \multicolumn{2}{|c|}{ nome do avaliador, codigo do avaliador } \\
\hline \multicolumn{2}{|c|}{ Questões sobre o produto } \\
\hline \multicolumn{2}{|c|}{$\begin{array}{l}\text { Categoria, codigo do produto, nome, descrição resumida, ambiente, embalagem, material apresentado } \\
\text { (disquetes, CD-ROM, manuais (impresso ou on-line)) }\end{array}$} \\
\hline \multicolumn{2}{|c|}{ Questões sobre as condições de operação e instalação } \\
\hline \multicolumn{2}{|c|}{$\begin{array}{l}\text { Espaço em disco rígido, memoria normal/estendida/expandida, software especial, hardware especial, } \\
\text { monitor, impressora }\end{array}$} \\
\hline \multicolumn{2}{|c|}{ Questões sobre os tempos gastos na avaliação } \\
\hline \multicolumn{2}{|c|}{$\begin{array}{l}\text { Verificação inicial, instalação e desinstalação, familiarização/leitura de manuais, avaliação da } \\
\text { documentação, avaliação da interface, avaliação do software, avaliação do mercado, preenchimento } \\
\text { da súmula, tempo gasto com problemas, tempo total }\end{array}$} \\
\hline \multicolumn{2}{|c|}{ Questôes sobre as características de qualidade da ISO/tEC 9126} \\
\hline Embalagem & Aspectos relacionados à embalagem \\
\hline Pacote & Descrição do produto, descrição dos componentes do produto \\
\hline Documentaçāo & $\begin{array}{l}\text { Funcionalidade (adequação, acurácia, inteligibilidade, apreensibilidade, } \\
\text { operacionalidade) }\end{array}$ \\
\hline Interface & $\begin{array}{l}\text { Funcionalidade (adequação, acurácia, conformidade), Usabilidade } \\
\text { (Inteligibilidade, apreensibilidade, operacionalidade) }\end{array}$ \\
\hline Software & $\begin{array}{l}\text { Funcionalidade (adequação, acurácia, interoperabilidade, conformidade, } \\
\text { segurança de acesso), Eficiencia (comportamento em relação ao tempo, } \\
\text { comportamento em relação aos recursos), Portabilidade (adaptabilidade, } \\
\text { instabilidade, substituibilidade) }\end{array}$ \\
\hline Mercado consumidor & O produto no contexto do mercado consumidor \\
\hline
\end{tabular}




\section{Passo 3: Métricas Usadas no CTI}

Para cada uma das questões o avaliador deve estabelecer quanto o produto se aproxima das proposições negativa (à esquerda) ou positiva (à direita). As gradações podem variar de 1 até 5 (5 - o produto atende plenamente, 4 - o produto atende satisfatoriamente, 3 - o produto atende parcialmente, 2 - 0 produto não atende em alguns aspectos fundamentais, 1 - o produto não atende). Pode ocorrer que a questão nāo se aplica ao produto, então deverá ser assinalado "NA", ou quando o avaliador não tem condiçōes de avaliar a questão, ou seja, a avaliação fica prejudicada “AP”. O avaliador tambem possui espaço em uma folha anexa para fazer suas observaçōes referente ao produto. $O$ exemplo da característica Funcionalidade, subcaracterística Adequação - definição e completeza usada no ano de 1996 é ilustrada no Quadro 2.14.

\section{Quadro 2.14 Exemplo da Métrica Usada no CTI em 1996}

\section{Software - Adequação - definição e completeza}

Parte das funções não estão bem definidas. O conjunto de funções cobre apenas parte das necessidades a que se propõe o software

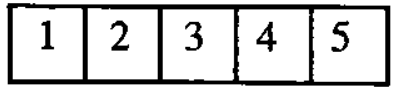

NA AP
As funções estão bem definidas e cobrem de forma completa as necessidades a que se propõe o software

\section{Passo 4: Como Foi Projetado e Testado o Questionário de Coleta de Dados Desenvolvido no CTI}

O questionário foi projetado utilizando como referência as normas NBR 13596, que define as características de qualidade de software que devem estar presentes em todos os produtos: Funcionalidade, Confiabilidade, Portabilidade, Usabilidade, Eficiência e Manutenibilidade, e ISO/IEC 12119 que trata dos requisitos de qualidade e testes de pacotes de software, na forma como são oferecidos e liberados para uso. Todo o ano o questionário passa por estudos e adaptações levando em consideração a análise dos dados obtida do prêmio ASSESPRO realizada por pesquisadores e colaboradores do CTI. 


\section{Passo 5: Como Foi Realizada a Coleta e a Validação dos Dados do CTI}

Foi disponível um produto por sala e a avaliação foi dividida em duas fases: fase eliminatória, onde foram examinados se o produto de software candidato ao prêmio cumpre os aspectos legais do concurso e de instalação do produto; e fase de pontuação, onde as características de qualidade foram avaliadas por simular uma situação de utilização normal pelo usuário e visando os seguintes aspectos: embalagem, pacote, documentação, interface, software e mercado consumidor.

\section{Passo 6: Resultados da Análise de Dados do CTI}

Como resultado da análise da coleta de dados em [TSU96], verificou-se que das seis características da ISO 9126, duas são sempre mais importantes: Funcionalidade e a Confiabilidade. A importância relativa das outras 4 características é muito dependente das condições das quais o produto software está sendo usado e como está sendo desenvolvido. As seguintes observações foram feitas: Funcionalidade (A característica mais importante é também uma das quais podem ser melhor avaliadas do ponto de vista do usuário), Confiabilidade (Avaliação não satisfatória com o pequeno tempo para exercitar os produtos; é possível somente detectar defeitos muito evidentes nesta característica); Manutenibilidade (Como uma característica de qualidade interna ela não pode ser aplicada sem estar disponível o código fonte; para manter uma correspondência com a ISO 9126 ela foi avaliada com respeito a qualidade e disponibilidade dos serviços técnicos e de manutenção); Usabilidade (Sendo diretamente relacionada com o usuário ela pôde ser muito bem avaliada); Eficiência (Avaliação é limitada por simular situações onde o volume de dados e diversidade de operaçōes e dados em situaçōes reais são mal reproduzidas); Portabilidade (Para os tipos de produtos submetidos para a avaliação, muitos deles para ambiente PC-DOS, pôde ser avaliada facilmente).

\subsubsection{Modelo de Belchior}

O trabalho realizado por Belchior identificou os atributos de qualidade de maior relevância ao se considerar a qualidade de software para a área financeira. Ele realizou uma pesquisa empírica nas instituições financeiras instaladas no Brasil utilizando de um modelo de avaliação de qualidade de 
software [ROC87]. A princípio foi feito um estudo dos atributos de qualidade, na literatura, que melhor se adequassem às exigências da área financeira. Ele contribuiu para auxíliar os desenvolvedores e usuários a produzir software financeiro de qualidade e também para ajudar na análise da qualidade de software já desenvolvidos. A seguir é apresentada resumidamente a pesquisa realizada por Belchior seguindo os seis passos do método GQM.

\section{Passo 1: Objetivos da Pesquisa de Belchior}

Objeto: : São softwares para a área financeira.

Propósito: Estudo e análisc das principais características de qualidade.

Contexto: Instituiçōes financeiras instaladas no Brasil.

Foco de Qualidade: Criterios de qualidade de produto de software do modelo de Rocha [ROC87].

Perspectiva: Analistas de sistemas que desenvolveram e/ou dão manutenção e usuários.

\section{Passo 2: Lista de Questões de Interesse da Pesquisa de Belchior}

O seu trabalho foi baseado no modelo desenvolvido por Rocha [ROC87]. No Quadro 2.15 e apresentada a lista de questões de interesse utilizada por Belchior que foram respondidas de acordo com as perspectivas dos usuários que operavam os softwares pesquisados.

\section{Quadro 2.15 Lista de Questões de Interesse da Pesquisa de Belchior}

\begin{tabular}{|c|c|}
\hline \multicolumn{2}{|r|}{ Questōes sobre os Dados Cadastrais } \\
\hline Empresa & Nome da empresa, Endereço \\
\hline Software & $\begin{array}{l}\text { Nome do sistema, Objetivos do sistema, Porte do sistema (pequeno, médio, grande), Instalação } \\
\text { (microcomputador, minicomputador, mainframe), Observaçōes }\end{array}$ \\
\hline \multicolumn{2}{|r|}{ Questões sobre a Confiabilidade Conceitual } \\
\hline \multirow[t]{2}{*}{ Precisāo } & $\begin{array}{l}\text { Os resultados da aplicação estão consistentes com os métodos numéricos } \\
\text { empregados }\end{array}$ \\
\hline & \begin{tabular}{|l|l|} 
Correção & Os resultados obtìdos do programa correspondem ao esperado pelo usuário \\
\end{tabular} \\
\hline \multirow{2}{*}{ Completude } & Completude do programa com relação às funções requeridas pelo usuário \\
\hline & Completude do progr ama com relação as normas de elaboração de códigos fonte da organização \\
\hline
\end{tabular}




\section{Quadro 2.15 Lista de Questões de Interesse da Pesquisa de Belchior}

(continuação)

\begin{tabular}{|c|c|c|}
\hline \multicolumn{3}{|c|}{ Questões sobre a Confiabilidade Conceitual } \\
\hline Necessidade & \begin{tabular}{|l|} 
Necessidade funções \\
implementadas
\end{tabular} & $\begin{array}{l}\text { As funções imprescindíveis ao alcance dos objetivos do projeto estão } \\
\text { implementadas }\end{array}$ \\
\hline \multirow{7}{*}{ Robustez } & \multicolumn{2}{|c|}{ Tolerância a entrada de dados incorretos } \\
\hline & Ratificabilidade & $\begin{array}{l}\text { É permitido a realimentação no programa, pelo operador dos dados de } \\
\text { entrada, para que possam ser validados posteriormente }\end{array}$ \\
\hline & $\begin{array}{l}\text { Detectabilidade } \\
\text { falhas }\end{array}$ & $\begin{array}{l}\text { O programa é capaz de detectar desvios de comportamento esperado } \\
\text { para o software, hardware e operador }\end{array}$ \\
\hline & Recuperabilidade & $\begin{array}{l}\text { O programa possui mecanismos próprios de correção de erros, ou seja, Є } \\
\text { capaz de reconstruir, na forma e no conteúdo desejados, suas } \\
\text { informaçóes }\end{array}$ \\
\hline & Redundância & Existem cópias dos módulos considerados mais críticos \\
\hline & Reparabilidade & Existem mecanismos de reparação do software em tempo hábil \\
\hline & \begin{tabular}{|l|} 
Confinamento de \\
Falhas \\
\end{tabular} & $\begin{array}{l}\text { Os erros, que venham ocorrer em uma determinada parte do programa, } \\
\text { não migram para outras regiôes do mesmo programa }\end{array}$ \\
\hline \multirow{3}{*}{ Segurança } & \begin{tabular}{|l|}
$\begin{array}{l}\text { Detectabilidade } \\
\text { de violação }\end{array}$ \\
\end{tabular} & $\begin{array}{l}\text { O programa possui mecanismos, que evitem danos causados por acessos } \\
\text { indevidos }\end{array}$ \\
\hline & Privacidade & $\begin{array}{l}\text { Há mecanismos de proteção e controle das operações, realizadas por um } \\
\text { determinado indivíduo }\end{array}$ \\
\hline & Sensibilidade & Existem indicações da importância dos dados processados \\
\hline \multirow{3}{*}{ Segurança } & Vulnerabilidade & $\begin{array}{l}\text { Existem mecanismos, que tornem o programa seguro a determinados } \\
\text { tipos de ataque }\end{array}$ \\
\hline & Imputabilidade & $\begin{array}{l}\text { Existem mecanismos, que responsabilizem uma entidade ou um } \\
\text { indivíduo, por suas açốes no manuseio do software }\end{array}$ \\
\hline & Confidenciabilidade & $\begin{array}{l}\text { Há meçanismos, que garantem a proteção das informações contra } \\
\text { acessos não autorizados }\end{array}$ \\
\hline \multicolumn{3}{|r|}{ Questões sobre a Utilizabilidade } \\
\hline \multirow[t]{2}{*}{ Alterabilidade } & $\begin{array}{l}\text { Alterabilidade } \\
\text { corretiva }\end{array}$ & $\begin{array}{l}\text { O programa encontra-se implementado a facilitar possíveis correções de } \\
\text { erros ou alterações funcionais }\end{array}$ \\
\hline & $\begin{array}{l}\text { Alterabilidade } \\
\text { evolutiva }\end{array}$ & $\begin{array}{l}\text { O programa encontra-se implementado a facilitar possíveis melhorias e } \\
\text { evoluções }\end{array}$ \\
\hline Oportunidade & Tempestividade & Os resultados do programa atendem ao usuário, no tempo oportuno \\
\hline \multirow{3}{*}{$\begin{array}{l}\text { Amenidade de } \\
\text { uso }\end{array}$} & Facilidade de uso & $\begin{array}{l}\text { O programa possui requisitos, que facilitem sua manipulação pelo } \\
\text { usuário }\end{array}$ \\
\hline & Apresentação & $\begin{array}{l}\text { O programa tem interfaces gráficas ou outras características, que } \\
\text { facilitem a apresentação de informaçōes }\end{array}$ \\
\hline & Seleção de auxílios & $\begin{array}{l}\text { O programa possui meios de apresentar seus procedimentos e suas } \\
\text { características, no instante que o usuário desejar }\end{array}$ \\
\hline \multirow[t]{2}{*}{$\begin{array}{l}\text { Independência } \\
\text { do ambiente }\end{array}$} & $\begin{array}{l}\text { Independência } \\
\text { hardware }\end{array}$ & O programa pode ser executado em diferentes ambientes de hardware \\
\hline & $\begin{array}{l}\text { Independência } \\
\text { software }\end{array}$ & O programa pode ser executado em diferentes ambientes de software \\
\hline $\begin{array}{l}\text { Configurabilid } \\
\text { ade }\end{array}$ & $\begin{array}{l}\text { Conformação com o } \\
\text { ambiente }\end{array}$ & $\begin{array}{l}\text { O programa faz uso de facilidades do ambiente onde executa, não } \\
\text { comprometendo sua independência }\end{array}$ \\
\hline
\end{tabular}


Quadro 2.15 Lista de Questões de Interesse da Pesquisa de Belchior

\begin{tabular}{|c|c|c|}
\hline \multicolumn{3}{|c|}{ Questões sobre a Utilizabilidade } \\
\hline Generabilidade & $\begin{array}{l}\text { Independência da } \\
\text { quantidade de dados }\end{array}$ & O programa não possui limitações para qualquer quantidade de dados \\
\hline Adaptabilidade & $\begin{array}{l}\text { Composiçāo } \\
\text { tecnológica }\end{array}$ & $\begin{array}{l}\text { O código fonte pode ser facilmente reusado, sem alterações ou } \\
\text { modificaçóes significativas }\end{array}$ \\
\hline $\begin{array}{l}\text { Eficiência } \\
\text { execução }\end{array}$ & \multicolumn{2}{|c|}{$\begin{array}{l}\text { Refere-se à característica de um programa executar suas funções dentro do menor tempo } \\
\text { possível }\end{array}$} \\
\hline Lucratividade & Taxa de retorno & $\begin{array}{l}\text { A taxa de retorno da utilização do programa é superior ao } \\
\text { investimento fcito em sua confecção ou em sua aquisição }\end{array}$ \\
\hline \multirow[b]{2}{*}{ Verificabilidade } & Documentação & O programa possui documentação disponfvel e de boa qualidade \\
\hline & \begin{tabular}{|l|l|} 
Organização \\
documentação
\end{tabular} & $\begin{array}{l}\text { Existe uma forma sistemática de organização dos códigos fontes e de } \\
\text { suds documentações, agilizando o acesso aos mosmos }\end{array}$ \\
\hline Validabilidade & \multicolumn{2}{|c|}{$\begin{array}{l}\text { É a característica de um programa poder ser facilmente, avaliado dentro de um processo } \\
\text { finito, e economicamente viável }\end{array}$} \\
\hline
\end{tabular}

\section{Passo 3: Métricas Usadas por Belchior}

Os requisitos de qualidade foram avaliados de acordo com o grau de importância que possuíam para o entrevistado retratando como o sistema deveria estar, e nāo o estado em que se apresentava. Foi atribuído para o grau de importância uma escala de valores inteiros variando de zero até cinco de acordo com o Quadro 2.16 apresentado abaixo.

\section{Quadro 2.16 Exemplo da Métrica Usada por Belchior}

\begin{tabular}{|l|c|c|c|}
\hline Subfatores & Critérios & Grau de Importância & Peso \\
\hline Precisão & Acurácia & Extremamente alto, Alto, Médio Baixo, Muito Baixo, Ausente & \\
\hline
\end{tabular}

No Quadro 2.17 e mostrado como poderia ser preenchido o questionário pelo entrevistado, ou seja, com a atribuição de pesos podendo variar de zero até cinco.

Quadro 2.17 Tabela de Peso Usada por Belchior

\begin{tabular}{|r|c|l|}
\hline \multicolumn{1}{|c|}{ Peso } & Sigla & Descricão do grau de importância \\
\hline 5,0 & $\mathrm{E}$ & Extremamente alto \\
\hline 4,0 & $\mathrm{~A}$ & Alto \\
\hline 3,0 & $\mathrm{ME}$ & Médio \\
\hline 2,0 & $\mathrm{~B}$ & Baixo \\
\hline 1,0 & $\mathrm{MB}$ & Muito Baixo \\
\hline 0,0 & $\mathrm{NE}$ & Nenhum ou ausente \\
\hline
\end{tabular}




\section{Passo 4: Como Foi Projetado e Testado o Questionário de Coleta de Dados Desenvolvido por Belchior}

Como foram elaborados dois questionários distintos a serem respondidos pelos analistas de sistemas e pelos usuários então foram realizados testes pilotos com cinco pessoas com o mesmo perfil dos elementos a serem investigados, sendo três analistas de sistemas e dois usuários. A aplicação do questionário ocorreu através de entrevista realizada pessoalmente.

\section{Passo 5: Como Foi Realizada a Coleta e Validação dos Dados da Pesquisa de Belchior}

A pesquisa foi realizada em 12 instituições financeiras, onde a coleta de dados estendeu-se a 46 entrevistados, com um total de 99 sistemas pesquisados, ressalta-se que cada entrevistado podia responder, de acordo com o questionário, até por quatro sistemas diferentes. Devido a extensão dos questionários Belchior optou pela aplicaçāo em forma de entrevista, onde o entrevistado ficava somente com o seu questionário e o entrevistando com o respectivo manual explicativo dos requisitos de qualidade de software financeiro. Cada item dos quadros do questionário era explanado com a ajuda do manual explicativo ou através de explicações verbais, de acordo com o interesse ou solicitações do entrevistado. Assim, todos os problemas que surgiram foram resolvidos no momento que ocorreram.

\section{Passo 6: Resultados da Análise dos Dados da Pesquisa Realizada por Belchior}

A pesquisa de campo realizada por Belchior [BEL92] serviu para que fossem identificados os principais atributos de qualidade de um software financeiro, traçando-se, assim, o perfil de qualidade do mesmo. Mostrou-se que as aplicações financeiras exigem que seus produtos de software possuam um alto teor de qualidade através dos altos pesos dos atributos de qualidade obtidos na pesquisa e que os usuários são mais exigentes que os analistas de sistemas em relação aos requisitos de qualidade dos sistemas financeiros. Dentre os atributos de qualidade pesquisados por Belchior, a precisão recebeu de analistas e de usuários o peso máximo da escala estabelecida. Portanto há um consenso de que um software financeiro que não seja preciso é de uso quase que proibitivo na área de finanças. Notou-se também que a independência do ambiente recebeu o menor peso. Portanto, um software financeiro bem produzido não depende, em geral, do ambiente, para que opere satisfatoriamente. A análise estatística dos resultados foi realizada através do pacote de software estatístico SPSS/PC [SPS84]. 


\subsection{Considerações Finais}

A pesquisa de Vidal baseou-se em McCall [MCC79] e outras caracteristicas de qualidade encontradas na literatura na época. Através da pesquisa de Vidal foi mostrado como se encontrava nas pequenas e médias empresas os pacotes de software adquiridos e como foi realizado o processo de informatização fornecendo elementos de qualidade como guia para a informatização de empresas através da compra de pacotes de software para a área administrativa/financeira.

Belchior em sua pesquisa utilizou questionários distintos para avaliar a qualidade de produto de software, levando em consideração o estudo realizado das características de qualidade, separando os entrevistados em dois grupos, o grupo de usuários dos softwares e o grupo de analistas de sistemas que desenvolveram os sistemas ou prestavam manutenção. Ele utilizou o modelo de Rocha [ROC87]. Belchior avaliou a importância para o usuário e para o analista de sistemas dos atributos de qualidade de software para a área financeira e consolidou os dois pontos de vistas, analisando como o software deveria se apresentar para cada um dos entrevistados e não como o software apresentava-se.

O CTI realiza anualmente a avaliação de pacotes de software através do prêmio ASSESPRO utilizando de um questionário de avaliação que foi baseado nas normas ISO/IEC 9126 e na ISO/IEC 12119. Atualmente o CTI utiliza o método MEDE-PROS.

No Quadro 2.18 relaciona-se o significado dos fatores, elementos e características de qualidade dos modelos de qualidade de produto de software descritos neste capítulo, com isso houve uma tentativa de nivelar e classificar na medida do possível o significado dos termos de qualidade utilizados nas pesquisas realizadas.

Conforme foi visto neste capítulo, as características e os elementos de qualidade de produto de software que foram usados em pesquisas empíricas realizadas no Brasil na área de engenharia de software para a avaliação do produto de software. Essas características e os elementos de qualidade poderão ser combinados e usados para o desenvolvimento do questionário de avaliação de produto de software. $\mathrm{O}$ questionário será desenvolvido e discutido em maiores detalhes no próximo capítulo. 
Quadro 2.18 Relacionamento das Características de Qualidade de Produto de Software

\begin{tabular}{|c|c|c|}
\hline Vidal & Belchior & CTI \\
\hline Desempenho & Acurácia & Acurácia \\
\hline Desempenho & Correção & Acurácia \\
\hline $\begin{array}{l}\text { Atendimento as necessidades } \\
\text { futuras }\end{array}$ & $\begin{array}{l}\text { Completude do programa com relação às } \\
\text { funções requeridas pelo usuário }\end{array}$ & Adequação \\
\hline Facilidade de aprendizado & $\begin{array}{l}\text { Completude do programa com relação as } \\
\text { normas de elaboração de códigos fontes de } \\
\text { organização }\end{array}$ & Adequação \\
\hline \multirow[t]{14}{*}{$\begin{array}{l}\text { Atendimento às necessidades } \\
\text { atuais }\end{array}$} & Necessidade das funções implementadas & Adequação \\
\hline & Tolerância a entrada de dados incorretos & Tolerância a falhas \\
\hline & Ratificabilidade & Operacionalidade \\
\hline & Detectabilidade de falhas & Analisabilidade \\
\hline & Recuperabilidade & Recuperabilidade \\
\hline & Redundância - cópia & Recuperabilidade - backup \\
\hline & Reparabilidade & Recuperabilidade \\
\hline & Confinamento de falhas & Tolerância a Falhas propagação \\
\hline & Detectabilidade de violação & Segurança \\
\hline & Privacidade & Segurança \\
\hline & Sensibilidade & Segurança \\
\hline & Vulnerabilidade & Segurança \\
\hline & Imputabilidade & Segurança \\
\hline & Confidenciabilidade & Segurança \\
\hline $\begin{array}{l}\text { Garantia de manutenção por } \\
\text { parte do fornecedor }\end{array}$ & Alterabilidade corretiva & Modificabilidade \\
\hline Continuidade de aprimoramento & Alterabilidade evolutiva & Modificabilidade \\
\hline Desempenho (rapidez) & Tempestividade & $\begin{array}{l}\text { Comportamento em relação ao } \\
\text { tempo }\end{array}$ \\
\hline Facilidade de uso & Facilidade de uso & Operacionalidade \\
\hline Facilidade de uso & Apresentaçāo & \begin{tabular}{|l|} 
Inteligibilidade \\
\end{tabular} \\
\hline Facilidade de uso & Seleção de auxílios & Inteligibilidade \\
\hline \multirow[t]{2}{*}{$\begin{array}{l}\text { Compatibilidade com } \quad 0 \\
\text { equipamento }\end{array}$} & Independência de hardware & Adaptabilidade \\
\hline & Independência de software & Adaptabilidade \\
\hline \multirow[t]{3}{*}{ Compat. com o equipamento } & Conformação com o ambiente & Portabilidade - conformidade \\
\hline & Independência de quantidade de dados & Operacionalidade \\
\hline & Composição tecnológica & Substituibilidade \\
\hline Desempenho (rapidez) & Eficiência de execução & $\begin{array}{l}\text { Comportamento em relação ao } \\
\text { tempo }\end{array}$ \\
\hline Custo compatível & Taxa de retorno (custo/benefício) & \\
\hline $\begin{array}{l}\text { Documentação } \\
\text { completos) }\end{array}$ (manuais & Documentação & Usabilidade \\
\hline \multirow[t]{2}{*}{ Documentação (adequada) } & Organização da documentação & Usabilidade \\
\hline & Validabilidade & Testabilidade \\
\hline Integração com outros softwares & & Interoperabilidade \\
\hline
\end{tabular}




\section{Capítulo 3}

\section{A PESQUISA SOBRE A AVALIAÇÃO DA QUALIDADE DE PACOTES DE SOFTWARE DA ÁREA DE SISTEMAS DE INFORMAÇÃO EM OPERAÇÃO}

\subsection{Considerações Iniciais}

O objetivo deste trabalho é fornecer mecanismos para a avaliação de qualidade de pacotes de software em operação na área de sistemas de informação em um ambiente empresarial. Como resultado procura-se fornecer um quadro do contexto do parque de pacotes de software em operação, para o apoio da tomada de decisão gerencial. A decisão gerencial pode ser a compra de um novo pacote de software, caso o pacote de software instalado nāo esteja adequado para a empresa; a realização de um novo treinamento deste pacote de software; a atualização ou não da versão do pacote de software; entre outras. Assim, os resultados desta pesquisa interessam às pessoas que estão envolvidas com a área de informática como os analistas de sistemas, os gerentes e as pessoas que utilizam os pacotes de software, pois é dada ênfase para a visão do usuário, ou seja, para o usuário operacional.

\subsection{Planejamento da Avaliação}

O planejamento para o desenvolvimento dos mecanismos da avaliação da qualidade de pacotes de software será realizado com o suporte do método GQM. A pesquisa será desenvolvida seguindo os passos do método. Serão desenvolvidos o Passo 1, Passo 2, Passo 
3 e Passo 4. O Passo 5 e o Passo 6 serão desenvolvidos no Capítulo 4, através de um estudo de caso realizado na empresa Ceterp S/A.

\subsubsection{Passo 1: Objetivos da Pesquisa}

Objeto: Pacotes de software em operação na área de sistemas de informação.

Próposito: Avaliação da adequação ao ambiente empresarial, da qualidade da documentação, dos serviços de manutenção, do treinamento realizado, da documentação de treinamento, dos serviços técnicos prestados, da necessidade de atualização da versão do pacote de software.

Foco de Qualidade: As características de qualidade da ISO/IEC 9126 e os elementos de qualidade de produto de software.

Contexto: Ambiente empresarial dos pacotes de software em operação.

Perspectiva: De quem opera o pacote de software.

\subsubsection{Passo 2: Lista de Questões de Interesse}

As questões de interesse da pesquisa, apresentadas no Quadro 3.1, estão relacionadas com os módulos de avaliação a ser construídos. Para o desenvolvimento das questōes de interesse de cada módulo será utilizada a Norma ISO/IEC 9126 como orientação, que trata de características de qualidade de produto de software.

A avaliação pode ser planejada com diferentes objetivos e perspectivas. Nesse sentido procurou-se caracterizar módulos de avaliação de forma que possa-se adequar o esforço de avaliação com as necessidades de evolução do ambiente empresarial. O resultado obtido é o questionário que apresenta-se estruturado em modulos de avaliação e é representado na Figura 3.1, os módulos estão relacionados com as questões de interesse levantadas neste trabalho: a qualidade do pacote de software e os serviços oferecidos pelo fornecedor deste 
pacote (1 - Adequação do Pacote de Software ao Ambiente Empresarial, 2 - Qualidade da Documentação, 3 - Serviços de Manutenção, 4 - Treinamento Realizado, 5 - Documentação de Treinamento, 6 - Serviços Técnicos Prestados, 7 - Atualização de Versão do Pacote de Software).

Quadro 3.1 Lista de Questōes de Interesse a Serem Respondidas pela Pesquisa

\begin{tabular}{|l|}
\hline \multicolumn{1}{|c|}{ Lista de Questões de Interesse } \\
\hline 1 - O pacote de software está adequado ao ambiente empresarial ? \\
\hline 2 - Qual a qualidade da documentação do pacote de software ? \\
\hline 3 - Como são os serviços de manutenção do pacote de software? \\
\hline 4 - Como foi o treinamento do pacote de software ? \\
\hline 5 - Qual a qualidade da documentação de treinamento do pacote de software ? \\
\hline 6 - Como são os serviços técnicos prestados pelo fornecedor do pacote de software? \\
\hline 7 - Existe necessidade de atualizar a versão do pacote de software ? \\
\hline
\end{tabular}

A divisão em módulos facilita a aplicação e a obtenção de dados para oferecer subsídios para se alcançar a um determinado objetivo empresarial, por exemplo: verificar se o pacote de software está adequado ao ambiente empresarial, como está a qualidade da documentação (manual do usuário), qualidade de treinamento, se o suporte técnico está atendendo satisfatoriamente, se o usuário está satisfeito com os serviços de manutenção, se existe a necessidade de atualização do pacote de software, ou seja, o gerente consegue visualizar a qualidade do pacote de software e a qualidade da implantação deste pacote de software e tomar as decisōes em relação ao pacote de software. 
Figura 3.1 Módulos de Avaliação da Qualidade de Pacotes de Software

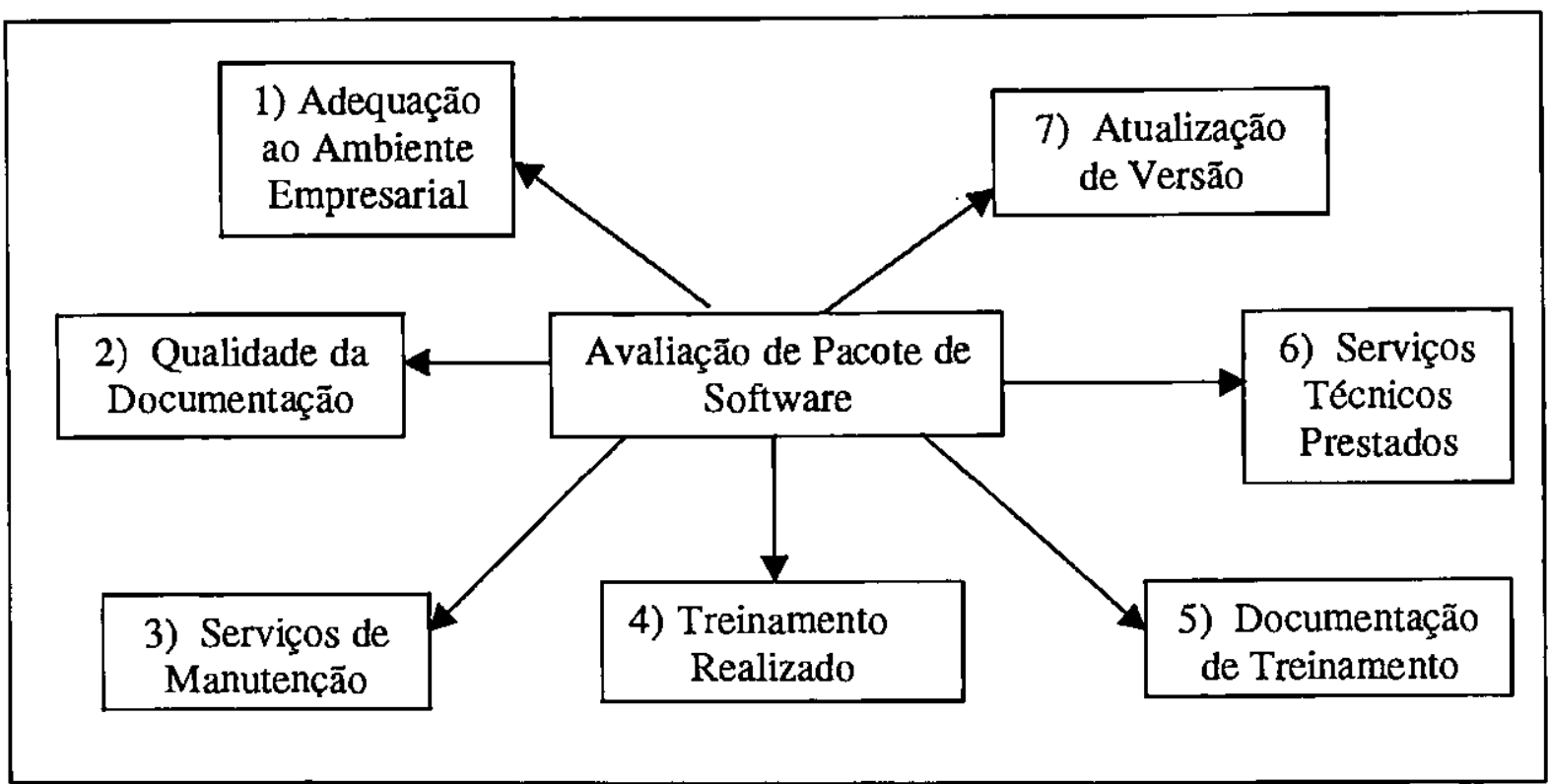

O Quadro 3.2 apresenta as questōes de interesse adicionais, procurando-se caracterizar o entrevistado e o pacote de software que será avaliado.

Quadro 3.2 Questōes de Interesse Adicionais

\begin{tabular}{|l|l|}
\hline \multicolumn{2}{|c|}{ Questões de Interesse Adicionais } \\
\hline Questões sobre o entrevistado & Empresa, Nome, Cargo, Setor, Telefone e Ramal \\
\hline Questōes sobre o pacote de software & $\begin{array}{l}\text { Pacote de Software, Versão, Mes e Ano em que } \\
\text { entrou em operação, Nome da empresa que } \\
\text { desenvolveu, Nome da empresa fornecedora do } \\
\text { software, Telefone suporte técnico }\end{array}$ \\
\hline
\end{tabular}

A seguir cada módulo será desenvolvido dando origem as outras questões de interesse. Foi adotada uma estrutura para o desenvolvimento das questões de cada modulo obedecendo, de maneira geral, a seguinte ordem: codigo do modulo (M1, M2, M3, M4, M5, M6, M7, M8), nome do modulo, característica e/ou subcaracterística da ISO/IEC 9126, número da questão, questão e a palavra chave que serve para a identificação da questão. Exemplo da estrutura da questão: 


\section{M1 - Adequação ao Ambiente Empresarial - Funcionalidade - Adequação}

M1-1 O usuário está satisfeito com software ? (palavra chave: satisfação do usuário).

A questão obedece a seguinte estrutura: código do módulo: M1; nome do módulo: Adequação ao Ambiente Empresarial; característica de qualidade: Funcionalidade; subcaracterística de qualidade: Adequação; número da questão: 1; questão: O usuário está satisfeito com o software ?; palavra chave: satisfação do usuário.

\section{Lista de Questões do Módulo 1: Adequação ao Ambiente Empresarial}

No modulo adequação ao ambiente empresarial são apresentadas questões relacionadas com a adequação do pacote de software para a empresa de acordo com a visão de quem opera o software.

M1 - Adequação ao Ambiente Empresarial - Funcionalidade - Adequação

M1-1 O usuário está satisfeito com o software (palavra chave: satisfação do usuário)

M1-2 As funçōes desejadas por você e pelas outras pessoas estão implementadas no software (palavra chave: completitude)

M1-3 O software está próximo da realidade da empresa (palavra chave: fluxos de informaçōes, processos)

\section{M1 - Adequação ao Ambiente Empresarial - Funcionalidade - Acurácia}

M1-4 Os dados utilizados pelo software estão corretos e atualizados (palavra chave: exatidão dos dados)

\section{M1 - Adequação ao Ambiente Empresarial - Funcionalidade - Interoperabilidade}

M1-5 Você consegue os dados necessários de outros softwares de outras áreas, via software, ou seja, sem a interferência do analista de sistemas (palavra chave: importar dados)

M1-6 Você consegue disponibilizar os dados para outros usuários via software, ou seja, sem a interferência do analista de sistemas (palavra chave: exportar dados) 
M1 - Adequação ao Ambiente Empresarial - Funcionalidade - Segurança

M1-7 Alguém, além de você, conhece sua senha de acesso ao software (palavra chave: acesso ao software)

M1-8 Você deixa outras pessoas utilizarem sua área de trabalho (palavra chave: outras pessoas utilizam sua área de trabalho)

M1 - Adequação ao Ambiente Empresarial - Confiabilidade - Maturidade

M1-9 Você confia no software (palavra chave: confiança)

M1 - Adequação ao Ambiente Empresarial - Usabilidade - Inteligibilidade

M1-10 Você sabe interpretar os resultados e as mensagens fornecidas (palavra chave: interpretação dos dados)

M1-11 Você conhece o software (palavra chave: abrangência do conhecimento)

M1-12 Você conhece outros softwares similares (palavra chave: outros softwares similares)

M1 - Adequação ao Ambiente Empresarial - Usabilidade - Apreensibilidade

M1-13 O software é fácil de utilizar, aprender (palavra chave: facilidade de utilização)

M1 - Adequação ao Ambiente Empresarial - Usabilidade - Operacionalidade

M1-14 Você sabe operar o software (palavra chave: operação do software)

M1- Adequaçāo ao Ambiente Empresarial - Eficiência - Comportamento em relação ao tempo

M1-15 Você está satisfeito com o tempo de processamento das funções do software (palavra chave: tempo de processamento das funçōes)

M1-16 Você está satisfeito com a velocidade do software (palavra chave: velocidade do software) 
M1- Adequação ao Ambiente Empresarial - Eficiência - Comportamento em relação aos recursos

M1-17 Você está satisfeito com o tempo de impressão de seus relatórios (palavra chave: tempo de impressão)

\section{M1- Adequação ao Ambiente Empresarial - Portabilidade - Instabilidade}

M1-18 Você sabe instalar o software, se a instalação puder ser feita pelo usuário (palavra chave: instalação do software)

\section{Lista de Questôes do Módulo 2: Qual a Qualidade da Documentação ?}

Neste modulo são apresentadas questões sobre a qualidade da documentação que é um recurso importante para o usuário conhecer o pacote de software e tirar dúvidas que aparecem com a utilização do pacote de software, geralmente, antes de contactar o suporte técnico.

\section{M2 - Qualidade da Documentação - Funcionalidade - Adequação}

M2-1 As funções do software estão descritas na documentação (palavra chave: completitude)

M2-2 As informações apresentadas na documentação estão de acordo com as funções do software e livre de inconsistências internas com cada termo possuindo um significado ánico em toda documentação (palavra chave: consistência)

M2 - Qualidade da Documentação - Funcionalidade - Acurácia

M2-3 As informações apresentadas na documentação são corretas para a operação e funcionamento do software (palavra chave: exatidão)

M2 - Qualidade da Documentação - Funcionalidade - Interoperabilidade

M2-4 A documentação faz referências a interfaces com outros softwares de outras áreas (palavra chave: interface) 


\section{M2 - Qualidade da Documentação - Usabilidade -Inteligibilidade}

M2-5 A documentação apresenta-se de forma organizada, por exemplos: divisão de capítulos, tópicos, assuntos (palavra chave: organização)

M2-6 A apresentação visual da documentação é agradável (palavra chave: apresentação visual)

M2-7 O texto da documentação é bem redigido e não possui ambiguidade possibilitando o esclarecimento das funções (palavra chave: clareza)

\section{M2 - Qualidade da Documentação - Usabilidade -Apreensibilidade}

M2-8 Os exemplos utilizados na documentação foram suficientes e adequados ao esclarecimento da dúvida do usuário (pala vra chave: exemplos)

M2-9 As ilustrações (gráficos, desenhos, figuras) são suficientes e adequadas ao esclarecimento das informaçōes necessárias ao seu uso (palavra chave: ilustrações)

\section{M2 - Qualidade da Documentação - Usabilidade - Operacionalidade}

M2-10 A documentação possui índices gerais e remissivos completos e bem organizados que permite a facilidade para você encontrar informações (palavra chave: fácil localização)

M2-11 A documentação possui glossário dos termos técnicos utilizados esclarecendo o usuário. Exemplo: dicionário explicando o termo técnico on-line, batch (palavra chave: glossário)

M2-12 Possui referências cruzadas possibilitando que você encontre a informação desejada (palavra chave: referências cruzadas)

M2-13 A documentação possui indicações para consultas adicionais (livros técnicos, bibliografias) disponíveis para você (palavra chave: consultas adicionais de bibliografia)

M2-14 A forma de apresentação do manual do software garante facilidade de manuseio. Exemplo: tamanho, peso (palavra chave: manuseio)

\section{M2 - Qualidade da Documentação - Portabilidade - Adaptabilidade}

M2-15 Apresenta requisitos de software. Exemplo: indicação de quantidade de memória para instalar o software (palavra chave: manual de instalação, versão)

M2-16 Apresenta requisitos de hardware (palavra chave: manual de instalação, configuração mínima de hardware, requisitos de hardware) 
M2 - Qualidade da Documentação - Portabilidade - Instabilidade

M2-17 A documentação faz referências se você pode ou não instalar o software (palavra chave: instalação)

\section{Lista de Questões do Módulo 3: Como São os Serviços de Manutenção?}

Neste módulo são apresentadas questões sobre a manutenção de serviços oferecidos pela empresa fornecedora do pacote de sofiware e como o usuário percebe esses serviços.

\section{M3 - Serviços de Manutenção - Modificabilidade}

M3-1 Existe a atualização da documentação (palavra chave: atualização da documentação)

M3-2 As mudanças legais necessárias ocorridas no software foram realizadas em tempo hábil para você executar suas tarefas no prazo determinado (palavra chave: atualização do software em tempo hábil para a solução do problema)

M3-3 A empresa disponibiliza as novas versōes do software (palavra chave: novas versões)

\section{Lista de Questões do Módulo 4: Como Foi o Treinamento Realizado?}

Neste módulo são apresentadas questōes sobre o treinamento dado pela empresa fornecedora do pacote de software.

\section{M4 - Treinamento Realizado - Funcionalidade - Adequação}

M4-1 As funções do software foram apresentadas no treinamento (palavra chave: completitude)

M4-2 As informaçōes apresentadas no treinamento foram verificadas e estāo de acordo com o software (palavra chave: consistência)

M4-3 O tempo de treinamento foi suficiente para o conteúdo dado (palavra chave: cronograma) 
M4-4 O usuário ficou satisfeito com o treinamento, parte prática e conceitual (palavra chave: satisfação com o treinamento)

\section{M4 - Treinamento Realizado - Funcionalidade - Acurácia}

M4-5 As informaçōes apresentadas (através de: retroprojetor, oral, documentação específica de treinamento, flip chart, vídeo ou qualquer outra para transmissão de conhecimento) no treinamento foram corretas (palavra chave: exatidão das informações)

\section{M4 - Treinamento Realizado - Usabilidade - Inteligibilidade}

M4-6 O treinamento ocorreu de forma organizada (palavra chave: organização da apresentação)

M4-7 A apresentação visual utilizada no treinamento foi agradável. Exemplo: retroprojetor, datashow (palavra chave: apresentação visual)

M4-8 O treinamento ocorreu com clareza e não possuiu ambiguidade possibilitando o esclarecimento das funçōes (palavra chave: clareza, oratoria)

\section{M4 - Treinamento Realizado - Usabilidade - Apreensibilidade}

M4-9 Os exemplos utilizados no treinamento foram suficientes ao entendimento e adequados ao contexto da empresa (palavra chave: exemplos)

M4-10 As ilustrações (gráficos, desenhos, figuras) utilizadas no treinamento foram suficientes e esclareceu as suas dúvidas (palavra chave: ilustrações)

M4-11 As funçōes do software apresentadas no treinamento foram aprendidas e exercitadas (palavra chave: conceitual e prática)

\section{M4 - Treinamento Realizado - Usabilidade - Operacionalidade}

M4-12 O treinamento apresentou indicações para consultas adicionais disponíveis para você buscar mais informações sobre suas dúvidas (palavra chave: consultas adicionais bibliográficas)

\section{M4 - Treinamento Realizado - Confiabilidade - Maturidade}

M4-13 Ocorreu falha do software no período de treinamento (palavra chave: frequência de falhas) 
M4-14 A falha ocorrida afetou o treinamento (palavra chave: gravidade da falha ocorrida)

\section{Lista de Questões do Módulo 5: Qual a Qualidade da Documentação de Treinamento?}

Neste modulo são apresentadas questões sobre a qualidade da documentação de treinamento que e importante para o usuário conhecer o pacote de softwarc.

\section{M5 - Documentação de Treinamento - Usabilidade - Operacionalidade}

M5-1 O material de treinamento possui índices gerais e remissivos completos e bem organizados que permite a facilidade para encontrar informações (palavra chave: índices)

M5-2 O material de treinamento possui glossário dos termos utilizados para o seu esclarecimento (palavra chave: glossario)

M5-3 Possui referências cruzadas possibilitando encontrar a informação desejada (palavra chave: referências cruzadas)

M5-4 O material de treinamento apresentou indicações para consultas adicionais disponíveis para buscar mais informações sobre suas dúvidas (palavra chave: consultas adicionais bibliográficas)

M5-5 A forma de apresentação do (material de treinamento) manual garante facilidade de manuseio (palavra chave: manuseio)

\section{Lista de Questões do Módulo 6: Como São os Serviços Técnicos Prestados?}

Neste modulo são apresentadas questões sobre como o usuário relaciona-se com a empresa fornecedora do pacote de software destacando a prestação de serviços. 


\section{M6 - Serviços Técnicos Prestados - Suporte Técnico}

M6-1 O usuário está satisfeito com o suporte da empresa fornecedora do software (palavra chave: atendimento pelo fornecedor)

M6-2 Em contato com o suporte telefônico o usuário foi bem atendido (palavra chave: contato telefônico)

M6-3 A dúvida ou problema (necessidade) do usuário foi sanado em tempo hábil para o usuário executar suas tarefas (palavra chave: tempo hábil para solução do problema)

\section{Lista de Questões do Módulo 7: Necessidade de Atualizar a Versão}

Neste modulo são apresentadas questōes sobre a necessidade de realizar ou não a atualização de versão do pacote de software.

\section{M7 - A tualização de Versão do Pacote de Software}

M7-1 O momento é adequado para a atualização do software (palavra chave: implantação da nova versão)

M7-2 A demanda pelas novas funções requisitadas por você e outras pessoas é grande (palavra chave: necessidade de novas funções)

M7-3 A atualização do software vai acrescentar melhoria no software (palavra chave: melhoria nas funções existentes)

M7-4 A atualização substitui alguma função existente ou deixa de aparecer alguma função (palavra chave: substituição de funçōes)

M7-5 Ocorreram mudanças nos processos e fluxos de informações do setor que o software não conseguirá atender (palavra chave: mudanças de processos)

M7-6 Os processos existentes estão automatizados (palavra chave: automatização de processos)

M7-7 A nova versão foi implantada em outra empresa (palavra chave: teste da nova versão) 


\subsubsection{Passo 3: Métricas}

Depois de estabelecidas as questões de interesse o próximo passo é estabelecer as métricas. Em geral, as escalas adotadas na classificação das frases devem possuir um grau máximo, um grau mínimo, um ponto médio e um indiferente e também pode ser permitido ao entrevistado fazer comentários sobre as questões. O peso e a escala de classificação adotada para as questões está apresentada na Tabela 3.1. Assim, do Quadro 3.3 até o Quadro 3.9 é apresentada como cada questão foi classificada usando a Tabela 3.1.

Tabela 3.1 Tabela de Peso da Escala de Classificação

\begin{tabular}{|r|c|r|l|l|l|l|l|}
\cline { 2 - 8 } \multicolumn{1}{c|}{} & \multicolumn{7}{c|}{ Escala de Classificação Adotada } \\
\hline Peso & \multicolumn{1}{c|}{ A } & B & \multicolumn{1}{c|}{ C } & \multicolumn{1}{c|}{ D } & \multicolumn{1}{c|}{ E } & \multicolumn{1}{c|}{ F } & \multicolumn{1}{|c|}{ H } \\
\hline 1 & $80 \sim 100 \%$ & 4 & Toda & Muito, Bastante & Excelente & & Muito antes \\
\hline 2 & $60 \sim 79 \%$ & 3 & Quase toda & Suficiente & Ótimo & & Antes do prazo \\
\hline 3 & $40 \sim 59 \%$ & 2 & Pouca & Pouco & Bom & & No prazo \\
\hline 4 & $20 \sim 39 \%$ & 1 & Muito pouca & Muito pouco & Regular & & Fora do prazo \\
\hline 5 & $0 \sim 19 \%$ & Não & $\begin{array}{l}\text { Nenhuma, } \\
\text { Não }\end{array}$ & Nenhum, Não & Péssimo & & Não \\
\hline 6 & & & & & & Sim & \\
\hline 7 & & & & & & Não & \\
\hline 8 & & & & & & $\begin{array}{l}\text { Sem } \\
\text { resposta }\end{array}$ & \\
\hline
\end{tabular}

O Quadro 3.3 apresenta o resumo do Módulo 1 que avalia a adequação ao ambiente empresarial do pacote de software em operação de acordo com a perspectiva do usuário.

Quadro 3.3 Módulo 1: Adequação do Pacote de Software ao Ambiente Empresarial

\begin{tabular}{|l|l|l|c|}
\hline \multicolumn{4}{|c|}{ M1 - Módulo Adequação ao Ambiente Empresarial } \\
\hline Característica & Subcaracterística & Palavra Chave & \multicolumn{2}{c|}{ Escala de Classificacão } \\
\hline \multirow{3}{*}{ Funcionalidade } & \multirow{3}{*}{ Adequação } & M1-1 Satisfação do usuário & D \\
\cline { 3 - 4 } & & M1-2 Completitude & C \\
\cline { 2 - 4 } & M1-3 Fluxos de informações, processos & D \\
\hline
\end{tabular}


(continuaçāo)

Quadro 3.3 Módulo 1: Adequação do Pacote de Software ao Ambiente Empresarial

\begin{tabular}{|c|c|c|c|}
\hline \multicolumn{4}{|c|}{ M1 - Módulo Adequação ao Ambiente Empresarial } \\
\hline Característica & Subcaracterística & Palavra Chave $\quad$ Escala de Classifi & ção \\
\hline \multirow{5}{*}{ Funcionalidade } & Acurácia & M1-4 Exatidão de dados & A \\
\hline & \multirow{2}{*}{ Interoperabilidade } & M1-5 Importar dados & $\mathrm{F}$ \\
\hline & & M1-6 Exportar dados & $\mathrm{F}$ \\
\hline & \multirow[b]{2}{*}{ Segurança } & M1-7 Acesso ao software & $\mathrm{B}$ \\
\hline & & $\begin{array}{l}\text { M1-8 Outras pessoas utilizam sua área de } \\
\text { trabalho }\end{array}$ & B \\
\hline Confiabilidade & Maturidadc & M1-9 Confiança & $\mathrm{A}$ \\
\hline \multirow{5}{*}{ Usabilidade } & \multirow{3}{*}{ Inteligibilidade } & M1-10 Interpretação dos dados & $\mathrm{C}$ \\
\hline & & M1-11 Abrangência de conhecimento & $\mathrm{C}$ \\
\hline & & M1-12 Outros softwares similares & $\mathrm{B}$ \\
\hline & Apreensibilidade & M1-13 Facilidade de utilização & $\mathrm{D}$ \\
\hline & Operacionalidade & M1-14 Operação do software & $\mathrm{C}$ \\
\hline \multirow{3}{*}{ Eficiência } & \multirow{2}{*}{$\begin{array}{l}\text { Comportamento } \\
\text { em relação ao } \\
\text { tempo }\end{array}$} & M1-15 Tempo de processamento das funções & $\mathrm{E}$ \\
\hline & & M1-16 Velocidade do software & $\mathrm{E}$ \\
\hline & $\begin{array}{l}\text { Comportamento } \\
\text { em relação aos } \\
\text { recursos }\end{array}$ & M1-17 Tempo de impressão & $E$ \\
\hline Portabilidade & Instabilidade & M1-18 Instalação do software & $\mathrm{F}$ \\
\hline
\end{tabular}

O Quadro 3.4 apresenta o resumo do Modulo 2 que avalia a qualidade da documentação, ou seja, o manual do usuário.

Quadro 3.4 Módulo 2: Qualidade da Documentação

\begin{tabular}{|c|l|l|c|}
\hline \multicolumn{4}{|c|}{ M2 - Módulo Qualidade da Documentação } \\
\hline Característica & Subcaracterística & Palavra Chave & \multicolumn{2}{c|}{ Escala de Classificacão } \\
\hline \multirow{4}{*}{ Funcionalidade } & Adequação & M2-1 Completitude & C \\
\cline { 2 - 4 } & M2-2 Consistência & C \\
\cline { 2 - 4 } & Acurácia & M2-3 Exatidão & C \\
\cline { 2 - 4 } & Interoperabilidade & M2-4 Interface & $\mathrm{F}$ \\
\hline
\end{tabular}

(continua) 
(continuação)

Quadro 3.4 Módulo 2: Qualidade da Documentação

\begin{tabular}{|c|c|c|c|}
\hline \multicolumn{4}{|c|}{ M2 - Módulo Qualidade da Documentação } \\
\hline Característica & Subcaracterística & Palavra Chave $\quad$ Escala de Classi & ação \\
\hline \multirow{5}{*}{ Usabilidade } & \multirow{3}{*}{ Inteligibilidade } & M2-5 Organização & $\mathrm{C}$ \\
\hline & & M2-6 Apresentação visual & $\mathrm{D}$ \\
\hline & & M2-7 Clareza & $\mathrm{C}$ \\
\hline & \multirow{2}{*}{ Apreensibilidade } & M2-8 Exemplos & $\mathrm{C}$ \\
\hline & & M2-9 Ilustraçōes & $\mathrm{C}$ \\
\hline \multirow{5}{*}{ Usabilidade } & \multirow{5}{*}{ Operacionalidade } & M2-10 Fácil localização & $\mathrm{F}$ \\
\hline & & M2-11 Glossário & $\mathbf{F}$ \\
\hline & & M2-12 Referências cruzadas & $\mathbf{F}$ \\
\hline & & M2-13 Consultas adicionais de bibliografia & $\mathbf{F}$ \\
\hline & & M2-14 Manuseio & $\mathrm{D}$ \\
\hline \multirow{3}{*}{ Portabilidade } & \multirow{2}{*}{ Adaptabilidade } & M2-15 Manual de instalação do software & $\mathrm{F}$ \\
\hline & & M2-16 Requisitos de hardware & $\mathbf{F}$ \\
\hline & Instabilidade & M2-17 Instalação & $\mathbf{F}$ \\
\hline
\end{tabular}

O Quadro 3.5 apresenta um resumo do Modulo 3 que avalia a qualidade dos serviços de manutenção prestados pela empresa fornecedora do pacote de software.

Quadro 3.5 Módulo 3: Serviços de Manutenção

\begin{tabular}{|c|l|c|}
\hline \multicolumn{3}{|c|}{ M3 - Módulo Serviços de Manutenção } \\
\hline Característica & Palavra Chave Escala de Classificação \\
\hline \multirow{4}{*}{ Modificabilidade } & M3-1 Atualização da documentação & F \\
\cline { 2 - 3 } & $\begin{array}{l}\text { M3-2 Atualização do software em tempo hábil para solução do } \\
\text { problema }\end{array}$ & H \\
\cline { 2 - 3 } & M3-3 Novas versões & $\mathrm{F}$ \\
\hline
\end{tabular}

O Quadro 3.6 apresenta o resumo do Modulo 4 que avalia a qualidade do treinamento realizado. 
Quadro 3.6 Módulo 4: Treinamento Realizado

\begin{tabular}{|c|c|c|c|}
\hline \multicolumn{4}{|c|}{ M4 - Módulo Treinamento Realizado } \\
\hline Característica & Subcaracterística & & Escala de Classificação \\
\hline \multirow{5}{*}{ Funcionalidade } & \multirow{4}{*}{ Adequação } & M4-1 Completitude & $\mathrm{C}$ \\
\hline & & M4-2 Consistência & $\mathrm{C}$ \\
\hline & & M4-3 Cronograma & $\mathrm{D}$ \\
\hline & & M4-4 Satisfaçāo com o treinamento & $\mathrm{D}$ \\
\hline & Acurácia & M4-5 Exatidão das informações & $\mathrm{C}$ \\
\hline \multirow{7}{*}{ Usabilidade } & \multirow{3}{*}{ Inteligibilidade } & M4-6 Organização da apresentaçāo & $\mathrm{C}$ \\
\hline & & M4-7 Apresentação visual & $\mathrm{F}$ \\
\hline & & M4-8 Clareza, oratoria & $\overline{\mathrm{C}}$ \\
\hline & \multirow{3}{*}{ Apreensibilidade } & M4-9 Exemplos & $\mathrm{C}$ \\
\hline & & M4-10 Jlustraçōes & $\mathrm{C}$ \\
\hline & & M4- I1 Conceitual e prática & $\mathrm{C}$ \\
\hline & Operacionalidade & M4-12 Consultas adicionais bibliograficas & $\mathrm{F}$ \\
\hline \multirow{2}{*}{ Confiabilidade } & \multirow{2}{*}{ Maturidade } & M4-13 Freqüência de falhas & $\mathrm{D}$ \\
\hline & & M4-14 Gravidade da falha ocorrida & $\mathrm{F}$ \\
\hline
\end{tabular}

O Quadro 3.7 apresenta o resumo do Módulo 5 que avalia a qualidade da documentação do treinamento realizado pelo usuário.

Quadro 3.7 Módulo 5: Documentação de Treinamento

\begin{tabular}{|l|l|l|c|}
\hline \multicolumn{4}{|c|}{ M5 - Módulo Documentação de Treinamento } \\
\hline Característica & Subcaracterística & Palavra Chave Escala de Classificação \\
\hline \multirow{4}{*}{ Usabilidade } & \multirow{4}{*}{ Operacionalidade } & M5-1 Indices & $\mathrm{F}$ \\
\cline { 3 - 4 } & & M5-2 Glossário & $\mathrm{F}$ \\
\cline { 3 - 4 } & & M5-3 Referências cruzadas & $\mathrm{F}$ \\
\cline { 3 - 4 } & & M5-4 Consultas adicionais bibliográficas & $\mathrm{F}$ \\
\cline { 3 - 4 } & & M5-5 Manuseio & $\mathrm{D}$ \\
\hline
\end{tabular}

A seguir o Quadro 3.8 apresenta um resumo do Módulo 6 que avalia a qualidade dos serviços técnicos prestados para o usuário. 
Quadro 3.8 Módulo 6: Serviços Técnicos Prestados

\begin{tabular}{|l|c|}
\hline \multicolumn{2}{|c|}{ M6 - Módulo Serviços Técnicos Prestados } \\
\hline Palavra Chave & Escala de Classificação \\
\hline M6-1 Atendimento pelo fornecedor & $\mathrm{E}$ \\
\hline M6-2 Contato telefônico & $\mathrm{E}$ \\
\hline M6-3 Tempo hábil para solução do problema & $\mathrm{H}$ \\
\hline
\end{tabular}

O Quadro 3.9 apresenta o resumo do Módulo 7 que avalia a necessidade da atualização de versão de pacote de software.

Quadro 3.9 Módulo 7: Atualização de Versão do Pacote de Software

\begin{tabular}{|c|l|l|c|}
\hline \multicolumn{4}{|c|}{ M7 - Módulo Atualização de Versão do Pacote de Software } \\
\hline Características & Subcaracterísticas & Palavra Chave & \multicolumn{2}{c|}{ Escala de Classificação } \\
\hline \multirow{5}{*}{ Manutenibilidade } & \multirow{4}{*}{ Modificabilidade } & M7-1 Implantação da nova versão & F \\
\cline { 2 - 4 } & & M7-2 Necessidade de novas funções & D \\
\cline { 2 - 4 } & & M7-3 Melhoria nas funçōes existentes & D \\
\cline { 2 - 4 } & & M7-4 Substituição de funções & F \\
\cline { 2 - 4 } & & M7-5 Mudanças de processos & D \\
\cline { 2 - 4 } & & M7-6 Automatização de processos & C \\
\cline { 2 - 4 } & Testabilidade & M7-7 Teste da nova versão & F \\
\hline
\end{tabular}

\subsubsection{Passo 4: Projeto e Teste do Questionário de Coleta de Dados}

Foi realizado um teste piloto em dezembro de 1997 onde foram elaboradas várias versões do questionário de coleta de dados e após a realização deste teste foi aplicado o questionário. Salientou-se que estava fazendo uma avaliação do pacote de software cadastrado no questionário, avaliando cada item pesquisado do sistema em questão, isto significava dizer que as respostas retratariam o estado em que o mesmo se apresentava para $o$ usuário, ou seja, como o usuário percebia o pacote de software pesquisado. O questionário de coleta de dados projetado e testado encontra-se no Anexo 1. 


\subsubsection{Passo 5: Coleta e Validação de Dados e Passo 6: Análise dos Dados}

Mesmo com um número limitado de 2 pessoas foi realizado o Passo 5 e o Passo 6 através do preenchimento do questionário desenvolvido na etapa anterior. Junto a coleta realizou-se a validação dos dados que consistiu em verificar os questionários quanto à não ocorrência de erros, consistência e completitude, assim todos os problemas detectados foram solucionados no momento quc ocorreram. Logo após realizou-se a interpretaçāo dos coletados e analisadas.

\subsection{Considerações Finais}

Neste caṕ́tulo com a aplicação do método GQM foi obtido um questionário de avaliação que levou em consideração as características de qualidade de produto de software, esse questionário está composto em módulos de avaliação que poderão ser usados sozinhos ou reagrupados dependendo do objetivo que uma determinada empresa deseja alcançar. No próximo capítulo será realizado um estudo de caso aplicando os módulos de avaliação que foram desenvolvidos neste capítulo. 


\section{Capítulo 4}

\section{ESTUDO DE CASO}

\subsection{Considerações Iniciais}

Neste capítulo é apresentado um estudo de caso realizado na empresa Ceterp - Centrais Telefônicas de Ribeirão Preto S/A com o apoio de um método de pesquisa empírica - GQM onde foram aplicados todos os modulos de avaliaçōes desenvolvidos no capítulo anterior.

\subsection{Planejamento da Avaliação}

O estudo de caso realizado na empresa Ceterp segue os passos do método GQM que foi descrito no Capítulo 2 na Seção 2.1.2. A seguir será desenvolvido o estudo de caso.

\subsubsection{Passo1: Objetivos da Pesquisa}

Objeto: Pacotes de software em operação: a folha de paganıento e administração de recursos humanos, o controle do ponto eletrônico, o controle de materiais, o controle de contas a pagar, a contabilidade i e contabilidade ii (pois existem dois pacotes de software enı operação na área de contabilidade).

Propósito: Avaliação da adequaçāo ao ambiente empresarial, da qualidade da documentação, dos serviços de manutenção, do treinamento realizado, da documentação do treinamento, dos serviços técnicos prestados, da necessidade de atualização da versão com aplicação dos modulos de avaliaçōes desenvolvidos no capítulo anterior. 
Foco de qualidade: Características de qualidade da ISO/IEC 9126 e de outras encontradas na literatura.

Contexto: Área administrativa/financeira da empresa Ceterp. A Ceterp é uma empresa que atua em Ribeirão Preto, Bonfim Paulista e Guatapará no ramo de telecomunicações e apresenta um quadro de aproximadamente 1.150 empregados.

Perspectiva: Do usuário operacional, ou seja, de quem fornece dados para o pacote de software.

\subsubsection{Passo 2: Lista de Questões de Interesse}

O objetivo da pesquisa realizada na empresa Ceterp é a apresentação do diagnóstico da situação atual em que se encontra o parque de pacotes de software em operação na área de sistemas de informação. Para atingir esse objetivo existe a necessidade de avaliar os pacotes de softwares em operaçāo que foram comprados e possuem a assistência técnica e suporte fornecidos pelas empresas que venderam esses pacotes. Então, há a necessidade de realizar avaliações distintas para obter informaçōes para optar por um determinado tipo de tomada de decisão. Assim, as questões consideradas estão relacionadas com a adequação do pacote de software no ambiente empresarial, a qualidade da documentação, os serviços de manutenção, o treinamento realizado, a qualidade da documentação de treinamento, os serviços técnicos prestados, e a necessidade de atualizar a versão. Logo, as questões de interesse utilizadas nesse estudo de caso serão as mesmas que foram levantadas no Capítulo 3 na Seção 3.2.2.

\subsubsection{Passo 3: Métricas}

As métricas utilizadas nesse estudo empírico foram as mesmas apresentadas no Capítulo 3 na Seção 3.2.3. Cabe salientar que Belchior em sua pesquisa padronizou a escala de classificação o que facilitou a sua análise, mas os termos usados em seu questionário só poderiam ser respondidos com a ajuda de um manual que ele desenvolveu. A pesquisa do CTI usava uma métrica para as suas questões complicada para uma pessoa que não era técnica da área de informática. Vidal utilizou da classificação e hierarquização de frases por realizar uma pesquisa exploratória. Pode-se como uma 
alternativa de trabalho futuro padronizar a escala de classificaçāo como no trabalho de Belchior. Assim, seria usada uma única escala nas perguntas do questionário.

\subsubsection{Passo 4: Projeto e Teste do Questionário de Coleta de Dados}

Foi realizado um teste piloto onde foi solicitado que dois participantes preenchessem o questionário. $O$ preenchimento do questionário foi discutido com os fornecedores de dados, para verificar a existência de perguntas poucas claras.

A versão final do questionário encontra-se no Anexo 1.

\subsubsection{Passo 5: Coleta e Validação dos Dados}

A coleta ocorreu no período de janeiro até março de 1998, através de entrevistas que foram realizadas pessoalmente. Foi elaborada uma lista de usuários e através dessa lista houve uma seleção dos usuários que responderiam o questionário. Assim, foram escolhidos aqueles que tinham um grande contato com o pacote de software. As entrevistas foram iniciadas fazendo-se uma breve introdução dos objetivos da pesquisa e de sua importância para o entrevistado explicando a representação de cada módulo do questionário no contexto da empresa, ajudando o entrevistado a selecionar os módulos que seriam respondidos por ele. As entrevistas ocorreram nos proprios setores dos usuários e foi consentida a liberdade para os usuários fazer observações sobre os pacotes de software em questão.

A validação dos dados verificou os módulos do questionário quanto à consistência. Como as entrevistas foram realizadas pessoalmente todos os problemas detectados no questionário foram resolvidos na hora.

\subsubsection{Passo 6: Análise dos Dados}

Neste tópico são apresentadas as estatísticas básicas (mínimo, máximo, média, desvio padrāo) dos dados obtidos em cada uma das variáveis definidas para a pesquisa. A análise estatística dos resultados foi realizada através do pacote de software estatístico SPSS for Windows Student 
Version [SPS96]. A Tabela 4.1 apresentada abaixo mostra a quantidade de entrevistados por cada pacote de software pesquisado na empresa Ceterp S/A.

Tabela 4.1 Quantidade de Entrevistados por Pacotes de Softwares

\begin{tabular}{|l|r|}
\hline Pacotes de Softwares & Quantidade de Entrevistados \\
\hline Folha de pagamento e administração de recursos humanos & 5 \\
\hline Controle de ponto eletrônico & 2 \\
\hline Contabilidade i & 3 \\
\hline Contabilidade ii & 2 \\
\hline Controle de materiais & 4 \\
\hline Controle de contas a pagar & 3 \\
\hline Totais de entrevistados por pacotes de softwares & 19 \\
\hline
\end{tabular}

A Tabela 4.2 apresentada abaixo mostra a quantidade de entrevistados por cada modulo de avaliação e por cada pacote de software pesquisado.

Tabela 4.2 Quantidade de Entrevistados por Módulos de Avaliação

\begin{tabular}{|c|c|c|c|c|c|c|c|}
\hline \multirow[b]{2}{*}{ Módulos de Avaliação } & \multicolumn{7}{|c|}{ Pacotes de Software } \\
\hline & 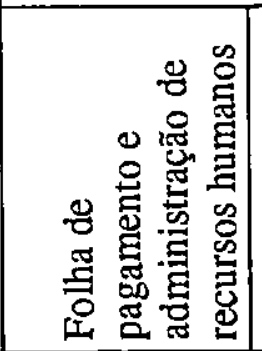 & 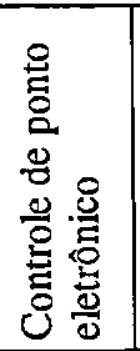 & 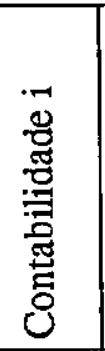 & 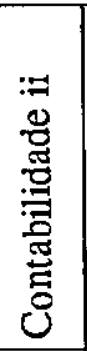 & 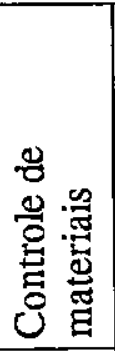 & 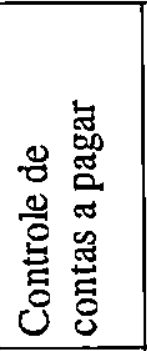 & 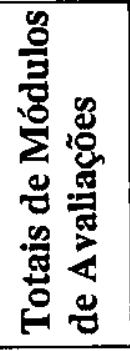 \\
\hline 1 Adequação & 5 & 2 & 3 & 2 & 4 & 3 & 19 \\
\hline 2 Documentação & 4 & 1 & & 1 & 3 & 2 & 11 \\
\hline 3 Serviços de manutenção & 4 & 1 & & & 1 & & 6 \\
\hline 4 Treinamento realizado & 5 & & 2 & 3 & 2 & 3 & 15 \\
\hline 5 Documentação de treinamento & 5 & & & & 2 & 3 & 10 \\
\hline 6 Serviços técnicos prestados & 4 & 1 & 1 & 2 & 1 & 3 & 12 \\
\hline 7 Atualização da versão & 5 & 1 & & 2 & & 2 & 10 \\
\hline $\begin{array}{l}\text { Totais de Módulos de Avaliações } \\
\text { Aplicados por pacotes de } \\
\text { softwares }\end{array}$ & 32 & 6 & 6 & 10 & 13 & 16 & 83 \\
\hline
\end{tabular}

As Tabelas de números 4.3 até 4.34 mostradas a seguir são as tabelas descritivas das palavras chaves obtidas do estudo de caso realizado. A legenda utilizada nas tabelas (N Quantidade de entrevistados que responderam a questão, Mínimo - Pontuação de menor peso dada 
para a questão pelo entrevistado, Máximo - Pontuação de maior peso dada para a questão pelo entrevistado, Média - Soma dos pesos atribuídos pelos entrevistados para a questão dividido pela quantidade de entrevistados (N), Desvio Padrão - É definido como a raiz quadrada da média dos quadrados dos desvios dos valores observados com relação a média). A seguir é mostrado o resultado da análise de cada pacote de software pesquisado com suas palavras chaves e por fim é apresentada a classificação dos pacotes de software analisados no contexto empresarial.

\section{Pacote de Software: Folha de Pagamento e Administração de Recursos Humanos}

A Tabela 4.3 mostra o rusultado da aplicação do Modulo de Avaliação da adequação do pacote de software ao ambiente empresarial sobre o pacote de software folha de pagamento e administração de recursos humanos e a seguir será comentado o resultado desta tabela.

Tabela 4.3 Módulo 1 Adequação - Pacote de Software: Folha de Pagamento e Administração de Recursos Humanos

\begin{tabular}{|c|c|c|c|c|}
\hline \multicolumn{5}{|c|}{ Módulo 1 Adequação - Pacote de Software: Folha de Pagamento e Administração de RH } \\
\hline $\begin{array}{ll}\text { Palavra Chave } & N=5\end{array}$ & Mínimo & Máximo & Média & Desvio Padrăa \\
\hline M1-1 Satisfação do usuário & 2 & 3 & 2,60 & 0,55 \\
\hline M1-2 Completitude & 2 & 3 & 2,80 & 0,45 \\
\hline M1-3 Fluxos de informaçōes, processos & 2 & 5 & 2,80 & 1,30 \\
\hline M1-4 Exatidão dos dados & 1 & 4 & 1,80 & 1,30 \\
\hline M1-5 Importar dados & 2 & 2 & 2,00 & 0,00 \\
\hline M1-6 Exportar dados & 2 & 2 & 2,00 & 0,00 \\
\hline M1-7 Acesso ao software & 5 & 5 & 5,00 & 0,00 \\
\hline M1-8 Outras pessoas utilizam sua área de trabalho & 1 & 5 & 4,00 & 1,73 \\
\hline M1-9 Confiança & 1 & 2 & 1,80 & 0,45 \\
\hline M1-10 Interpretação dos dados & 2 & 5 & 2,75 & 1,50 \\
\hline M1-11 Abrangência do conhecimento & 2 & 3 & 2,40 & 0,55 \\
\hline M1-12 Outros softwares similares & 3 & 5 & 4,60 & 0,89 \\
\hline M1-13 Facilidade de utilização & 1 & 2 & 1,80 & 0,45 \\
\hline M1-14 Operaçāo do software & 2 & 3 & 2,20 & 0,45 \\
\hline M1-15 Tempo de processamento das funções & 3 & 3 & 3,00 & 0,00 \\
\hline M1-16 Velocidade do software & 3 & 4 & 3,20 & 0,45 \\
\hline M1-17 Tempo de impressão & 3 & 4 & 3,60 & 0,55 \\
\hline M1-18 Instalação do software & 2 & 2 & 2,00 & 0,00 \\
\hline
\end{tabular}

Módulo 1 Adequação ao Ambiente Empresarial - Pacote de Software: Folha de Pagamento e Administração de Recursos Humanos 
Cinco pessoas que operam o pacote de software foram entrevistadas nesse Modulo de Avaliação e todas responderam o questionário. Dos cinco entrevistados, dois sāo da seção de Administração de Recursos Humanos, dois da seção de Registro e Pagamento e um da seção de Benefícios, Segurança e Saúde Ocupacional. As palavras chaves estão agrupadas pela pontuação mínima e máxima. Os pesos mais baixos estão próximos da pontuação ideal com exceção das palavras chaves M1-7 Acesso ao software e Ml-8 Outras pessoas utilizam sua área de trabalho que a pontuação mais alta é a ideal.

A satisfação do usuário, completitude, abrangência do conhecimento e operação do software receberam um peso variando de 2 até 3. Isto significa que os usuários estão divergindo em suas opiniões. Alguns usuários verificam a necessidade de melhora no pacote de software para atender as palavras chaves e outros estão satisfeitos com o pacote de software que eles usam. A divergência das opiniões neste caso está relacionada com a área operacional do usuário em que o módulo do pacote de software não está adequado. As funções que eles necessitam poucas vezes estão disponíveis no pacote de software para realização de suas tarefas. Verifica-se que eles possuem um bom conhecimento do pacote de software que operam, conhecendo quase que todo o pacote de software.

Fluxo de informações e processos, interpretação dos dados receberam um peso variando de 2 até 5 . Isto signifíca que a realidade da empresa não está retratada fielmente no pacote de software pois o pacote não atende o fluxo de informaçōes e os processos da área de administração de recursos humanos e a interpretação de mensagens do sistema é de difícil entendimento apenas para um usuário porque uma grande parte delas, quando ocorre algum tipo de erro, é dirigida para o analista de sistemas.

A exatidão de dados recebeu um peso variando de 1 até 4 . Isto mostra que os dados referentes a área de administração de recursos de humanos precisa ser atualizada, pois foi a área de onde foi encontrada a maior pontuação, portanto a empresa necessita de criar um plano de atualização dos dados, principalmente na parte de cadastros.

Importar dados, exportar dados e instalação do software houve um consenso e receberam um peso 2, ou seja, os usuários não conseguem realizar essas atividades sem o auxílio do analista do sistema. 
Acesso ao software houve um consenso e recebeu o peso 5, ou seja, os entrevistados não permitem que outras pessoas conheçam a sua senha. Isto torna o ambiente mais seguro, pois o pacote de software possui mecanismos de segurança, garantindo a proteção das informações geradas, não permitindo que essas informações sejam acessadas e modificadas pelos usuários não autorizados.

Confiança e facilidade de utilização receberam um peso variando de 1 até 2, ou seja, mostra que os usuários acham o pacote de software confiável, isto 6 , quase que não ocorre falhas. A opinião dos usuários é que o software é fácil de utilizar, pois possui teclas de atalho e padronização de telas e tcclas de funções permitindo uma interface amigável.

Outras pessoas utilizam sua área de trabalho recebeu um peso variando de 1 até 5, ou seja, existem poucos usuários que saem da sala de trabalho e deixam sua máquina ligada com acesso ao pacote de software permitindo que outros usuários utilizem o pacote de software e até realizem transações com o seu nome. Precisa existir uma conscientização por parte destes usuários para que as informações registradas no pacote de software mantenham-se confidenciais e confiáveis.

Outros softwares similares recebeu um peso variando de 3 até 5 , ou seja, são poucos os usuários que conhecem um outro pacote de software similar. A maioria dos usuários conhecem só o pacote de software que utilizam.

Tempo de processamento das funções recebeu em consenso o peso 3, ou seja, o usuário avalia como bom o tempo de processamento das funçōes do pacote de software.

A velocidade do software e tempo de impressão receberam um peso variando de 3 ate 4 , ou seja, isto mostra a insatisfação dos usuários com a velocidade do software e com o tempo de impressão dos seus relatórios, precisando de uma maior atenção pela empresa para essas palavras chaves, principalmente com a palavra chave tempo de impressão.

Comentários: De acordo com os resultados acima pode-se sugerir a criação de um plano a ser desenvolvido pela área de Recursos Humanos para a atualização periódica do cadastro do empregado, principalmente no que refere-se ao endereço e cursos realizados pelos empregados. Verifica-se a necessidade de um estudo para a implementação de funções que atendam a área de Administração de Recursos Humanos ou até mesmo como alternativa a compra de um sistema informatizado para esta área. Também verifica-se a necessidade de um estudo para a compra de 
uma ferramenta que auxilie os usuários na extração de dados e possibilite confecção de relatórios permitindo uma maior liberdade na manipulação dos dados. Recomenda-se que os usuários visitem outras empresas para conhecer o mesmo e até outros pacotes de software da área funcionando, além disso, assistir as demonstrações de pacotes de software realizadas pelos vendedores. Também verifica-se uma insatisfação do usuário quanto ao local em que são impressos os relatórios, ou seja, eles desejariam que os relatórios fossem impressos na própria área de recursos humanos, garantindo uma otimização no fluxo de informações e privacidade dos dados impressos.

A Tabela 4.4 apresenta o resultado da aplicação do Módulo de Avaliação da qualidade da documentação (manual do usuário) sobre o pacote de software folha de pagamento e administração de recursos humanos e será comentado o resultado desta tabela.

\section{Tabela 4.4 Módulo 2 Documentação - Pacote de Software: Folha de Pagamento e Administração de Recursos Humanos}

\begin{tabular}{|l|r|r|r|r|r|}
\hline Módulo 2 Documentação - Pacote de Software: Folha de Pagamento e Administração de RH \\
\hline Palavra Chave & N & Mínimo & Máximo & Média & Desvio Padrão \\
\hline M2-1 Completitude & 4 & 1 & 2 & 1,75 & 0,50 \\
\hline M2-2 Consistência & 4 & 1 & 2 & 1,75 & 0,50 \\
\hline M2-3 Exatidão & 4 & 1 & 2 & 1,50 & 0,58 \\
\hline M2-4 Interface & 4 & 6 & 7 & 6,75 & 0,50 \\
\hline M2-5 Organização & 4 & 1 & 2 & 1,25 & 0,50 \\
\hline M2-6 Apresentação visual & 4 & 2 & 4 & 3,00 & 0,82 \\
\hline M2-7 Clareza & 4 & 2 & 3 & 2,25 & 0,50 \\
\hline M2-8 Exemplos & 4 & 2 & 5 & 3,00 & 1,41 \\
\hline M2-9 Iustrações & 4 & 1 & 5 & 3,00 & 1,63 \\
\hline M2-10 Fácil localização & 4 & 1 & 1 & 1,00 & 0,00 \\
\hline M2-11 Glossário & 4 & 2 & 2 & 2,00 & 0,00 \\
\hline M2-12 Referências cruzadas & 4 & 1 & 2 & 1,75 & 0,50 \\
\hline M2-13 Consultas adicionais de bibliografia & 4 & 1 & 2 & 1,75 & 0,50 \\
\hline M2-14 Manuseio & 4 & 2 & 3 & 2,50 & 0,58 \\
\hline M2-15 Manual de instalação do software & 1 & 2 & 2 & 2,00 & 0,00 \\
\hline M2-16 Requisitos de hardware & 1 & 2 & 2 & 2,00 & 0,00 \\
\hline M2-17 Instalação & 2 & 2 & 2 & 2,00 & 0,00 \\
\hline
\end{tabular}

Módulo 2 Qualidade da Documentação - Pacote de Software: Folha de Pagamento e Administração de Recursos Humanos

Quatro pessoas que operam o pacote de software foram entrevistadas nesse Módulo de Avaliação e todas responderam o questionário, com exceção das palavras chaves $M$ 2-15 Manual de instalação do software e M2-16 Requisitos de hardware (apenas um usuário) e M2-17 Instalação 
(apenas dois usuários). Dos quatro entrevistados, dois são da seção de Administração de Recursos Humanos, um é da seção de Registro e Pagamento e um da seção de Benefícios, Segurança e Saúde Ocupacional. As palavras chaves estão agrupadas pela pontuação mínima e máxima. Os pesos mais baixos estão próximos da pontuação ideal.

Completitude, consistência, exatidão, organização receberam um peso variando de 1 até 2 . Isto significa que quase todas as funções estão descritas no pacote de software e as informações estão livres de ambiguidades e tambêm a maioria das informações estão corretas para operação e funcionamento do pacote de software e o texto está bem organizado.

Interface, consultas adicionais de bibliografia, referências cruzadas receberam uma pontuação variando de 1 até 2 . Isto mostra que algum usuário procurou saber a respeito ou precisou utilizar e encontrou descrito ou presente na documentação a palavra chave.

Apresentação visual recebeu um peso variando de 2 até 4, ou seja, o usuário considera que o manual necessita de uma melhora em relação aos itens cores, figuras, gráficos e a qualidade do papel.

Clareza e manuseio receberam um peso variando de 2 até 3 , ou seja, o usuário encontra dificuldade em entender o texto da documentação e acha que poderia ocorrer uma melhora no aspecto da forma do manual, tamanho e peso, pois o manual é muito grande e pesado.

Exemplos recebeu um peso variando de 2 até 5, ou seja, houve uma discordância de opiniōes pois alguns usuários acham que deveriam existir mais exemplos e outros que os existentes são suficientes para o seu entendimento, precisando existir uma melhora nesta palavra chave para atender a todos os usuários.

Ilustraçôes recebeu um peso variando de 1 até 5 , ou seja, houve uma discordância de opiniões entre os usuários entrevistados, onde alguns acham que as existentes são suficientes e outros que precisariam existir mais ilustraçōes, necessitando de uma melhora nesta palavra chave para atender a todos os usuários.

Fácil localização recebeu em consenso o peso 1, ou seja, o usuário encontra com muita facilidade as informações que deseja, pois a tela do pacote de software possui um número em seu 
lado direito inferior que corresponde a página do manual do usuário e este número também referese a função.

Glossário, manual de instalação do software, requisitos de hardware, instalação em consenso receberam o peso 2 , ou seja , eles não foram identificadas pelo usuário na documentação.

Comentários: Pode-se notar que necessita ocorrer uma melhora na qualidade da documentação no que refere-se ao manuseio, apresentação visual, exemplos e ilustrações. Para facilitar o manuseio sugere-se que o manual seja dividido por capítulos correspondentes as áreas do recursos humanos e cada capítulo se tornaria um outro livro, assim cada área teria seu manual tornando-o mais leve para carregar e também para que fique menor deveria diminuir o tamanho de suas páginas.

A Tabela 4.5 mostra o resultado da aplicação do Módulo de Avaliação dos serviços de manutenção prestados pela empresa fornecedora sobre o pacote de software folha de pagamento e administração de recursos humanos e a seguir será comentado o resultado desta tabela.

Tabela 4.5 Módulo 3 Serviços de Manutenção - Pacote de Software: Folha de Pagamento e Administração de Recursos Humanos

\begin{tabular}{|l|r|r|r|r|r|}
\hline $\begin{array}{l}\text { Módulo 3 Serviços de Manutenção - Pacote de Software: Folha de Pagamento e } \\
\text { Administração de Recursos Humanos }\end{array}$ \\
\hline Palavra Chave & N & \multicolumn{1}{|l|}{ Mínimo } & Máximo & Média & \multicolumn{1}{l|}{ Desvio Padrão } \\
\hline M 3-1 Atualização da documentação & 4 & 1 & 2 & 1,50 & 0,58 \\
\hline $\begin{array}{l}\text { M3-2 Atualização do software em tempo } \\
\text { hábil para solução do problema }\end{array}$ & 3 & 3 & 5 & 3,67 & 1,15 \\
\hline M3-3 Novas versões & 3 & 1 & 2 & 1,67 & 0,58 \\
\hline
\end{tabular}

\section{Módulo 3 Serviços de Manutenção - Pacote de Software: Folha de Pagamento e Administração de Recursos Humanos}

Quatro pessoas que operam o pacote de software foram entrevistadas nesse Módulo de Avaliação e todas responderam o questionário, com exceção das palavras chaves M3-2 Atualização do software em tempo hábil para solução do problema e M3-3 Novas versões (apenas três usuários). Dos quatro entrevistados, dois são da seção de Administração de Recursos Humanos, um é da seção de Registro e Pagamento e um da seção de Benefícios, Segurança e Saúde Ocupacional. Os pesos mais baixos estão próximos da pontuação ideal. 
Atualização da documentação recebeu um peso variando de 1 até 2 , ou seja, alguns usuários já receberam a atualização da documentação enquanto outros não tomaram conhecimento desta atualização. A atualização do software em tempo hábil para solução do problema recebeu um peso de 3 até 5, ou seja, alguns usuários conseguiram ser atendidos em seus pedidos de manutenção pela empresa fornecedora do software enquanto que alguns pedidos de manutenção ainda não foram atendidos. A palavra chave novas versões recebeu um peso variando de 1 até 2 , isto é, alguns usuários disseram que a empresa disponibiliza as novas versões enquanto os outros que não, ou seja, o usuário não percebeu a mudança de versão ocorrida no pacote de software, pois essas mudanças talvez não tenham atingindo a sua área dentro da empresa.

Comentário: Um sugestāo é que empresa prestadora de serviços de manutenção deveria manter o mesmo nível de qualidade para todas as áreas dentro do recursos humanos, um exemplo a ser citado é o setor da folha de pagamento versus o setor da administração de recursos humanos. Observa-se que a empresa prestadora de serviço prioriza o modulo folha de pagamento.

A Tabela 4.6 apresenta o resultado da aplicação do Módulo de Avaliação do treinamento realizado sobre o pacote de software folha de pagamento e administração de recursos humanos e a seguir será comentado o resultado desta tabela.

Tabela 4.6 Módulo 4 Treinamento - Pacote de Software: Folha de Pagamento e Administração de Recursos Humanos

\begin{tabular}{|l|r|r|r|r|r|}
\hline Módulo 4 Treinamento - Pacote de Software: Folha de Pagamento e Administração de RH \\
\hline Palavra Chave & N & \multicolumn{1}{|c|}{ Mínimo } & Máximo & \multicolumn{1}{c|}{ Médla } & Desvio Padrão \\
\hline M4-1 Completitude & 5 & 2 & 2 & 2,00 & 0,00 \\
\hline M4-2 Consistência & 5 & 1 & 3 & 1,60 & 0,89 \\
\hline M4-3 Cronograma & 5 & 2 & 3 & 2,80 & 0,45 \\
\hline M4-4 Satisfação com o treinamento & 5 & 2 & 3 & 2,60 & 0,55 \\
\hline M4-5 Exatidão das informaçōes & 5 & 1 & 3 & 1,80 & 0,84 \\
\hline M4-6 Organização da apresentação & 5 & 1 & 2 & 1,60 & 0,55 \\
\hline M4-7 Apresentação visual & 5 & 6 & 7 & 6,40 & 0,55 \\
\hline M4-8 Clareza, oratória & 5 & 2 & 3 & 2,20 & 0,45 \\
\hline M4-9 Exemplos & 5 & 2 & 3 & 2,40 & 0,55 \\
\hline M4-10 Ilustrações & 5 & 1 & 3 & 2,20 & 0,84 \\
\hline M4-11 Funções aprendidas e exercitadas & 5 & 1 & 3 & 2,20 & 0,84 \\
\hline M2-12 Consulta adicional de bibliografia & 5 & 7 & 8 & 7,20 & 0,45 \\
\hline M4-13 Freqüência de falhas & 5 & 2 & 3 & 2,60 & 0,55 \\
\hline M4-14 Gravidade da falha & 5 & 6 & 7 & 6,20 & 0,45 \\
\hline
\end{tabular}




\section{Módulo 4 Treinamento Realizado - Pacote de Software: Folha de Pagamento e Administração de Recursos Humanos}

Cinco pessoas que operam o pacote de software foram entrevistadas nesse M6dulo de Avaliação e todas responderam o questionário. Dos cinco entrevistados, dois são da seção de Administração de Recursos Humanos, dois da seção de Registro e Pagamento e um da seção de Benefícios, Segurança e Saúde Ocupacional. As palavras chaves estão agrupadas pela pontuação mínima e máxima. Os pesos mais baixos estão próximos da pontuação ideal com exceção das paldavras chaves M4-13 Freqüência de falhas e M4-14 Gravidade da falha que a pontuação mais alta é a ideal.

Completitude recebeu em consenso o peso 2 , ou seja, a maioria das funçōes foram apresentadas no treinamento.

As palavras chaves consistência, exatidão das informações, ilustrações, funções aprendidas $e$ exercitadas receberam um peso variando de 1 ate 3 . Isto mostra que estas palavras chaves necessitam ainda ser melhoradas para a satisfação do usuário.

Cronograma, satisfação com o treinamento, clareza e oratória, exemplos, freqüiência de falhas receberam um peso variando de 2 ate 3 , ou seja, o cronograma precisaria ser melhor planejado e junto com o usuário, além disso, ocorreram falhas durante o treinamento, e alguns entrevistados não ficaram satisfeitos com a explanação do instrutor, e poderia existir uma melhora nos exemplos utilizados direcionando-os para o contexto da empresa.

Organização da apresentação recebeu um peso variando de 1 ate 2 , ou seja, a apresentação do treinamento ocorreu de forma bem organizada.

Apresentação visual recebeu um peso variando de 6 ate 7 , ou seja, o instrutor poderia utilizar de mais recursos para a sua apresentação para agradar a todos os usuários.

Consulta adicional de bibliografia recebeu o peso 7 , ou seja, não houve pelo instrutor indicações de livros ou empresas para o usuário buscar mais informações sobre o assunto discorrido para complementação do treinamento ou maior esclarecimento de alguma dúvida que tenha surgido.

Gravidade da falha recebeu um peso variando de 6 ate 7 , ou seja, alguns usuários sentiram prejudicados, pois a falha ocorrida prejudicou o treinamento. 
Comentário: A sugestão a ser dada é a contratação de um novo treinamento mais avançado para as pessoas que já utilizam o pacote de software considerando a participação delas na elaboração do cronograma e no assunto a ser revisto.

A Tabela 4.7 apresenta o resultado da aplicação do Módulo de Avaliação da documentação de treinamento e após será comentado o resultado desta tabela.

Tabela 4.7 Módulo 5 Documentação de Treinamento - Folha de Pagamento e Administração de Recursos Humanos

\begin{tabular}{|l|r|r|r|r|r|}
\hline Módulo 5 Documentação de Treinamento - Pacote de Software: Folha de Pagamento e RH \\
\hline Palavra Chave & N & \multicolumn{1}{|c|}{ Mínimo } & Máximo & Média & Desvio Padrão \\
\hline M5-1 Índices & 5 & 6 & 6 & 6,00 & 0,00 \\
\hline M5-2 Glossário & 5 & 7 & 7 & 7,00 & 0,00 \\
\hline M5-3 Referências cruzadas & 3 & 7 & 8 & 7,40 & 0,55 \\
\hline M5-4 Consultas adicionais bibliográficas & 4 & 7 & 8 & 7,20 & 0,45 \\
\hline M5-5 Manuseio & 5 & 1 & 2 & 1,80 & 0,45 \\
\hline
\end{tabular}

Módulo 5 Documentação de Treinamento - Pacote de Software: Folha de Pagamento e Administração de Recursos Humanos

Cinco pessoas que operam o pacote de software foram entrevistadas nesse Módulo de Avaliação e todas responderam o questionário, com exceção das palavras chaves M5-3 Referências cruzadas (apenas 3 usuários) e M5-4 Consultas adicionais bibliográficas (apenas 4 usuários). Dos cinco entrevistados, dois são da seção de Administração de Recursos Humanos, dois da seçāo de Registro e Pagamento e um da seção de Beneffcios, Segurança e Saúde Ocupacional. Os pesos mais baixos estão próximos da pontuação ideal.

Índices recebeu o peso 6, ou seja, a documentação do treinamento possuía índices. Glossário recebeu o peso 7, ou seja, que a documentação do treinamento nāo possuía glossário dos termos técnicos. As palavras chaves referências cruzadas e consultas adicionais de bibliografia receberam o peso 7, ou seja, os entrevistados verificaram que o treinamento não continha estas palavras chaves. Manuseio recebeu um peso variando de 1 até 2 , ou seja, os usuários estão satisfeitos com a forma da documentação do treinamento.

Comentário: De modo geral, os usuários ficaram satisfeitos com a documentação do treinamento. 
A Tabela 4.8 apresentada abaixo mostra o resultado da aplicação do Módulo de Avaliação dos serviços técnicos prestados pela empresa fornecedora sobre o pacote de software folha de pagamento e administração de recursos humanos e a seguir será comentado o resultado desta tabela.

Tabela 4.8 Módulo 6 Serviços Técnicos - Pacote de Software: Folha de Pagamento e Administração de Recursos Humanos

\begin{tabular}{|c|c|c|c|c|c|}
\hline \multicolumn{6}{|c|}{$\begin{array}{l}\text { Módulo } 6 \text { Serviços Técnicos Prestados - Pacote de Software: Folha de Pagamento e } \\
\text { Administração de Recursos Humanos }\end{array}$} \\
\hline Palavra Chave & $\mathbf{N}$ & Mínimo & Máximo & Média & Desvio Padrão \\
\hline M6-1 Alendimento pelo fornecedor & 4 & 1 & 3 & 2,50 & $\begin{array}{r}1,00 \\
\end{array}$ \\
\hline M6-2 Contato telefônico & 4 & 2 & 4 & 3,00 & 0,82 \\
\hline M6-3 Tempo hábil para solução do problema & 4 & 3 & 4 & 3,25 & 0,50 \\
\hline
\end{tabular}

Módulo 6 Serviços Técnicos Prestados - Pacote de Software: Folha de Pagamento e Administração de Recursos Humanos

Quatro pessoas que operam o pacote de software foram entrevistadas nesse Módulo de Avaliação e todas responderam o questionário. Dos quatro entrevistados, dois são da seção de Administração de Recursos Humanos, um é da seção de Registro e Pagamento e um da seção de Benefícios, Segurança e Saúde Ocupacional. Os pesos mais baixos estão próximos da pontuação ideal.

Atendimento pelo fornecedor recebeu peso variando de 1 até 3 , ou seja, os usuários estão satisfeitos com o serviço técnico prestado pela empresa fornecedora do pacote de software. $\mathrm{O}$ contato telefônico recebeu um peso variando de 2 até 4, ou seja, o atendimento telefônico precisa ser melhorado. O tempo hábil para solução do problema recebeu um peso variando de 3 até 4 , ou seja, o usuário da área de administração de recursos humanos está insatisfeito com o tempo para as soluções de seus problemas pela empresa fornecedora do pacote de software, pois a empresa entregou fora do prazo uma solicitação sua.

Comentário: Verifica-se que o serviço técnico prestado pela empresa fornecedora do pacote de software precisa ser revisto principalmente na palavra chave tempo hábil para a solução do problema. 
A Tabela 4.9 apresentada mostra o resultado da aplicação do Módulo de Avaliaçāo da atualização de versão do pacote de software sobre o pacote de software folha de pagamento e administração de recursos humanos e a seguir será comentado o resultado desta tabela.

Tabela 4.9 Módulo 7 Atualização da Versão - Pacote de Software: Folha de Pagamento e Administração de Recursos Humanos

\begin{tabular}{|c|c|c|c|c|c|}
\hline \multicolumn{6}{|c|}{$\begin{array}{l}\text { Módulo } 7 \text { Atualização da Versão - Pacote de Software: Folha de Pagamento e } \\
\text { Administração de Recursos Humanos }\end{array}$} \\
\hline Palavra Chave & $\mathbf{N}$ & Mínimo & Máximo & Média & Desvio Padrão \\
\hline M7-1 Implantação da nova versão & 5 & 6 & 7 & 6,40 & 0,55 \\
\hline M7-2 Necessidade de novas funções & 5 & 1 & 2 & 1,20 & 0,45 \\
\hline M7-3 Melhoria nas funções existentes & 4 & 1 & 8 & 4,80 & 3,27 \\
\hline M7-4 Substituição de funções & 4 & 6 & 8 & 7,40 & 0,89 \\
\hline M7-5 Mudanças de processos & 4 & 1 & 8 & 2,80 & 2,95 \\
\hline M7-6 Automatização de processos & 4 & 2 & 8 & 4,00 & 2,45 \\
\hline M7-8 Teste da nova versão & 4 & 6 & 8 & 6,60 & 0,89 \\
\hline
\end{tabular}

Módulo 7 Atualização de Versão do Pacote de Software - Pacote de Software: Folha de Pagamento e Administração de Recursos Humanos

Cinco pessoas que operam o pacote de software foram entrevistadas nesse Módulo de Avaliação e todas responderam o questionário e as palavras chaves M7-1 Implantação da nova versäo e M7-2 Necessidade de novas funções e as outras palavras chave foram respondidas por apenas 4 usuários. Dos cinco entrevistados, dois são da seção de Administração de Recursos Humanos, dois da seção de Registro e Pagamento e um da seção de Benefícios, Segurança e Saúde Ocupacional. Os pesos mais baixos estão próximos da pontuação ideal.

Implantação da nova versão recebeu um peso variando de 6 até 7, ou seja, a maior parte dos usuários entendem que o momento é adequado para implantação de uma nova versāo do pacote de software.

Necessidade de novas funções recebeu um peso variando de 1 até 2 , ou seja, o usuário necessita da implementação de novas funçōes.

Uma grande parte dos usuários acredita que a nova versão do pacote de software vai acrescentar melhoria nas funçôes existentes do pacote de software. 
Substituição de funções: apenas um usuário acredita que a nova versão substituirá alguma função existente.

Mudanças de processos: no momento atual está ocorrendo várias mudanças no setor do usuário que talvez o pacote de software não conseguirá atender.

Automatização de processos: grande parte dos processos estão automatizados na seção de Registro e Pagamento e falta automatizar alguns processos da seção de Administração de Recursos Humanos.

Teste da nova versão: a maioria dos usuários tem conhecimento que a nova versão a ser implantada na empresa já foi implantada por outras empresas.

Comentário: Como sugestão é preciso verificar os processos que necessitam ser automatizados e realizar um estudo das mudanças que estão ocorrendo. Pode-se concluir que o momento é adequado para efetuar a atualização de versão do pacote de software.

\section{Pacote de Software: Controle de Ponto Eletrônico}

A Tabela 4.10 apresentada mostra o resultado da aplicação do Modulo de Avaliação da adequação do pacote de software ao ambiente empresarial sobre o pacote de software controle de ponto eletrônico e será comentado o resultado desta tabela.

\section{Módulo 1 Adequação - Pacote de Software: Controle de Ponto Eletrônico}

Duas pessoas que operam o pacote de software foram entrevistadas nesse Modulo de Avaliação e responderam todas as questōes do questionário. Os dois entrevistados são da seção de Registro e Pagamento. As palavras chaves estão agrupadas pela pontuação mínima e máxima. Os pesos mais baixos estão próximos da pontuação ideal com exceção das palavras chaves $M$ 1-7 Acesso ao software e M1-8 Outras pessoas utilizam sua área de trabalho que a pontuação mais alta é a ideal.

Satisfação do usuário, completitude receberam um peso variando de 2 ate 3 , ou seja, os usuários estão satisfeitos com o pacote de software e as suas funções cobrem na maioria 0 que 0 usuário deseja para executar suas tarefas. $O$ usuário que deu a pontuação 3 comentou que não 
conhece todas as funções oferecidas pelo pacote de software pois não participou do treinamento do pacote de software.

Fluxos de informações e processos, confiança, facilidade de utilização receberam em consenso o peso 2 , ou seja, o usuário percebe que o pacote de software está próximo da realidade da empresa, ele confia no pacote de software e julga o software fácil de usar.

Tabela 4.10 Módulo 1 Adequação - Pacote de Software: Controle de Ponto Eletrônico

\begin{tabular}{|c|c|c|c|c|}
\hline \multicolumn{5}{|c|}{ Módulo 1 Adequação - Pacote de Software: Controle de Ponto Eletrônico } \\
\hline Palavra Chave $\quad \mathrm{N}=2$ & Mínimo & Máximo & Média & Desvio Padrão \\
\hline M1-1 Satisfação do usuário & 2 & 3 & 2,50 & $0, \overline{71}$ \\
\hline M1-2 Completitude & 2 & 3 & 2,50 & 0,71 \\
\hline M1-3 Fluxos de informações, processos & 2 & 2 & 2,00 & 0,00 \\
\hline M1-4 Exatidão dos dados & 1 & 2 & 1,50 & 0,71 \\
\hline M1-5 Importar dados & 2 & 2 & 2,00 & 0,00 \\
\hline M1-6 Exportar dados & 2 & 2 & 2,00 & 0,00 \\
\hline M1-7 Acesso ao software & 5 & 5 & 5,00 & 0,00 \\
\hline M1-8 Outras pessoas utilizam sua área de trabalho & 1 & 1 & 1,00 & 0,00 \\
\hline M1-9 Confiança & 2 & 2 & 2,00 & 0,00 \\
\hline M1-10 Interpretação dos dados & 1 & 2 & 1,50 & 0,71 \\
\hline M1-11 Abrangência do conhecimento & 1 & 2 & 1,50 & 0,71 \\
\hline M1-12 Outros softwares similares & 1 & 3 & 2,00 & 1,41 \\
\hline M1-13 Facilidade de utilização & 2 & 2 & 2,00 & 0,00 \\
\hline M1-14 Operação do software & 1 & 2 & 1,50 & 0,71 \\
\hline M1-15 Tempo de processamento das funções & 3 & 3 & 3,00 & 0,00 \\
\hline M1-16 Velocidade do software & 3 & 4 & 3,50 & 0,71 \\
\hline M1-17 Tempo de impressão & 3 & 3 & 3,00 & 0,00 \\
\hline M1-18 Instalação do software & 1 & 2 & 1,50 & 0,71 \\
\hline
\end{tabular}

Exatidão de dados, interpretação dos dados, abrangência de conhecimento, operação do software receberam um peso variando de 1 ate 2 , ou seja, uma boa pontuação, significando que o pacote de software foi bem avaliado para essas palavras chaves.

Importar dados, exportar dados receberam em consenso o peso 2, ou seja, o usuário não consegue sem a intervenção do analista de sistemas importar ou exportar os dados caso ele necessite.

Acesso ao software recebeu em consenso o peso 5, ou seja, o usuário não divulgou para outras pessoas a sua senha de acesso ao pacote de software. 
Outras pessoas utilizam sua área de trabalho recebeu o peso 1 , ou seja, várias pessoas do setor que o entrevistado trabalha acessam o pacote de software e realizam transações com o nome do entrevistado, isto é muito perigoso pois podem ser feitas modificações que poderão afetar a empresa e não serem descobertas as pessoas que realizaram essas alterações.

Outros softwares similares recebeu um peso variando de 1 ate 3 , pois os entrevistados conhecem no mercado outros softwares similares e isto é muito bom para serem feitas comparações entre os pacotes de software existentes no mercado e o que a empresa utiliza, trazendo um ganho para a cmpresa.

Tempo de processamento das funçôes, tempo de impressão receberam o peso 3 , ou seja, o usuário considera que essas palavras chaves atendem as suas tarefas.

Velocidade do software recebeu um peso variando de 3 até 4, ou seja, o usuário não está satisfeito com tempo de processamento das funções, podendo esta palavra chave ser melhorada, pois o pacote de software encontra-se instalado em rede e ela pode estar influenciando em sua velocidade, segundo a opiniāo do usuário. Então necessita de uma análise para saber porquê o software está lento.

Instalação do software recebeu um peso variando de 1 até 2 , ou seja, um usuário tem conhecimento técnico para a instalação do pacote de software enquanto o outro não.

Comentários: Sugere-se a criação de uma senha específica apenas para a consulta dos dados do pacote de software por outras pessoas que não operam o sistema para garantir a segurança nesse sistema. Deve ser realizada uma análise da velocidade do pacote de software. Também cabe salientar que o usuário que opera o pacote de software possui um conhecimento de outros softwares e tem o domínio do pacote de software que utiliza. Assim, pode-se concluir pelas respostas fornecidas que este pacote de software foi bem avaliado pelos usuários que operam o software.

A Tabela 4.11 apresentada mostra o resultado da aplicaçāo do Módulo de Avaliaçāo da qualidade da documentação (manual do usuário) sobre o pacote de software controle de ponto eletrónico e será comentado o resultado desta tabela. 
Módulo 2 Qualidade da Documentação - Pacote de Software: Controle de Ponto Eletrônico

Apenas uma pessoa que opera o pacote de software foi entrevistada nesse Modulo de Avaliação e respondeu o questionário, com exceção das palavras chaves $M 2-12$ Referências Cruzadas, M2-15 Manual de instalação do software, M2-16 Requisitos de hardware e M2-17 Instalação. $\mathrm{O}$ entrevistado é da seção de Registro e Pagamento. Os pesos mais baixos estão próximos da pontuação ideal.

Completitude, consistência, organização, manuseio receberam o peso 1 , ou seja, estas palavras chaves foram bem avaliadas pelo entrevistado.

Exatidão, clareza, exemplos receberam o peso 2, ou seja, o usuário considera que a maioria das informações apresentadas na documentação são corretas para a operação e funcionamento do pacote de software e quase todo o texto é bem redigido possuindo exemplos para o seu esclarecimento.

Interface, fácil localização recebeu peso 1, ou seja, a documentação possui indicações de interface com outros sistemas e possui mecanismos como índice geral e remissivos que permite o usuário localizar rapidamente a informação desejada.

Tabela 4.11 Módulo 2 Documentação - Pacote de Software: Controle de Ponto Eletrônico

\begin{tabular}{|c|c|c|c|c|c|}
\hline \multicolumn{6}{|c|}{ Módulo 2 Documentação - Pacote de Software: Controle de Ponto Eletrônico } \\
\hline Palavra Chave & $\mathbf{N}$ & Mínimo & Máximo & Média & Desvio Padrão \\
\hline M2-1 Completitude & 1 & 1 & 1 & \begin{tabular}{|r|}
1 \\
\end{tabular} & 0,00 \\
\hline M2-2 Consistência & 1 & 1 & 1 & 1 & 0,00 \\
\hline M2-3 Exatidão & 1 & 2 & 2 & 2 & 0,00 \\
\hline M2-4 Interface & 1 & 6 & 6 & 6 & 0,00 \\
\hline M2-5 Organização & 1 & 1 & 1 & 1 & 0,00 \\
\hline M2-6 Apresentação visual & 1 & 4 & 4 & 4 & 0,00 \\
\hline M2-7 Clareza & 1 & 2 & 2 & 2 & 0,00 \\
\hline M2-8 Exemplos & 1 & 2 & 2 & 2 & 0,00 \\
\hline M2-9 Ilustraçōes & 1 & 3 & 3 & 3 & 0,00 \\
\hline M2-10 Fácil localização & 1 & 1 & 1 & 1 & 0,00 \\
\hline M2-11 Glossário & 1 & 2 & 2 & 2 & 0,00 \\
\hline M2-12 Referências cruzadas & 0 & 0 & 0 & 0 & 0,00 \\
\hline M2-13 Consultas adicionais de bibliografia & 1. & 2 & 2 & 2 & 0,00 \\
\hline M2-14 Manuseio & 1 & 1 & 1 & 1 & 0,00 \\
\hline M2-15 Manual de instalação do software & 0 & 0 & 0 & 0 & 0,00 \\
\hline M2-16 Requisitos de hardware & 0 & 0 & 0 & 0 & 0,00 \\
\hline M2-17 Instalação & 0 & 0 & 0 & 0 & 0,00 \\
\hline
\end{tabular}


Apresentação visual recebeu o peso 4, ou seja, o usuário está insatisfeito como a documentação apresenta-se.

Ilustrações recebeu o peso 3, ou seja, a documentação deveria possuir mais gráficos, desenhos, figuras, podendo ainda ser melhorada essa palavra chave.

Glossário, consultas adicionais de bibliografia receberam o peso 2, ou seja, a documentação não apresenta glossário e nem indicações de bibliografia para aprofundamento do conhecimento do usuário.

Comentário: A sugestão para a melhora na qualidade da documentação é que a empresa fornecedora do pacote de software mude a documentação no que refere-se a apresentação visual, por exemplo: cores, gráficos, figuras, qualidade do papel.

A Tabela 4.12 apresentada mostra o resultado da aplicação do Módulo de Avaliação dos serviços de manutenção prestados pela empresa fornecedora sobre o pacote de software controle de ponto eletrônico e a seguir será comentado o resultado desta tabela.

Tabela 4.12 Módulo 3 Serviços de Manutenção - Pacote de Software: Controle de Ponto Eletrônico

\begin{tabular}{|l|r|r|r|r|r|}
\hline Módulo 3 Serviços de Manutenção - Pacote de Software: Controle de Ponto Eletrônico \\
\hline Palavra Chave & N & Mínimo & \multicolumn{1}{l|}{ Máximo } & \multicolumn{1}{l|}{ Média } & \multicolumn{1}{l|}{ Desvio Padrão } \\
\hline M3-1 Atualização da documentação & 1 & 2 & 2 & 2 & 0,00 \\
\hline M3-2 Atualização do software em tempo & & & & & \\
hábil para solução do problema & 1 & 3 & 3 & 3 & 0,00 \\
\hline M3-3 Novas versões & 1 & 2 & 2 & 2 & 0,00 \\
\hline
\end{tabular}

Módulo 3 Serviços de Manutenção - Pacote de Software: Controle de Ponto Eletrônico

Apenas uma pessoa que opera o pacote de software foi entrevistada nesse Módulo de Avaliação e respondeu o questionário. O entrevistado é da seção de Registro e Pagamento.

Atualização da documentação recebeu um peso 2, ou seja, não existe a atualização da documentação. Atualização do software em tempo hábil para solução do problema recebeu um peso 3, ou seja, o usuário consegue ser atendido no prazo em seus pedidos de manutenção pela 
empresa fornecedora do software. Novas versões recebeu um peso 2, ou seja, o usuário não recebeu as novas versões do pacote de software.

Comentário: A sugestão é rever o contrato de manutenção com a empresa fornecedora do pacote de software para o envio das novas versões e da atualização da documentação.

\section{Módulo 4 Treinamento - Pacote de Software: Controle de Ponto Eletrônico}

Este módulo não foi aplicado pois a pessoa que opera o pacote de sofware atualmente não participou do processo de implantação e nem do treinamento ocorrido na época.

Módulo 5 Documentação do Treinamento - Pacote de Software: Controle de Ponto Eletrônico

Este modulo não foi aplicado pois não foi disponibilizada a documentação do treinamento para o usuário que opera atualmente o pacote de software. Além do usuário não ter sido treinado.

A Tabela 4.13 apresentada mostra o resultado da aplicação do M6dulo de Avaliação da qualidade dos serviços técnicos prestados pela empresa fornecedora sobre o pacote de software controle de ponto eletrônico e a seguir será comentado o resultado desta tabela.

Tabela 4.13 Módulo 6 Serviços Técnicos - Pacote de Software: Controle de Ponto Eletrônico

\begin{tabular}{|l|r|r|r|r|r|}
\hline Módulo 6 Serviços Técnicos - Pacote de Software: Controle de Ponto Eletrônico \\
\hline Palavra Chave & $\mathbf{N}$ & \multicolumn{1}{|c|}{ Mínimo } & Máximo & Média & Desvio Padrão \\
\hline M6-1 Atendimento pelo fornecedor & 1 & 4 & 4 & 4 & 0,00 \\
\hline M6-2 Contato telefônico & 1 & 4 & 4 & 4 & 0,00 \\
\hline M6-3 Tempo hábil para solução do problema & 1 & 3 & 3 & 3 & 0,00 \\
\hline
\end{tabular}

Módulo 6 Serviços Técnicos - Pacote de Software: Controle de Ponto Eletrônico

Apenas uma pessoa que opera o pacote de software foi entrevistada nesse Modulo de Avaliação e respondeu o questionário. O entrevistado é da seção de Registro e Pagamento. Os pesos mais baixos estão próximos da pontuação ideal.

Atendimento pelo fornecedor, contato telefônico receberam o peso 4 . Isto significa que o entrevistado está insatisfeito com a empresa fornecedora do pacote de software apesar do tempo 
hábil para a solução do problema receber o peso 3 , ou seja, o seu problema ter sido solucionado no prazo.

Comentário: A empresa fornecedora do pacote de software precisa melhorar os serviços técnicos prestados disponibilizando pessoal melhor preparado e treinado para atender o usuário.

A Tabela 4.14 apresentada mostra o resultado da aplicação do modulo de avaliação da atualização de versão sobre o pacote de software controle de ponto eletrônico e a seguir será comentado o resultado desta tabela.

Tabela 4.14 Módulo 7 Atualização de Versão - Pacote de Software: Controle de Ponto Eletrónico

Módulo 7 Atualização de Versão - Pacote de Software: Controle de Ponto Eletrônico

\begin{tabular}{|l|r|r|r|r|r|}
\hline Palavra Chave & \multicolumn{1}{|c|}{ Mínimo } & \multicolumn{1}{|c|}{ Máximo } & Média & Desvio Padrão \\
\hline M7-1 Implantação da nova versão & 1 & 6 & 6 & 6,00 & 0,00 \\
\hline M7-2 Necessidade de novas funções & 1 & 2 & 2 & 2,00 & 0,00 \\
\hline M7-3 Melhoria nas funções existentes & 1 & 1 & 1 & 1,00 & 0,00 \\
\hline M7-4 Substituição de funções & 1 & 7 & 7 & 7,00 & 0,00 \\
\hline M7-5 Mudanças de processos & 1 & 3 & 3 & 3,00 & 0,00 \\
\hline M7-6 Automatização de processos & 1 & 3 & 3 & 3,00 & 0,00 \\
\hline M7-7 Teste da nova versão & 1 & 6 & 6 & 6,00 & 0,00 \\
\hline
\end{tabular}

Módulo 7 Atualização de Versão do Pacote de Software - Pacote de Software: Controle de Ponto Eletrônico

Apenas uma pessoa que opera o pacote de software foi entrevistada nesse Modulo de Avaliação e respondeu o questionário. O entrevistado é da seção de Registro e Pagamento. Os pesos mais baixos estão próximos da pontuação ideal.

Implantação da nova versão e teste da nova versão receberam o peso 6 , ou seja, 0 entrevistado julga que o momento é adequado para implantação da nova versão e tem conhecimento que ela já foi implantada por outra empresa. Necessidade de novas funções recebeu o peso 2, ou seja, o usuário necessita de novas funções. Melhoria nas funções existentes recebeu o peso 1, ou seja, o entrevistado conhece a nova versāo que será implantada e está convicto que ela trará melhorias. Substituições de funções recebeu o peso 7, ou seja, a resposta para esta palavra chave foi não, pois o usuário tem o conhecimento que nenhuma função será eliminada, ou substituída pela outra. Mudanças de processo e automatização de processos recebeu o peso 3, ou seja, existiram 
poucas mudanças no ambiente empresarial e falta ainda a automatização de alguns processos para eliminação de redundância de dados e tempo do re-trabalho.

Comentário: A conclusão é que deve-se efetuar a atualização de versão do pacote de software.

Comentário sobre o pacote de software Controle de Ponto eletrônico: Quanto ao pacote de software controle de ponto eletrônico observa-se que o usuário possui o controle do pacote de software sabendo das limitações e dos benefícios que o pacote de software traz para o seu trabalho.

\section{Pacote de Software: Contabilidade i}

A Tabela 4.15 apresentada mostra o resultado da aplicação do Módulo de Avaliação da adequação do pacote de software ao ambiente empresarial sobre o pacote de software contabilidade i e a seguir será comentado o resultado desta tabela.

\section{Módulo 1 Adequação - Pacote de Software: Contabilidade i}

Três pessoas que operam o pacote de software foram entrevistadas nesse Modulo de Avaliação e todas responderam o questionário. Os três entrevistados são da seção de Contabilidade Geral. As palavras chaves estão agrupadas pela pontuação mínima e máxima. Os pesos mais baixos estão proximos da pontuação ideal com exceção das palavras chaves M1-7 Acesso ao software e M1-8 Outras pessoas utilizam sua área de trabalho que a pontuação mais alta é a ideal.

Satisfação do usuário, confiança receberam um peso variando de 3 até 5 . Isto mostra que os usuários não estão insatisfeitos com o pacote de software.

Completitude, interpretação dos dados receberam um peso variando de 1 até 3, ou seja, existem funções que o usuário deseja e não estão disponíveis no pacote de software e poucas são as mensagens fornecidas pelo sistema que ele consegue interpretar.

Fluxos de informações, processos recebeu um peso variando de 4 ate 5 , apesar do pacote de software ser parametrizado, os usuários entendem que ele não retrata a empresa. 
Importar dados, exportar dados, instalação do software receberam o peso 2, ou seja, os usuários não conseguem manipular os dados e instalar o pacote de software sem a ajuda do analista de sistemas.

Tabela 4.15 Módulo 1 Adequação - Pacote de Software: Contabilidade i

\begin{tabular}{|c|c|c|c|c|}
\hline \multicolumn{5}{|c|}{ Módulo 1 Adequação - Pacote de Software: Contabilidade i } \\
\hline Palavra Chave $N=3$ & Mínimo & Máximo & Média & Desvio Padrão \\
\hline M1-1 Satisfação do usuário & 3 & 5 & 4,33 & 1,15 \\
\hline M1-2 Completitude & 1 & 3 & 2,00 & 1,00 \\
\hline M1-3 Fluxos de informações, processos & 4 & 5 & 4,67 & 0,58 \\
\hline Ml-4 Exatidão dos dados & 5 & 5 & 5,00 & 0,00 \\
\hline M1-5 Importar dados & 2 & 2 & 2,00 & 0,00 \\
\hline M1-6 Exportar dados & 2 & 2 & 2,00 & 0,00 \\
\hline M1-7 Acesso ao sofiware & 5 & 5 & 5,00 & 0,00 \\
\hline M1-8 Outras pessoas utilizam sua área de trabalho & 5 & 5 & 5,00 & 0,00 \\
\hline M1-9 Confiança & 3 & 5 & 4,00 & 1,00 \\
\hline M1-10 Interpretaçāo dos dados & 1 & 3 & 2,00 & 1,00 \\
\hline M1-11 Abrangência do conhecimento & 3 & 4 & 3,33 & 0,58 \\
\hline M1-12 Outros softwares similares & 1 & 4 & 2,67 & 1,53 \\
\hline M1-13 Facilidade de utilizaçāo & 2 & 2 & 2,00 & 0,00 \\
\hline M1-14 Operaçāo do software & 2 & 3 & 2,67 & 0,58 \\
\hline M1-15 Tempo de processamento das funções & 2 & 3 & 2,67 & 0,58 \\
\hline M1-16 Velocidade do software & 2 & 4 & 3,00 & 1,00 \\
\hline M1-17 Tempo de impressão & 3 & 4 & 3,67 & 0,58 \\
\hline M1-18 Instalação do software & 2 & 2 & 2,00 & 0,00 \\
\hline
\end{tabular}

Exatidão dos dados, acesso ao software e outras pessoas utilizam sua área de trabalho receberam o peso 5, ou seja, os usuários não estão entrando com dados no sistema, e não divulgam a sua senha para ninguém e nem permitem outras pessoas acessarem o pacote de software.

Abrangência do conhecimento e tempo de impressão receberam um peso variando de 3 até 4, ou seja, as pessoas estão insatisfeitas com o tempo de impressão de seus relatórios e possuem pouco conhecimento do pacote de software que utilizam.

Outros softwares similares recebeu um peso variando de 1 ate 4 , ou seja, alguns dos entrevistados conhecem outros softwares similares.

Facilidade de utilização recebeu em consenso o peso 2, ou seja, o entrevistado considera o pacote de software fácil de utilizar. 
Operação do software e tempo de processamento das funções receberam um peso variando de 2 ate 3, ou seja, alguns entrevistados tem facilidade em operar o software enquanto outros conhecem pouco o software e sentem dificuldade na sua operação.

Velocidade do software recebeu um peso variando de 2 até 4 , ou seja, alguns usuários acham o sistema lento. Assim, essa palavra chave precisa ser analisada pelo pessoal técnico.

Comentários: Apesar do pacote de software estar instalado e implantado e ter ocorrido o treinamento e até visitas técnicas para o usuário conhecer o software funcionando em outras empresas, verifica-se que os usuários não estão alimentando, ou seja atualizando os dados do pacote de software.

\section{Módulo 2 Qualidade da Documentação - Pacote de Software: Contabilidade i}

Este módulo não foi aplicado porque os usuários não utilizam o manual do usuário. Uma sugestão é a leitura do manual do usuário pelos usuários que operam o pacote de software.

\section{Módulo 3 Serviços de Manutenção - Pacote de Software: Contabilidade i}

Este módulo não foi aplicado pois o serviço de manutenção é realizado através do analista de sistemas da empresa que é acionado e o mesmo entra em contato com a empresa fornecedora do pacote de software, caso necessite.

A Tabela 4.16 apresenta o resultado da aplicação do Módulo de Avaliação do treinamento do pacote de software sobre o pacote de software contabilidade i e a seguir será comentado o resultado desta tabela.

\section{Módulo 4 Treinamento Realizado- Pacote de Software: Contabilidade I}

Duas pessoas que operam o pacote de software foram entrevistadas nesse Modulo de Avaliaçāo e todas responderam o questionário. $O$ dois entrevistados são da seção de Contabilidade Geral. As palavras chaves estão agrupadas pela pontuação mínima e máxima. Os pesos mais baixos estão proximos da pontuação ideal com exceção das palavras chaves M4-13 Freqüência de falhas e M4-14 Gravidade da falha que a pontuação mais alta é a ideal. 
Completitude, clareza e oratória, exemplos receberam um peso variando de 1 até 2, ou seja, no treinamento foram apresentadas quase todas as funções, e o instrutor explanou com clareza possibilitando esclarecer o usuário de suas dúvidas com a utilização de exemplos adequados no contexto da empresa.

Tabela 4.16 Módulo 4 Treinamento - Pacote de Software: Contabilidade i

\begin{tabular}{|l|r|r|r|r|r|}
\hline Módulo 4 Treinamento - Pacote de Software: Contabilidade i \\
\hline Palavra Chave & $\mathbf{N}$ & Mínimo & \multicolumn{1}{l|}{ Máximo } & \multicolumn{1}{l|}{ Média } & Desvio Padrão \\
\hline M4-1 Completitude & 2 & 1 & 2 & 1,50 & 0,71 \\
\hline M4-2 Consistência & 2 & 1 & 1 & 1,00 & 0,00 \\
\hline M4-3 Cronograma & 2 & 2 & 4 & 3,00 & 1,41 \\
\hline M4-4 Satisfação com o treinamento & 2 & 2 & 3 & 2,50 & 0,71 \\
\hline M4-5 Exatidão das informações & 2 & 1 & 1 & 1,00 & 0,00 \\
\hline M4-6 Organização da apresentação & 2 & 1 & 1 & 1,00 & 0,00 \\
\hline M4-7 Apresentação visual & 2 & 6 & 7 & 6,50 & 0,71 \\
\hline M4-8 Clareza, oratória & 2 & 1 & 2 & 1,50 & 0,71 \\
\hline M4-9 Exemplos & 2 & 1 & 2 & 1,50 & 0,71 \\
\hline M4-10 Ilustrações & 2 & 5 & 8 & 6,50 & 2,12 \\
\hline M4-11 Conceitual e prática & 2 & 5 & 5 & 5,00 & 0,00 \\
\hline M4-12 Consultas adicionais bibliográficas & 2 & 7 & 7 & 7,00 & 0,00 \\
\hline M4-13 Frequência de falhas & 2 & 3 & 4 & 3,50 & 0,71 \\
\hline M4-14 Gravidade da falha ocorrida & 2 & 7 & 7 & 7,00 & 0,00 \\
\hline
\end{tabular}

Consistência, exatidão das informações, organização da apresentação receberam o peso 1 , ou seja, foram muito bem avaliadas do ponto de vista do entrevistado.

Cronograma recebeu um peso variando de 2 até 4, houve uma discordância do ponto de vista do entrevistado, pois um usuário acredita que deveria ter sido melhor planejado o tempo em relação ao conteúdo dado e o outro acredita que o tempo foi suficiente, entretanto verifica-se a necessidade de maior cuidado no planejamento do cronograma com um comprometimento do usuário em sua elaboração.

Satisfação com o treinamento recebeu um peso variando de 2 até 3 , ou seja, um usuário está satisfeito enquanto outro não está, precisando melhorar o treinamento para atingir a parte de o usuário que ficou insatisfeito.

Apresentaçāo visual recebeu um peso variando de 6 até 7 , ou seja, poderia ser melhorada com a utilização de mais recursos para que se torne mais agradável 
Ilustrações, conceitual e prática receberam um peso 5, ou seja, os entrevistados nāo ficaram satisfeitos com o parte conceitual e prática do treinamento e não foram utilizadas nenhum tipo de ilustraçōes.

Freqüência de falhas recebeu um peso variando de 3 até 4, ou seja, ocorreram várias falhas no pacote de software durante o treinamento.

Consultas adicionais bibliográficas, gravidade da falha ocorrida receberam um peso 7, ou seja, o instrutor do treinamento não indicou bibliografia referente as dúvidas dos usuários para complementação do assunto dado e apesar de ocorrer várias falhas, elas nāo afetaram o treinamento.

Comentários: Verifica-se de maneira geral uma insatisfação do usuário com o treinamento realizado.

\section{Módulo 5 Documentação de Treinamento - Pacote de Software: Contabilidade i}

Este módulo não foi aplicado porque o treinamento foi totalmente prático não se utilizando de documentação. A falta de uma documentação deixou o usuário desorientado prejudicando o seu aproveitamento.

A Tabela 4.17 apresentada abaixo mostra o resultado da aplicação do modulo de avaliação dos serviços técnicos prestados pela empresa fornecedora sobre o pacote de software contabilidade $\mathrm{i}$ e a seguir será comentado o resultado desta tabela.

Tabela 4.17 Módulo 6 Serviços Técnicos - Pacote de Software: Contabilidade i

\begin{tabular}{|l|r|r|r|r|r|}
\hline Módulo 6 Serviços Técnicos - Pacote de Software: Contabilidade i \\
\hline Palavra Chave & N & Mínimo & Máximo & Média & \multicolumn{1}{c|}{ Desvio Padrão } \\
\hline M6-1 Atendimento pelo fornecedor & 1 & 4 & 4 & 4,00 & 0,00 \\
\hline M6-2 Contato telefônico & 1 & 8 & 8 & 8,00 & 0,00 \\
\hline M6-3 Tempo hábil para soluçāo do problema & 1 & 4 & 4 & 4,00 & 0,00 \\
\hline
\end{tabular}

\section{Módulo 6 Serviços Técnicos Prestados - Pacote de Software: Contabilidade i}

Apenas uma pessoa que opera o pacote de software foi entrevistada nesse Modulo de Avaliação e respondeu o questionário. O entrevistado é da seção de Contabilidade Geral. 
Atendimento pelo fornecedor, tempo hábil para a soluçāo do problema receberam o peso 4. O contato telefônico é realizado pelo analista de sistemas que contacta os serviços técnicos. Verifica-se que o usuário está insatisfeito com os serviços prestados pela empresa fornecedora do software.

Módulo 7 Atualização de Versão do Pacote de Software - Pacote de Software: Contabilidade i

Este módulo não foi aplicado pois o usuário que opera o pacote de software não possui conhecimento para responde-lo.

Comentários sobre o pacote de software contabilidade i: Observa-se uma insatisfação do usuário com o pacole de software contabilidade i tendo como consequiência a não utilização deste. Precisa-se de um estudo na área de contabilidade para verificar a viabilidade deste pacote de software, pois ele acarreta custos de manutenção e de prestação de serviços para a empresa devido o contrato firmado com a empresa fornecedora do pacote de software.

\section{Pacote de Software: Contabilidade ii}

A Tabela 4.18 apresentada mostra o resultado da aplicação do modulo de avaliação da adequação do pacote de software no ambiente empresarial sobre o pacote de software contabilidade ii e a seguir será comentado o resultado desta tabela.

\section{Módulo 1 Adequação - Pacote de Software: Contabilidade ii}

Duas pessoas que operam o pacote de software foram entrevistadas nesse Modulo de Avaliação e todas responderam o questionário. Os dois entrevistados sāo da seção Contabilidade Geral. As palavras chaves estão agrupadas pela pontuação mínima e máxima. Os pesos mais baixos estão proximos da pontuação ideal com exceção das palavras chaves $M I-7$ Acesso ao software e M1-8 Outras pessoas utilizam sua área de trabalho que a pontuação mais alta é a ideal.

Satisfação do usuário, exatidão dos dados, interpretaçāo dos dados, facilidade de utilização, abrangência do conhecimento receberam um peso variando de 1 até 2 , ou seja, os usuários, em geral, estão satisfeitos com o pacote de software sabendo interpretar as mensagens 
fornecidas pelo sistema e consideram o pacote de software fácil de utilizar e conhecem quase todo o pacote.

Tabela 4.18 Módulo 1 Adequação - Pacote de Software: Contabilidade ii

\begin{tabular}{|c|c|c|c|c|}
\hline \multicolumn{5}{|c|}{ Módulo 1 Adequação - Pacote de Software: Contabilidade ii } \\
\hline $\begin{array}{ll}\text { Palavra Chave } & \mathrm{N}=2 \\
\end{array}$ & Mínimo & Máximo & Média & Desvio Padrão \\
\hline Ml-1 Satisfação do usuário & 1 & 2 & 2,50 & 0,71 \\
\hline Ml-2 Completitude & 1 & 1 & 1,00 & 0,00 \\
\hline M1-3 Fluxos de informações, processos & 2 & 2 & 2,00 & 0,00 \\
\hline Ml-4 Exatidão dos dados & 1 & 2 & 1,50 & 0,71 \\
\hline M1-5 Importar dados & 1 & 2 & 1,50 & 0,71 \\
\hline Ml-6 Exportar dados & 1 & 1 & 1,00 & 0,00 \\
\hline M1-7 Acesso ao software & 5 & 5 & 5,00 & 0,00 \\
\hline M1-8 Outras pessoas utilizam sua área de trahalho & 5 & 5 & 5,00 & 0.00 \\
\hline Ml-9 Confiança & 1 & 1 & 1,00 & 0,00 \\
\hline M1-10 Interpretação dos dados & 1 & 2 & 1,50 & 0,71 \\
\hline M1-11 Abrangência do conhecimento & 1 & 2 & 1,50 & 0,71 \\
\hline M1-12 Outros softwares similares & 3 & 4 & 3,50 & 0,71 \\
\hline M1-13 Facilidade de utilização & 1 & 2 & 1,50 & 0,71 \\
\hline M1-14 Operação do software & 2 & 2 & 2,00 & 0,00 \\
\hline M1-15 Tempo de processamento das funções & 2 & 3 & 2,50 & 0,71 \\
\hline M1-16 Velocidade do soft ware & 2 & 3 & 2,50 & 0,71 \\
\hline M1-17 Tempo de impressão & 2 & 3 & 2,50 & 0,71 \\
\hline M1-18 Instalaçāo do software & 2 & 2 & 2,00 & 0,00 \\
\hline
\end{tabular}

Completitude, confiança receberam em consenso o peso 1 , ou seja, todas as funções que o usuário deseja estão implementadas no pacote de software e além disso, ele confia cem por cento no software, pois até agora não apresentou falha.

Fluxos de informações e processos, operação do software em consenso receberam o peso 2, ou seja, o pacote de software está bem próximo da realidade da empresa e o usuário tem facilidade de utilizar o software.

Importar dados recebeu um peso variando de 1 ate 2 , ou seja, um usuário consegue importar dados de outros sistema para o pacote de software enquanto o outro não sabe.

Exportar dados recebeu em consenso o peso 1, ou seja, os usuários exportam dados para outros sistemas. 
Acesso ao software, outras pessoas utilizam sua área de trabalho receberam em consenso o peso 5 , ou seja o usuário não divulgou sua senha para ninguém e nem permite que outras pessoas utilizem sua área de trabalho.

Outros softwares similares recebeu um peso variando de 3 ate 4 , ou seja, as pessoas possuem conhecimento de outros pacotes de software.

Tempo de processamento das funções, tempo de impressão, velocidade do software receberam um peso variando de 2 ate 3 , ou seja, estas palavras chaves atendem os expectativas dos usuários.

Instalação do software recebeu o peso 2, ou seja, o entrevistado não possui conhecimentos técnicos para efetuar esta tarefa.

Comentário: observa-se que este pacote de software foi bem avaliado por seus operadores.

A seguir a Tabela 4.19 apresentada abaixo mostra o resultado da aplicação do modulo de avaliação da qualidade da documentação sobre o pacote de software contabilidade ii e a seguir será comentado o resultado desta tabela.

\section{Módulo 2 Qualidade da Documentação - Pacote de Software: Contabilidade ii}

Uma pessoa que opera o pacote de software foi entrevistada nesse M6dulo de Avaliação e respondeu o questionário menos a palavra chave $M 2-12$ Referências cruzadas. O entrevistado é da seção de Contabilidade Geral. Os pesos mais baixos estāo proximos da pontuação ideal.

Completitude, consistência, exatidão, organização receberam o peso 1, ou seja, foi avaliada pelo usuário com nota máxima.

Fácil localização, Interface, glossário, manual de instalaçāo do software, requisitos de hardware, instalação receberam o peso 1 , ou seja, a documentação possui índices que ajuda a orientação do usuário e faz referências a interfaces com outros softwares e possui um glossário dos termos técnicos utilizados, apresentando requisitos de hardware e também faz referências de instalaçāo do pacote de software. 
Apresentação visual, clareza, exemplos, manuseio receberam o peso 2, ou seja, o usuário julga a documentação do pacote de software agradável, apresentando um texto claro e possuindo exemplos que possibilitam o esclarecimento de dúvidas e também considera o tamanho e peso do manual do usuário bom.

Tabela 4.19 Módulo 2 Documentação - Pacote de Software: Contabilidade ii

\begin{tabular}{|l|r|r|r|r|r|}
\hline Módulo 2 Documentação - Pacote de Software: Contabllidade ii \\
\hline Palavra Chave & N & \multicolumn{1}{c|}{ Mínimo } & \multicolumn{1}{c|}{ Máximo } & Média & Desvio Padrão \\
\hline M2-1 Completitude & 1 & 1 & 1 & 1,00 & 0,00 \\
\hline M2-2 Consistência & 1 & 1 & 1 & 1,00 & 0,00 \\
\hline M2-3 Exatidão & 1 & 1 & 1 & 1,00 & 0,00 \\
\hline M2-4 Interface & 1 & 6 & 6 & 6,00 & 0,00 \\
\hline M2-5 Organização & 1 & 1 & 1 & 1,00 & 0,00 \\
\hline M2-6 Apresentação visual & 1 & 2 & 2 & 2,00 & 0,00 \\
\hline M2-7 Clareza & 1 & 2 & 2 & 2,00 & 0,00 \\
\hline M2-8 Exemplos & 1 & 2 & 2 & 2,00 & 0,00 \\
\hline M2-9 Ilustrações & 1 & 5 & 5 & 5,00 & 0,00 \\
\hline M2-10 Fácil localização & 1 & 1 & 1 & 1,00 & 0,00 \\
\hline M2-11 Glossário & 1 & 1 & 1 & 1,00 & 0,00 \\
\hline M2-12 Referências cruzadas & 0 & 0 & 0 & 0,00 & 0,00 \\
\hline M2-13 Consultas adicionais de bibliografia & 1 & 2 & 2 & 2,00 & 0,00 \\
\hline M2-14 Manuseio & 1 & 2 & 2 & 2,00 & 0,00 \\
\hline M2-15 Manual de instalação do software & 1 & 1 & 1 & 1,00 & 0,00 \\
\hline M2-16 Requisitos de hardware & 1 & 1 & 1 & 1,00 & 0,00 \\
\hline M2-17 Instalação & 1 & 1 & 1 & 1,00 & 0,00 \\
\hline
\end{tabular}

Consultas adicionais de bibliografia recebeu o peso 2, ou seja, a documentação não apresentou consultas adicionais de bibliografia.

Ilustrações recebeu o peso 5 , ou seja, a documentação não apresentou nenhum tipo de ilustração.

O usuário não soube responder sobre a palavra chave referências cruzadas.

Comentário: Observa-se que os usuários atribuíram uma boa qualidade para o manual do usuário. 
Módulo 3 Serviços de Manutenção - Pacote de Software: Contabilidade ii

Este módulo não foi aplicado pois o pacote de software foi implantado há pouco tempo, não conseguindo o usuário respondê-lo.

A Tabela 4.20 mostra o resultado da aplicação do modulo de avaliação do treinamento realizado sobre o pacote de software contabilidade ii e a seguir será comentado o resultado desta tabela.

Tabela 4.20 Módulo 4 Treinamento - Pacote de Software: Contabilidade ii

\begin{tabular}{|l|r|r|r|r|r|}
\hline Módulo 4 Treinamento - Pacote de Software: Contabilidade ii \\
\hline Palavra Chave & N & Mínimo & Máximo & Média & Desvio Padrão \\
\hline M4-1 Completitude & 3 & 1 & 2 & 1,33 & 0,58 \\
\hline M4-2 Consistência & 3 & 1 & 2 & 1,33 & 0,58 \\
\hline M4-3 Cronograma & 3 & 2 & 4 & 3,00 & 1,00 \\
\hline M4-4 Satisfação com o treinamento & 3 & 2 & 2 & 2,00 & 0,00 \\
\hline M4-5 Exatidão das informações & 3 & 1 & 2 & 1,33 & 0,58 \\
\hline M4-6 Organização da apresentação & 3 & 2 & 3 & 2,67 & 0,58 \\
\hline M4-7 Apresentação visual & 3 & 1 & 7 & 4,67 & 3,21 \\
\hline M4-8 Clareza, oratória & 3 & 1 & 2 & 1,67 & 0,58 \\
\hline M4-9 Exemplos & 3 & 1 & 2 & 1,33 & 0,58 \\
\hline M4-10 Ilustrações & 3 & 5 & 8 & 6,00 & 1,73 \\
\hline M4-11 Conceitual e prática & 3 & 1 & 2 & 1,67 & 0,58 \\
\hline M4-12 Consultas adicionais bibliograficas & 3 & 7 & 7 & 7,00 & 0,00 \\
\hline M4-13 Freqüência de falhas & 3 & 4 & 5 & 4,67 & 0,58 \\
\hline M4-14 Gravidade da falha ocorrida & 3 & 6 & 8 & 7,33 & 1,15 \\
\hline
\end{tabular}

\section{Módulo 4 Treinamento Realizado - Contabilidade ii}

Três pessoas que operam o pacote de software foram entrevistadas nesse Módulo de Avaliação e todas responderam o questionário. O três entrevistados são da seção de Contabilidade Geral. As palavras chaves estão agrupadas pela pontuação mínima e máxima. Os pesos mais baixos estão proximos da pontuação ideal com exceção das palavras chaves M4-13 Freqüência de falhas e M4-14 Gravidade da falha que a pontuação mais alta é a ideal.

Completitude, consistência, exatidão das informações, clareza e oratória exemplos, conceitual e prática receberam um peso variando de 1 até 2 , recebeu uma boa pontuação pelos entrevistados. 
Cronograma obteve um peso variando de 2 até 4 , mostrando que precisa ser melhor planejado.

Satisfação com o treinamento recebeu em consenso o peso 2, ou seja, todos ficaram satisfeitos com o treinamento.

Organização da apresentação recebeu um peso variando de 2 até 3 , ou seja, o instrutor precisa melhorar a sua apresentação para satisfazer a maioria dos usuários.

$\mathrm{O}$ treinamento não possuiu ilustrações recebendo um peso 5 e também não apresentou consultas adicionais de bibliografia recebendo o peso 7.

Freqüência de falhas recebeu um peso variando de 4 ate 5. Isto significa que o treinamento ocorreu quase sem falhas e a gravidade da falha ocorrida que recebeu o peso 5, ou seja, não afetou o treinamento realizado.

Comentários: Apesar de todos os usuários ficarem satisfeitos com o treinamento alguns aspectos como cronograma, ilustração e consultas adicionais de bibliografia teriam que ser revistos para a melhora na qualidade de um novo treinamento.

Módulo 5 Documentação do Treinamento - Pacote de Software: Contabilidade ii

O treinamento foi totalmente prático, sem a apresentação de qualquer tipo de documentação de apresentação pelo instrutor, por exemplo: manual, apostilha, folheto.

A seguir a Tabela 4.21 mostra o resultado da aplicação do módulo de avaliação dos serviços técnicos prestados sobre o pacote de software contabilidade ii e a seguir será comentado o resultado desta tabela

Tabela 4.21 Módulo 6 Serviços Técnicos - Pacote de Software: Contabilidade ii

\begin{tabular}{|l|r|r|r|r|r|}
\hline Módulo 6 Serviços Técnicos - Pacote de Software: Contabilidade ii \\
\hline Palavra Chave & N & Mínimo & Máximo & Média & Desvio Padrão \\
\hline M6-1 Atendimento pelo fornecedor & 2 & 3 & 3 & 3,00 & 0,00 \\
\hline M6-2 Contato telefônico & 2 & 2 & 3 & 2,50 & 0,71 \\
\hline M6-3 Tempo hábil para solução do problema & 2 & 3 & 3 & 3,00 & 0,00 \\
\hline
\end{tabular}




\section{Módulo 6 Serviços Técnicos Prestados - Pacote de Software: Contabilidade ii}

Duas pessoas que operam o pacote de software foram entrevistadas nesse Modulo de Avaliaçāo e responderam o questionário. Os entrevistados são da seção de Contabilidade Geral.

Atendimento pelo fornecedor recebeu em consenso o peso 3, os entrevistados julgam que a empresa fornecedora possui um bom atendimento a seus clientes. Contato telefônico recebeu um peso variando de 2 ate 3 , os entrevistados estão contentes com o atendimento pelo telefone por parte do fornecedor do pacote de software. Tempo hábil para soluçāo do problema recebeu em consenso um peso 3, ou seja, o fornecedor resolveu o problema do usuário dentro do prazo para ele realizar sua atividades.

Comentário: Observa-se que os usuários estão satisfeitos com a qualidade dos serviços técnicos prestados.

A Tabela 4.22 apresenta o resultado da aplicaçāo do Modulo de Avaliação da atualização de versão sobre o pacote de software contabilidade ii e a seguir o resultado será comentado.

Tabela 4.22 Módulo 7 Atualização de Versão - Pacote de Software: Contabilidade ii

\begin{tabular}{|l|r|r|r|r|r|}
\hline Módulo 7 Atualização de Versão - Pacote de Software: Contabilidade ii \\
\hline Palavra Chave & \multicolumn{1}{|c|}{ M } & \multicolumn{1}{c|}{ Mínimo } & \multicolumn{1}{l|}{ Máximo } & \multicolumn{1}{l|}{ Média } & \multicolumn{1}{l|}{ Desvio Padrão } \\
\hline M7-1 Implantação da nova versão & 2 & 6 & 7 & 6,50 & 0,71 \\
\hline M7-2 Necessidade de novas funções & 2 & 1 & 2 & 1,50 & 0,71 \\
\hline M7-3 Melhoria nas funções existentes & 2 & 1 & 2 & 1,50 & 0,71 \\
\hline M7-4 Substituição de funções & 2 & 6 & 7 & 6,50 & 0,71 \\
\hline M7-5 Mudanças de processos & 2 & 1 & 2 & 1,50 & 0,71 \\
\hline M7-6 Automatização de processos & 2 & 2 & 3 & 2,50 & 0,71 \\
\hline M7-7 Teste da nova versão & 2 & 6 & 6 & 6,00 & 0,00 \\
\hline
\end{tabular}

\section{Módulo 7 Atualização de Versão - Pacote de Software: Contabilidade ii}

Duas pessoas que operam o pacote de software foram entrevistadas nesse M6dulo de Avaliação e responderam o questionário. Os entrevistados são da seção de Contabildade Geral. Os pesos mais baixos estão próximos da pontuação ideal.

Implantação da nova versão, substituições de funções receberam um peso variando de 6 até 7, ou seja, um entrevistado considerou que o momento é adequado para realizar a atualização do 
pacote de software enquanto o outro considerou que nāo é; e algumas funções serão substituídas na nova versão.

Necessidade de novas funções, melhoria nas funções existentes, mudanças de processo receberam um peso variando de 1 atê 2 , essas palavras chaves foram bem pontuadas, ou seja, ocorreram mudanças na organização que exigirão melhoria nas funçōes existentes e criação de outras para atender as necessidades do usuário.

Automatização de processos recebeu um peso variando de 2 até 3, ou seja, falta a automatização de alguns processos dentro da empresa, assim nota-se a necessidade de um estudo e planejamento para essa atividade.

Teste da nova versão recebeu um peso 6 , ou seja, a nova versão já foi implantada por outra empresa.

Comentário: Observa-se que existe a necessidade de atualizar a versão do pacote de software, mas os usuários terão que entrar em acordo sobre o melhor momento.

Comentário sobre o pacote de software contabilidade ii: $O$ pacote de software contabilidade ii possui qualidade segundo a avaliação dada pelo usuário apesar de ter sido implantado a pouco tempo, menos de dois meses e quase não ter sido utilizado.

\section{Pacote de Software: Controle de Materiais}

A Tabela 4.23 mostra o resultado da aplicação do Módulo de Avaliação da adequação do pacote de software ao ambiente empresarial sobre o pacote de software controle de materiais e a seguir o resultado será comentado.

\section{Módulo 1 Adequação ao Ambiente Empresarial - Pacote de Software: Controle de Materiais}

Quatro pessoas que operam o pacote de software foram entrevistadas nesse M6dulo de Avaliação e todas responderam o questionário. Os quatro entrevistados são da seção de Controle de de estoque e Catalogação. As palavras chaves estão agrupadas pela pontuação mínima e máxima. Os pesos mais baixos estão próximos da pontuação ideal com exceção das palavras chaves $M 1-7$ 
Acesso ao software e M1-8 Outras pessoas utilizam sua área de trabalho que a pontuação mais alta é a ideal.

Tabela 4.23 Módulo 1 Adequação - Pacote de Software: Controle de Materiais

\begin{tabular}{|c|c|c|c|c|}
\hline \multicolumn{5}{|c|}{ Módulo 1 Adequação - Pacote de Software: Controle de Materiais } \\
\hline Palavra Chave $\quad N=4$ & Mínimo & Máximo & Média & Desvio Padrão \\
\hline M1-1 Satisfação do usuário & 3 & 5 & 3,50 & 1,00 \\
\hline M1-2 Completitude & 2 & 4 & 2,50 & 1,00 \\
\hline M1-3 Fluxos de informações, processos & 2 & 4 & 2,75 & 0,96 \\
\hline M1-4 Exatidão dos dados & 1 & 2 & 1,50 & 0,58 \\
\hline M1-5 Importar dados & 2 & 2 & 2,00 & 0,00 \\
\hline M1-6 Exportar dados & 2 & 2 & 2,00 & 0,00 \\
\hline M1-7 Acesso ao software & 4 & 5 & 4,75 & 0,50 \\
\hline M1-8 Outras pessoas utilizam sua área de trabalho & 3 & 5 & 4,50 & 1,00 \\
\hline M1-9 Confiança & 2 & 2 & 2,00 & 0,00 \\
\hline M1-10 Interpretação dos dados & 2 & 2 & 2,00 & 0,00 \\
\hline M1-11 Abrangência do conhecimento & 2 & 3 & 2,50 & 0,58 \\
\hline M1-12 Outros softwares similares & 2 & 5 & 3,75 & 1,50 \\
\hline M1-13 Facilidade de utilização & 2 & 4 & 3,00 & 0,82 \\
\hline M1-14 Operação do software & 2 & 2 & 2,00 & 0,00 \\
\hline M1-15 Tempo de processamento das funções & 3 & 5 & 4,00 & 1,15 \\
\hline M1-16 Velocidade do software & 3 & 5 & 3,75 & 0,96 \\
\hline M1-17 Tempo de impressão & 1 & 4 & 2,75 & 1,26 \\
\hline M1-18 Instalação do software & 2 & 2 & 2,00 & 0,00 \\
\hline
\end{tabular}

Satisfação do usuário, outras pessoas utilizam sua área de trabalho, tempo de processamento das funções, velocidade do software receberam um peso variando de 3 até 5 , essas palavras chaves necessitam de melhora para uma maior satisfação do usuário.

Completitude, fluxos de informações e processos, facilidade de utilizaçāo receberam um peso variando de 2 até 4, ou seja, ocorreu uma discordância de opiniões entre os usuários do pacote de software necessitando de um estudo para verificar a melhora nesses aspectos.

Exatidão dos dados recebeu um peso variando de 1 até 2, ou seja, os dados existentes estão corretos e estão sempre sendo atualizados.

Importar dados, exportar dados, instalação do software receberam o peso 2 , ou seja, o usuário não consegue realizar essas atividades sem a intervenção do analista de sistemas. 
Confiança, interpretação dos dados, operação do software receberam em consenso o peso 2 , recebeu uma boa pontuação, mostrando que o usuário entende que o pacote de software possui maturidade, e o usuário consegue e interpretar a maioria das mensagens fornecidas e a operar quase todo o software.

Abrangência de conhecimento recebeu um peso variando de 2 até 3 , ou seja, o usuário conhece pouco o pacote de software que opera.

Acesso ao software receberam um peso variando de 4 ate 5 , ou seja, o usuário divulgou a sua senha para outra pessoa e ela pode entrar no sistema e realizar modificações e depois não conseguir a identificação de quem realizou as alteraçōes.

Outros softwares similares receberam um peso variando de 2 ate 5 . Isto mostra que os usuários conhecem outros pacotes de software similares.

Facilidade de utilização recebeu um peso variando de 2 ate 4 . Isto mostra que no conceito do usuário o pacote de software não é tão fácil de utilizar.

Tempo de impressão recebeu um peso variando de 1 até 4, ou seja, necessita melhorar o tempo de impressão dos relatórios dos usuários.

Comentário: Observa-se que usuário julga que o pacote de software não está dequado ao ambiente empresarial necessitando de uma melhora na qualidade de várias características .

A Tabela 4.24 apresenta o resultado da aplicação do Modulo de Avaliação da qualidade da documentação do pacote de software no ambiente empresarial sobre o pacote de software controle de materiais e a seguir o resultado será comentado.

\section{Módulo 2 Qualidade da Documentação - Pacote de Software: Controle de Materiais}

Três pessoas que operam o pacote de software foram entrevistadas nesse Modulo de Avaliação e todas responderam o questionário. Os três entrevistados são da seção de Controle de Estoque e Catalogação. As palavras chaves estão agrupadas pela pontuação mínima e máxima. Os pesos mais baixos estão próximos da pontuação ideal. 
Completitude, exatidão houve um consenso e receberam o peso 2 , ou seja, estas palavras chaves foram bem avaliadas.

Glossário, referências cruzadas, consultas adicionais de bibliografia, manual de instalação do software, requisitos de hardware e instalação receberam o peso 2 , ou seja, a documentação não apresenta essas palavras chaves.

Tabela 4.24 Módulo 2 Documentação - Pacote de Software: Controle de Materiais

\begin{tabular}{|c|c|c|c|c|}
\hline Palavra Chave & \begin{tabular}{|l|} 
Mínimo \\
\end{tabular} & $\begin{array}{l}\text { Máximo } \\
\end{array}$ & Média & Desvio Padrão \\
\hline M2-1 Completitude & 2 & 2 & 2,00 & 0,00 \\
\hline M2-2 Consistência & 2 & $\overline{4}$ & 3,33 & 1,15 \\
\hline M2-3 Exatidão & 2 & 2 & 2,00 & 0,00 \\
\hline M2-4 Interface & 6 & 7 & 6,33 & 0,58 \\
\hline M2-5 Organização & 1 & 2 & 1,67 & 0,58 \\
\hline M2-6 Apresentação visual & 2 & 5 & 3,33 & 1,53 \\
\hline M2-7 Clareza & 3 & 3 & 3,00 & 0,00 \\
\hline M2.8 Exemplos & 3 & 4 & 3,33 & 0,58 \\
\hline M2-9 Ilustrações & 2 & 4 & 2,67 & 1,15 \\
\hline M2-10 Fácil localização & 1 & 2 & 1,67 & 0,58 \\
\hline M2-11 Glossário & 2 & 2 & 2,00 & 0,00 \\
\hline M2-12 Referências cruzadas & 2 & 2 & 2,00 & 0,00 \\
\hline M2-13 Consultas adicionais de bibliografia & 2 & 2 & 2,00 & 0,00 \\
\hline M2-14 Manuseio & 4 & 5 & 4,33 & 0,58 \\
\hline M2-15 Manual de instalação do software & 2 & 2 & 2,00 & 0,00 \\
\hline M2-16 Requisitos de hardware & 2 & 2 & 2,00 & 0,00 \\
\hline M2-17 Instalação & 2 & 2 & 2,00 & 0,00 \\
\hline
\end{tabular}

Consistência e ilustrações receberam um peso variando de 2 até 4 . Isto significa que houve divergências de opiniões necessitando de melhora nessas palavras chaves. Portanto para um usuário necessita adicionar ilustrações na documentação e que as informaçōes da documentação não estão de acordo com as funções que o software executa e com termos possuindo um único significado.

Interface recebeu um peso variando de 6 até 7, um usuário verificou que no manual existe referência a interfaces com outros softwares enquanto o outro usuário julgou que o manual não faz referência a interface com outros software.

Organização recebeu um peso variando de 1 até 2 , ou seja, os usuário considera que a documentação encontra-se organizada. 
Apresentação visual recebeu um peso variando de 2 até 5 , ou seja, ocorreu uma divergência de opiniões entre os usuários precisando ser melhorada essa palavra chave para que atenda a um dos usuários.

Clareza recebeu em consenso o peso 3 , ou seja, os usuários julgam que a redação da documentação é pouca clara dificultando o seu entendimento.

Exemplos recebeu um peso variando de 3 até 4, ou seja, a documentação deveria apresentar mais exemplos para facilitar o entendimento do usuário.

Fácil localizaçào recebeu um peso variando de 1 até 2, ou seja, alguns usuários julga que a documentação não tem índices.

Manuseio recebeu um peso variando de 4 até 5, ou seja, os usuários estão insatisfeitos com a forma da documentação principalmente no aspecto tamanho e peso do manual.

Comentário: Pode-se notar a insatisfação do usuário evidenciando que a documentação necessita de melhora em sua qualidade.

A Tabela 4.25 apresenta o resultado da aplicação do Modulo de Avaliação dos serviços de manutenção prestados sobre o pacote de software controle de materiais e a seguir o resultado será comentado.

Tabela 4.25 Módulo 3 Serviços de Manutenção - Pacote de Software: Controle de Materiais

\begin{tabular}{|l|r|r|r|r|r|r|}
\hline Módulo 3 Serviços de Manutenção - Pacote de Software: Controle de Materiais \\
\hline Palavra Chave & $\mathbf{N}$ & Mínimo & \multicolumn{1}{l|}{ Máximo } & \multicolumn{1}{l|}{ Média } & \multicolumn{1}{c|}{ Desvio Padrão } \\
\hline M3-1 Atualização da documentação & 1 & 2 & 2 & 2,00 & 0,00 \\
\hline $\begin{array}{l}\text { M3-2 Atualização do software em tempo } \\
\text { hábil para solução do problema }\end{array}$ & 1 & 4 & 4 & 4,00 & 0,00 \\
\hline M3-3 Novas versões & & & & & 1,00 & 0,00 \\
\hline
\end{tabular}

\section{Módulo 3 Serviços de Manutenção - Pacote de Software: Controle de Materiais}

Apenas uma pessoa que opera o pacote de software foi entrevistada nesse Modulo de Avaliação e respondeu o questionário. $O$ entrevistado é da seção de Controle de Estoque e Catalogação. Os pesos mais baixos estão próximos da pontuação ideal. 
O usuário não recebeu até o momento nenhuma atualização da documentação, pois recebeu o peso de 2. A Atualização do software em tempo hábil para solução do problema recebeu o peso 4, ou seja, ocorreu fora do prazo previsto. A palavra chave novas versões recebeu o peso 1 , mostrando que a empresa fornecedora do pacote de software disponibiliza as novas versões do pacote de software.

Comentários: Apesar da disponibilização das novas versões do pacote de software pela empresa fornecedora, ela não está atendendo os problemas que surgem com o pacote de software em tempo hábil e nem atualizando a documentação do usuário.

A Tabela 4.26 apresenta o resultado da aplicação do Módulo de Avaliação do treinamento realizado sobre o pacote de software controle de materiais e a seguir o resultado será comentado.

Tabela 4.26 Módulo 4 Treinamento - Pacote de Software: Controle de Materiais

\begin{tabular}{|l|r|r|r|r|r|}
\hline Módulo 4 Treinamento - Pacote de Software: Controle de Materiais \\
\hline Palavra Chave & N & \multicolumn{1}{|c|}{ Mínimo } & Máximo & Média & Desvio Padrão \\
\hline M4-1 Completitude & 2 & 1 & 3 & 2,00 & 1,41 \\
\hline M4-2 Consistência & 2 & 2 & 3 & 2,50 & 0,71 \\
\hline M4-3 Cronograma & 2 & 3 & 4 & 3,50 & 0,71 \\
\hline M4-4 Satisfação com o treinamento & 2 & 3 & 4 & 3,50 & 0,71 \\
\hline M4-5 Exatidão das informaçōes & 2 & 2 & 2 & 2,00 & 0,00 \\
\hline M4-6 Organização da apresentação & 2 & 2 & 3 & 2,50 & 0,71 \\
\hline M4-7 Apresentação visual & 2 & 6 & 6 & 6,00 & 0,00 \\
\hline M7-8 Clareza, oratória & 2 & 2 & 3 & 2,50 & 0,71 \\
\hline M7-9 Exemplos & 2 & 2 & 4 & 3,00 & 1,41 \\
\hline M4-10 Ilustrações & 2 & 2 & 2 & 2,00 & 0,00 \\
\hline M4-11 Conceitual e prática & 2 & 2 & 3 & 2,50 & 0,71 \\
\hline M4-12 Consultas adicionais bibliográficas & 2 & 7 & 7 & 7,00 & 0,00 \\
\hline M4-13 Frequiência de falhas & 2 & 1 & 5 & 3,00 & 2,83 \\
\hline M4-14 Gravidade da falha ocorrida & 1 & 6 & 8 & 7,00 & 1,41 \\
\hline
\end{tabular}

\section{Módulo 4 Treinamento Realizado - Pacote de Software: Controle de Materiais}

Duas pessoas que operam o pacote de software foram entrevistadas nesse Modulo de Avaliação e responderam o questionário com exceção da palavra chave M4-14 Gravidade da falha ocorrida respondida por um usuário. Os dois são da seção de Controle de Estoque e Catalogação. As palavras chaves estão agrupadas pela pontuação mínima e máxima. Os pesos mais baixos estão 
próximos da pontuaçāo ideal com exceção das palavras chaves M4-13 Freqüência de falhas e M414 Gravidade da falha que a pontuação mais alta é a ideal.

Completitude recebeu um peso variando de 1 até 3 , ou seja, no julgamento de um usuário não foram apresentadas todas as funções no treinamento.

Consistência, organização da apresentação, clareza e oratória, conceitual e prática receberam peso variando de 2 até 3, ou seja, essas palavras chaves atendem apenas a um dos usuários entrevistados. Cronograma, satisfação com o treinamento receberam um peso variando de 3 até 4, ou seja, os dois usuários estão insatisfeitos com essas palavras chaves.

Exatidão das informações, ilustrações receberam o peso 2, ou seja, foram bem pontuadas.

Apresentação visual, gravidade da falha ocorrida receberam o peso 6. Portanto a apresentação visual é agradável e as falhas ocorridas não afetaram o treinamento.

Exemplos recebeu um peso variando de 2 até 4. Isto significa que ocorreu discordância entre opiniões do usuário precisando o treinamento de possuir mais exemplos para que melhore o entendimento e esclareça as dúvidas de um dos usuários.

$\mathrm{O}$ instrutor não indicou no treinamento consultas adicionais de bibliografia, pois recebeu o peso 7.

Freqüência de falhas recebeu um peso variando de 1 ate 5 . Isto significa que ocorreram várias falhas no pacote de software durante o treinamento e enquanto outro usuário observou que não ocorreram falhas no treinamento. Essa divergência de conceitos é porque eles participaram de módulos de treinamento diferentes.

Comentários: Tentar para um dos usuários sanar a não aproveitamento do treinamento.

A Tabela 4.27 apresenta o resultado da aplicação do Módulo de Avaliaçāo da qualidade da documentação do treinamento realizado sobre o pacote de software controle de materiais e a seguir o resultado será comentado. 
Módulo 5 Documentação do Treinamento - Pacote de Software: Controle de Materiais

Duas pessoas que operam o pacote de software foram entrevistadas nesse Módulo de Avaliação e responderam o questionário. Os dois são da seção de Controle de Estoque e Catalogaçāo. As palavras chaves estão agrupadas pela pontuação mínima e máxima. Os pesos mais baixos estão próximos da pontuação ideal.

Tabela 4.27 Módulo 5 Documentação de Treinamento - Pacote de Software: Controle de Materiais

\begin{tabular}{|l|r|r|r|r|r|}
\hline Módulo 5 Documentação do Treinamento - Pacote de Software: Controle de Materiais \\
\hline Palavra Chave & N & Mínimo & \multicolumn{1}{|c|}{ Máximo } & \multicolumn{1}{c|}{ Média } & Desvio Padrão \\
\hline M5-1 Índices & 2 & 7 & 7 & 7 & 0,00 \\
\hline M5-2 Glossário & 2 & 7 & 7 & 7 & 0,00 \\
\hline M5-3 Referências cruzadas & 2 & 7 & 7 & 7 & 0,00 \\
\hline M5-4 Consultas adicionais bibliográficas & 2 & 7 & 7 & 7 & 0,00 \\
\hline M5-5 Manuseio & 2 & 3 & 4 & 3,50 & 0,71 \\
\hline
\end{tabular}

A documentação do treinamento não tem índices, glossário, referências cruzadas, consultas adicionais bibliográficas, pois receberam em consenso o peso 7 . O manuseio recebeu um peso variando de 3 até 4, ou seja, precisa de uma melhora na forma da apresentação do manual de treinamento, ou seja, no tamanho, peso, qualidade do papel.

Comentário: O resultado indica a falta de qualidade da documentação do treinamento.

A Tabela 4.28 apresenta o resultado da aplicação do Módulo de Avaliação dos serviços técnicos prestados sobre o pacote de software controle de materiais e a seguir o resultado será comentado.

Tabela 4.28 Módulo 6 Serviços Técnicos - Pacote de Software: Controle de Materiais

\begin{tabular}{|l|r|r|r|r|r|}
\hline Módulo 6 Serviços Técnicos - Pacote de Software: Controle de Materiais \\
\hline Palavra Chave & N & Mínimo & Máximo & \multicolumn{1}{|c|}{ Média } & Desvio Padrão \\
\hline M6-1 Atendimento pelo fornecedor & 1 & 4 & 4 & $\mathbf{4 , 0 0}$ & 0,00 \\
\hline M6-2 Contato telefônico & 1 & 4 & 4 & $\mathbf{4 , 0 0}$ & 0,00 \\
\hline M6-3 Tempo hábil para solução do problema & 1 & 4 & 4 & $\mathbf{4 , 0 0}$ & 0,00 \\
\hline
\end{tabular}

Módulo 6 Serviços Técnicos Prestados - Pacote de Software: Controle de Materiais 
Uma pessoa que opera o pacote de software foi entrevistada nesse Módulo de Avaliação e respondeu o questionário. Ela está na seção de Controle de Estoque e Catalogação. Os pesos mais baixos estão próximos da pontuação ideal. As palavras chaves Atendimento pelo fornecedor, contato telefônico, tempo hábil para solução do problema receberam o peso 4. Isto comprova a insatisfação do usuário com a empresa fornecedora do pacote de software.

Módulo 7 Atualização de Versão do Pacote de Software - Pacote de Software: Controle de Materiais

Este modulo não foi aplicado pois o usuário não possui conhecimento técnico para respondê-lo.

\section{Pacote de Software: Controle de Contas a Pagar}

A Tabela 4.29 apresenta o resultado da aplicação do Modulo de Avaliação da adequação do pacote de software ao ambiente empresarial sobre o pacote de software controle de contas a pagar e a seguir o resultado desta tabela será comentado.

Tabela 4.29 Módulo 1 Adequação - Pacote de Software: Controle de Contas a Pagar Módulo 1 Adequação - Pacote de Software: Controle de Contas a Pagar

\begin{tabular}{|l|r|r|r|r|r|}
\hline Palavra Chave & N & Mínimo & Máximo & Média & \multicolumn{1}{l|}{$\begin{array}{l}\text { Desvio } \\
\text { Padrão }\end{array}$} \\
\hline M1-1 Satisfação do usuário & 3 & 2 & 3 & 2,33 & 0,58 \\
\hline M1-2 Completitude & 2 & 2 & 2 & 2,00 & 0,00 \\
\hline M1-3 Fluxos de informações, processos & 3 & 2 & 4 & 3,00 & 1,00 \\
\hline M1-4 Exatidão dos dados & 2 & 2 & 3 & 2,50 & 0,71 \\
\hline M1-5 Importar dados & 3 & 2 & 2 & 2,00 & 0,00 \\
\hline M1-6 Exportar dados & 3 & 2 & 2 & 2,00 & 0,00 \\
\hline M1-7 Acesso ao software & 3 & 5 & 5 & 5,00 & 0,00 \\
\hline M1-8 Outras pessoas utilizam sua área de trabalho & 3 & 1 & 5 & 2,33 & 2,31 \\
\hline M1-9 Confiança & 3 & 2 & 2 & 2,00 & 0,00 \\
\hline M1-10 Interpretação dos dados & 3 & 2 & 5 & 3,33 & 1,53 \\
\hline M1-11 Abrangência do conhecimento & 3 & 2 & 4 & 3,00 & 1,00 \\
\hline M1-12 Outros softwares similares & 3 & 5 & 5 & 5,00 & 0,00 \\
\hline M1-13 Facilidade de utilização & 3 & 2 & 3 & 2,67 & 0,58 \\
\hline M1-14 Operação do software & 3 & 2 & 3 & 2,67 & 0,58 \\
\hline M1-15 Tempo de processamento das funções & 3 & 3 & 4 & 3,33 & 0,58 \\
\hline M1-16 Velocidade do software & 3 & 3 & 4 & 3,33 & 0,58 \\
\hline M1-17 Tempo de impressão & 3 & 3 & 4 & 3,33 & 0,58 \\
\hline M1-18 Instalação do software & 3 & 2 & 2 & 2,00 & 0,00 \\
\hline
\end{tabular}


Módulo 1 Adequação ao Ambiente Empresarial - Pacote de Software: Controle de Contas a Pagar

Três pessoas que operam o pacote de software foram entrevistadas nesse Módulo de Avaliação e todas responderam o questionário com exceção das palavras chaves $M 1-2$ Completitude e M1-4 Exatidão dos dados respondidas por dois usuários. Os três entrevistados são da seção de Análise e Programação Financeira. As palavras chaves estão agrupadas pela pontuação mínima e máxima. Os pesos mais baixos estão próximos da pontuação ideal com exceção das palavras chaves MJ-7 Acesso ao software e M1-8 Outras pessoas utilizam sua área de trabalho que a pontuação mais alta $e$ a ideal.

Satisfação do usuário, exatidão dos dados, facilidade de utilização, operação do software receberam um peso variando de 2 até 3 , ou seja, ocorreu uma discordância de opiniōes mostrando que essas palavras chaves precisam ser melhor direcionadas para que um usuário entrevistado consiga obter uma facilidade na utilização e operação.

Completitude, confiança recebeu o peso 2 , ou seja, foi bem pontuada.

Fluxos de informações e processos, abrangência do conhecimento recebeu um peso variando de 2 até 4, ocorreu uma divergência de opiniōes sendo que apenas um usuário julga que o pacote de software está próximo da realidade da empresa e ele conhece quase todo o pacote de software enquanto outros julgam de maneira contrária.

Importar dados, exportar dados, instalação do software receberam um peso 2, ou seja, o usuário não consegue realizar essas atividades sem a intervenção do analistas de sistemas.

Acesso ao software recebeu em consenso o peso 5. Portanto os usuários não divulgam sua para outras pessoas.

Outras pessoas utilizam sua área de trabalho recebeu peso variando de 1 até 5 , ou seja, existe um usuário que não permite que outras pessoas utilizem sua área de trabalho enquanto outros dois permitem.

Interpretação dos dados recebeu um peso variando de 2 até 5 . Isto significa que um usuário consegue interpretar os dados e mensagens do pacote de software enquanto outro não. 
Os entrevistados não conheciam outros softwares similares recebendo em consenso essa palavra chave o peso 5 .

Tempo de processamento das funçōes, velocidade do software, tempo de impressão receberam um peso variando de 3 até 4, ou seja, necessita de uma melhora nessas palavras chaves.

Comentário: Sugere-se que o usuário faça visitas para outras empresas para conhecer o mesmo ou até outro pacote de software funcionando.

A Tabela 4.30 apresenta o resultado da aplicação do Modulo de Avaliação da qualidade da documentaçāo (manual do usuário) sobre o pacote de software controle de contas a pagar e a seguir o resultado será comentado.

\section{Módulo 2 Qualidade da Documentação - Pacote de Software: Controle de Contas a Pagar}

Duas pessoas que operam o pacote de software foram entrevistadas nesse Modulo de Avaliação e todas responderam o questionário, com exceção das palavras chaves M2-15 Manual de instalação do software, M2-16 Requisitos de hardware e M2-17 Instalação que não foram respondidas e das palavras chaves M2-1 Completitude, M2-2 Consistência, M2-3 Exatidão, M2-4 Interface, M2-11 Glossário, M2-12 Referências cruzadas, M2-13 Consultas adicionais de bibliografia que foram respondidas por um usuário. Os dois entrevistados são da seção de Análise e Programação Financeira. As palavras chaves estão agrupadas pela pontuação mínima e máxima. Os pesos mais baixos estão próximos da pontuação ideal

Completitude, exatidão receberam em consenso o peso 2. Portanto essas palavras chaves receberam uma boa pontuação dos usuários. Consistência, organização receberam o peso 3, ou seja, um usuário julga que a documentação está pouco consistente e os dois que falta organização. Interface recebeu o peso 6 , ou seja, o usuário verificou que a documentação faz referências as interfaces com outros softwares. Apresentação visual, ilustrações receberam um peso variando de 2 até 3, ou seja, um usuário está insatisfeito com a apresentação visual e as ilustrações da documentação. Clareza e exemplos receberam um peso variando de 3 até 4, precisando de uma melhora nessas palavras chaves. Fácil localização, glossário, referências cruzadas, consultas adicionais de bibliografia receberam o peso 2 , ou seja, essas palavras chaves não estão presentes na documentação. 
Tabela 4.30 Módulo 2 Documentação - Pacote de Software: Controle de Contas a Pagar

\begin{tabular}{|l|r|r|r|r|r|}
\hline Módulo 2 Documentação - Pacote de Software: Controle de Contas a Pagar \\
\hline Palavra Chave & N & Mínimo & Máximo & Média & Desvio Padrão \\
\hline M2-1 Completitude & 1 & 2 & 2 & 2,00 & 0,00 \\
\hline M2-2 Consistência & 1 & 3 & 3 & 3,00 & 0,00 \\
\hline M2-3 Exatidão & 1 & 2 & 2 & 2,00 & 0,00 \\
\hline M2-4 Interface & 1 & 6 & 6 & 6,00 & 0,00 \\
\hline M2-5 Organização & 2 & 3 & 3 & 3,00 & 0,00 \\
\hline M2-6 Apresentação visual & 2 & 2 & 3 & 2,50 & 0,71 \\
\hline M2-7 Clareza & 2 & 3 & 4 & 3,50 & 0,71 \\
\hline M2-8 Exemplos & 2 & 3 & 4 & 3,50 & 0,71 \\
\hline M2-9 Ilustrações & 2 & 2 & 3 & 2,50 & 0,71 \\
\hline M2-10 Fácil localização & 2 & 2 & 2 & 2,00 & 0,00 \\
\hline M2-11 Glossário & 1 & 2 & 2 & 2,00 & 0,00 \\
\hline M2-12 Referências cruzadas & 1 & 2 & 2 & 2,00 & 0,00 \\
\hline M2-13 Consultas adicionais de bibliografia & 1 & 2 & 2 & 2,00 & 0,00 \\
\hline M2-14 Manuseio & 2 & 2 & 3 & 2,50 & 0,71 \\
\hline M2-15 Manual de instalação do software & 0 & 0 & 0 & 0,00 & 0,00 \\
\hline M2-16 Requisitos de hardware & 0 & 0 & 0 & 0,00 & 0,00 \\
\hline M2-17 Instalação & 0 & 0 & 0 & 0,00 & 0,00 \\
\hline
\end{tabular}

Comentário: Como sugestão de melhora na qualidade do manual do usuário deveria ser revisto o texto para que o seu entendimento fique mais claro para o usuário e uma melhora na forma da apresentação visual, isto e na qualidade do papel, uso de cores, e deveria possuir mais ilustrações no julgamento de um usuário. Também necessita ocorrer uma melhora na organização da documentação com relação a divisão de assuntos.

Módulo 3 Serviços de Manutenção - Pacote de Software: Controle de Contas a Pagar

Este módulo não foi aplicado pois o serviço de manutenção é realizado através do analista de sistemas da empresa que é acionado e o mesmo entra em contato com a empresa fornecedora do pacote de software caso necessite.

A Tabela 4.31 apresenta o resultado da aplicação do modulo de avaliação da qualidade do treinamento realizado sobre o pacote de software controle de contas a pagar e a seguir o resultado será comentado.

Módulo 4 Treinamento Realizado - Pacote de Software: Controle de Contas de Contas a Pagar 
Três pessoas que operam o pacote de software foram entrevistadas nesse Modulo de Avaliação e todas responderam o questionário com exceçōes das palavras chaves $M 4-5$ Exatidão das informações e M4-7 Apresentação visual que duas pessoas responderam. Os três entrevistados são da seção de Análise e Programação Financeira. As palavras chaves estão agrupadas pela pontuação mínima e máxima. Os pesos mais baixos estão próximos da pontuação ideal com exceção das palavras chaves M4-13 Freqüência de falhas e M4-14 Gravidade da falha que a pontuação mais alta é a ideal.

Tabela 4.31 Módulo 4 Treinamento - Pacote de Software: Controle de Contas a Pagar

\begin{tabular}{|l|r|r|r|r|r|}
\hline Módulo 4 Treinamento - Pacote de Software: Controle de Contas a Pagar \\
\hline Palavra Chave & \multicolumn{1}{|c|}{ Mínimo } & \multicolumn{1}{l|}{ Máximo } & \multicolumn{1}{c|}{ Média } & \multicolumn{1}{c|}{ Desvio Padrão } \\
\hline M4-1 Completitude & 3 & 2 & 4 & 2,67 & 1,15 \\
\hline M4-2 Consistência & 3 & 1 & 3 & 2,00 & 1,00 \\
\hline M4-3 Cronograma & 3 & 1 & 3 & 2,33 & 1,15 \\
\hline M4-4 Satisfação com o treinamento & 3 & 2 & 3 & 2,67 & 0,58 \\
\hline M4-5 Exatidão das informações & 3 & 1 & 8 & 3,67 & 3,79 \\
\hline M4-6 Organização da apresentação & 3 & 1 & 4 & 2,67 & 1,53 \\
\hline M4-7 Apresentação visual & 3 & 6 & 8 & 7,00 & 1,00 \\
\hline M4-8 Clareza, oratoria & 3 & 1 & 3 & 2,00 & 1,00 \\
\hline M4-9 Exemplos & 3 & 2 & 4 & 2,67 & 1,15 \\
\hline M4-10 Ilustrações & 3 & 3 & 4 & 3,33 & 0,58 \\
\hline M4-11 Conceitual e prática & 3 & 1 & 2 & 1,33 & 0,58 \\
\hline M4-12 Consultas adicionais bibliográficas & 3 & 6 & 7 & 6,67 & 0,58 \\
\hline M4-13 Freqüência de falhas & 3 & 3 & 4 & 3,33 & 0,58 \\
\hline M4-14 Gravidade da falha ocorrida & 3 & 6 & 7 & 6,67 & 0,58 \\
\hline
\end{tabular}

Completitude, exemplos receberam um peso variando de 2 até 4, ou seja, ocorreram divergências de opiniões mostrando que foram apresentadas poucas funçōes para apenas um usuário e não foi dado os exemplos necessários para apenas um usuário esclarecer suas dúvidas. Consistência, cronograma, clareza e oratória receberam um peso variando de 1 até 3 , ou seja, necessita de uma melhora nessas palavras chaves para que atendam a maioria dos usuários. Satisfação com o treinamento recebeu um peso variando de 2 ate 3 , isto mostra o descontentamento de dois usuários com essas palavras chaves. Ilustrações, freqüência de falhas receberam um peso variando de 3 até 4, ou seja, existiram poucas ilustraçōes no treinamento e falhas ocorridas. Consultas adicionais de bibliografia e gravidade da falha ocorrida receberam um peso variando de 6 ate 7, ou seja, as poucas falhas que existiram afetaram o treinamento realizado apenas para um usuário a falha prejudicou o treinamento e dois usuários buscaram consultas adicionais de 
bibliografia encontraram enquanto o outro não. $\mathrm{O}$ instrutor precisa melhorar a organização da apresentação, pois recebeu um peso variando 1 até 4, ou seja, ocorreram divergências de opiniões entre os usuários destacando a insatisfação do usuário de dois usuários.

Comentário: A sugestão a ser dada é a realização de um novo treinamento para o usuário que está insatisfeito.

A Tabela 4.32 apresenta o resultado da aplicação do Modulo de Avaliação da qualidade da documentação de treinamento sobre o pacote de software controle de contas a pagar e a seguir o resultado será comentado.

Tabela 4.32 Módulo 5 Documentação de Treinamento - Pacote de Software: Controle de Contas a Pagar

\begin{tabular}{|l|r|r|r|r|r|}
\hline Módulo 5 Documentação do Treinamento - Pacote de Software: Controle de Contas a Pagar \\
\hline Palavra Chave & N & \multicolumn{1}{c|}{ Mínimo } & \multicolumn{1}{c|}{ Máximo } & Média & \multicolumn{1}{l|}{ Desvio Padrão } \\
\hline M5-1 Índices & 3 & 6 & 7 & 6,33 & 0,58 \\
\hline M5-2 Glossário & 2 & 7 & 8 & 7,33 & 0,58 \\
\hline M5-3 Referências cruzadas & 2 & 6 & 8 & 7,00 & 1,00 \\
\hline M5-4 Consultas adicionais bibliográficas & 3 & 7 & 7 & 7,00 & 0,00 \\
\hline M5-5 Manuseio & 3 & 2 & 5 & 3,33 & 1,53 \\
\hline
\end{tabular}

Módulo 5 Documentação de Treinamento - Pacote de Software: Controle de Contas a Pagar

Três pessoas que operam o pacote de software foram entrevistadas nesse Módulo de Avaliação e responderam o questionário com exceção das palavras chaves M5-2 Glossário e M5-3 Referências cruzadas que apenas dois usuários responderam. Os três são da seção de Análise e Programação Financeira. As palavras chaves estão agrupadas pela pontuação mínima e máxima. Os pesos mais baixos estão próximos da pontuação ideal.

Indices, referências cruzadas receberam um peso variando de 6 até 7, ou seja, algumas duas pessoas verificaram que a documentação apresentava essas palavras chaves enquanto a outra não. A documentação do treinamento não apresentava glossário e nem consultas adicionais de bibliográficas, ou seja, receberam o peso 7. Manuseio recebeu um peso variando de 2 ate 5 , isto indica a necessidade de uma melhora na forma de apresentação da documentação do treinamento para facilitar o manuseio. 
Comentários: Precisa-se melhorar a qualidade da documentação do treinamento no que refere-se a facilidade no manuseio.

A Tabela 4.33 apresenta o resultado da aplicação do Módulo de Avaliação da qualidade dos serviços técnicos prestados pela empresa fornecedora do software sobre o pacote de software controle de contas a pagar e a seguir o resultado será comentado.

Tabela 4.33 Módulo 6 Serviços Técnicos - Pacote de Software: Controle de Contas a Pagar

\begin{tabular}{|l|r|r|r|r|r|}
\hline Módulo 6 Serviços Técnicos - Pacote de Software: Controle de Contas a Pagar \\
\hline Palavra Chave & N & Mínimo & Máximo & Média & Desvio Padrão \\
\hline M6-1 Atendimento pelo fornecedor & 3 & 3 & 4 & 3,33 & 0,58 \\
\hline M6-2 Contato telefônico & 3 & 1 & 3 & 2,33 & 1,15 \\
\hline M6-3 Tempo hábil para solução do problema & 3 & 3 & 3 & 3,00 & 0,00 \\
\hline
\end{tabular}

\section{Módulo 6 Serviços Técnicos Prestados - Pacote de Software: Controle de Contas a Pagar}

Três pessoas que operam o pacote de software foram entrevistadas nesse Módulo de Avaliação e todas responderam o questionário. Os três entrevistados são da seção de Análise e Programação Financeira. Os pesos mais baixos estão próximos da pontuação ideal.

Atendimento pelo fornecedor recebeu um peso variando de 3 ate 4, ou seja, precisa melhorar 0 atendimento pela empresa fornecedora do pacote de software para que um usuário fique satisfeito. Os usuários estão satisfeitos com o contato telefônico, pois recebeu um peso variando de 1 até 3 . Tempo hábil para a solução do problema recebeu em consenso o peso 3, pois o problema do usuário foi solucionado no prazo pela empresa fornecedora do pacote de software para o usuário efetuar as suas tarefas.

Comentário: Como sugestão verifica-se que necessita ocorrer uma melhora no atendimento de um usuário pela empresa fornecedora do pacote de software, então pode-se dizer em geral que os serviços técnicos prestados são bons.

A Tabela 4.34 apresenta o resultado da aplicação do Módulo de Avaliação da atualização da versão sobre o pacote de software controle de contas a pagar e a seguir o resultado será comentado. 
Tabela 4.34 Módulo 7 Atualização de Versão - Pacote de Software: Controle de Contas a Pagar

\begin{tabular}{|l|r|r|r|r|r|}
\hline Módulo 7 Atualização da Versão - Pacote de Software: Controle de Contas a Pagar \\
\hline Palavra Chave & N & \multicolumn{1}{c|}{ Mínimo } & \multicolumn{1}{c|}{ Máximo } & Média & Desvio Padrão \\
\hline M7-1 Implantação da nova versão & 2 & 6 & 6 & 6,00 & 0,00 \\
\hline M7-2 Necessidade de novas funções & 2 & 1 & 1 & 1,00 & 0,00 \\
\hline M7-3 Melhoria nas funções existentes & 1 & 1 & 8 & 4,50 & 4,95 \\
\hline M7-4 Substituição da funções & 0 & 8 & 8 & 8,00 & 0,00 \\
\hline M7-5 Mudanças de processos & 1 & 4 & 8 & 6,00 & 2,83 \\
\hline M7-6 Automatização de processos & 2 & 3 & 4 & 3,50 & 0,71 \\
\hline M7-7 Teste da nova versão & 0 & 8 & 8 & 8,00 & 0,00 \\
\hline
\end{tabular}

Módulo 7 Atualização de Versão do Pacote de Software - Pacote de Software: Controle de Contas a Pagar

Duas pessoas que operam o pacote de software foram entrevistadas nesse Módulo de Avaliação e responderam o questionário com exceção das palavras chaves $M 7-3$ Melhoria nas funções existentes e M7-5 Mudanças de processos que apenas um respondeu e das palavras chaves M7-4 Substituição da funções e M7.7 Teste da nova versão que nenhum usuário respondeu. Os entrevistados são da seção de Análise e Programação Financeira. Os pesos mais baixos estão próximos da pontuação ideal.

Implantação da nova versão recebeu o peso 6 , ou seja, os usuários entendem que o momento é adequado para a atualização da versão.

Necessidade de novas funções, melhoria nas funções existentes receberam o peso 1, isto significa que os dois usuários sentem bastante necessidade de novas funções.

Mudanças de processo recebeu o peso 4. As mudanças ocorridas no setor foram insignificantes.

Automatização de processos recebeu um peso variando de 3 até 4 , ou seja, os usuários entendem que poucos processos estāo automatizados na empresa. Portanto a empresa deve automatizar os processos que ocorrem manualmente na área de contas a pagar.

Comentário: A conclusão é que deve-se efetuar a atualização de versão do pacote de software. 


\section{Comentários Sobre os Módulos de Avaliação}

Quanto à adequação do pacote de software ao ambiente empresarial, verificou-se que os pacotes de software folha de pagamento e administração de recursos humanos, controle de materiais, controle de contas a pagar mantiveram a mesma conceituação por parte dos usuários, divergindo bastante do contexto o pacote de software contabilidade i para o menos adequado e o pacotes de software controle de ponto eletrônico e contabilidade ii para os mais adequados. Também vale salientar que com exceção do controle de ponto eletrônico os usuários não sabem instalar o pacote de software devido à complexidade do ambiente. Os usuários não consegucm importar e exportar os dados necessários para o seu trabalho causando uma dependencia dos analistas de sistemas com relação à integração dos pacotes de software utilizados e à manipulação dos dados. Sugere-se a compra de uma ferramenta para extrair os dados para que os proprios usuários confeccionem seus relatórios. A dificuldade de efetuar a importação e exportação dos dados pelo usuário prejudica a integração dos pacotes de software e isso reflete nas áreas da empresa. Deve-se desenvolver um estudo para analisar e indicar propostas para a integração dos pacotes de software na área administrativa e financeira.

Quanto à qualidade da documentação (manual do usuário) verificou-se que os usuários sentem a falta de exemplos e não estão satisfeitos com o tamanho e o peso do manual, com exceção da contabilidade ii e controle de ponto eletrônico e as ilustrações deixam a desejar em todos os manuais dos pacotes de software analisados. A sugestão é encaminhar os comentários levantados neste trabalho para a empresa fornecedora do pacote de software.

Os serviços de manutenção prestados obtiveram quase que a mesma conceituação, o que torna bem próximo os pacotes de software pesquisados (folha de pagamento e administração de recursos humanos, controle de materiais, controle de ponto eletrônico) e não foram bem avaliados pelos seus usuários mostrando que as empresas que prestam os serviços de manutenção precisam melhorar seus serviços nas palavras chaves pesquisadas para satisfazer seus clientes. A sugestão é a revisão no contrato de manutençāo com as empresas fornecedoras do pacote de software, principalmente no atendimento das solicitações do usuário.

Quanto ao modulo treinamento realizado verifica-se que os usuários do pacote de software controle de materiais são os que mais ficaram insatisfeitos, e grande parte dos usuários dos pacotes 
analisados ficaram insatisfeitos com o cronograma do treinamento. Sugere-se a criação de um plano de treinamento do usuário operacional do pacote de software.

Quanto ao módulo documentação de treinamento verificou-se que os pacotes controle de materiais e controle de contas a pagar e folha de pagamento e administração de recursos humanos obtiveram uma conceituação bem próxima e os usuários estavam insatisfeitos com o tamanho e peso da documentação, com exceção da documentação do pacote da folha de pagamento.

Quanto ao módulo serviços técnicos prestados observou-se que os usuários dos pacotes de software em sua grande maioria estão insatisfeitos com os serviços técnicos prestados pela empresa fornecedora do software, com exceção do pacote de software contabilidade ii.

Quanto ao módulo atualização de versão do pacote de software observou-se que os usuários perceberam que existe a necessidade da atualização de versão dos pacotes de software analisados para este módulo (contabilidade ii, controle de ponto eletrônico, folha de pagamento e administraçāo de recursos humanos e controle de contas a pagar).

\section{Classificação dos Pacotes de Software no Contexto Empresarial}

Levando em consideração o ponto de vista do usuário operacional, em geral, podem-se classificar os pacotes de software, quanto a qualidade destes, na seguinte ordem decrescente: Contabilidade ii, Controle de Ponto Eletrônico, Folha de Pagamento e Administraçāo de Recursos Humanos, Controle de Contas a Pagar, Controle de Materiais, Contabilidade i. O objetivo desta classificação é dar informações para que o tomador de decisão consiga priorizar o auxilio da informática nas áreas que estão os pacotes de software.

\section{Impacto na Administração}

O gerente tomou duas decisões diante da situação apresentada pela pesquisa. A primeira decisão foi proposta para a empresa Ceterp uma negociação junto as empresas fornecedoras do pacote de software para solucionar os problemas detectados por este trabalho e também a contratação de uma assessoria para organizar os fluxos e processos na empresa, pois um dos objetivos da empresa é colocar novamente em operação o sistema de contabilidade i que deixou de 
ser utilizado pelo usuário e a implantação do pacote de software administração de compras. Atualmente a primeira decisão está sendo executada e a empresa terá as áreas administrativa e financeira automatizadas com uma melhora na qualidade da tecnologia da informação. A Segunda decisão é a realização da troca dos pacotes de software administrativos e financeiros por outros disponíveis no mercado e só seria realizada após a execução da primeira da decisão diante dos investimentos exigidos. Cabe salientar, como ação da primeira decisão já ocorreu um investimento na capacitação dos empregados quanto ao treinamento na utilização dos pacotes de software.

\subsection{Considerações Finais}

Neste capítulo foi apresentado um estudo de caso realizado como projeto piloto deste trabalho. Assim, pode se observar alguns benefícios introduzidos:

Introdução na empresa de um mecanismo de avaliação para um controle do contexto da qualidade do parque de pacote de software em operação, obtendo informações para tomada de decisão gerencial, auxiliando o gerente em sua negociação com os fornecedores do pacote de software na renovação do contrato de manutenção do pacote de software, buscando novas tecnologias no mercado, obtendo uma maior aproximação com os anseios dos usuários dos pacotes de software.

Início da criação do histórico de dados dos pacotes de software avaliados que poderá ser aproveitado para os proximos trabalhos desenvolvidos na empresa como uma necessidade por parte da empresa da continuidade do acompanhamento do controle qualidade do pacote de software implantado.

As recomendações sugeridas para cada pacote de software nos comentários do resultado da análise dos módulos de avaliações aplicados.

Estruturaçāo da avaliação em modulos que permite atender objetivos diferentes e o uso da palavra chave que facilitou em muito o entendimento do usuário sobre as questōes. Verificou-se através da pesquisa de campo realizada que houve uma grande aceitação por parte do usuário que opera o sistema de falar sobre o pacote de software que ele utiliza e do que precisaria ser melhorado 
para atendê-lo e neste ponto o questionário foi de grande valia pois ajudou em muito na organização da entrevista, melhorando e criando um canal de comunicação com o usuário.

Uma limitação encontrada na pesquisa foi em relação à capacitação do usuário do pacote de software, pois poucos deles sabem utilizar todo o pacote de software porque não participaram do treinamento de todo o sistema, muitos conhecem e possuem interesse apenas pelos modulos e funções referentes a sua área de trabalho.

No capítulo seguinte será apresentada a conclusão deste trabalho. 


\section{Capítulo 5}

\section{CONCLUSÃO}

\subsection{Conclusão}

A abertura do mercado nacional para as importações impulsionou a busca pela qualidade de software fazendo do software o grande negócio de hoje e do futuro segundo Weber [WEB97], com projeção de faturamento para o ano 2000 de um trilhão de dólares. O resultado é um aumento considerável da oferta e evolução de pacotes de software de sistemas de informação tornando a sua seleção difícil para as pessoas que não são técnicas na área de engenharia de software. Então, é evidente a necessidade de realizar a avaliação da qualidade de produto de software na empresa, pois o pacote de software que foi escolhido e está sendo utilizado poderá influenciar o seu negócio e esses resultados também poderão ajudar na seleção dos próximos pacotes de software a serem comprados.

Este trabalho teve como objetivo a proposição de um método para avaliação baseado principalmente nas características de qualidade de pacotes de software em operação na área de sistemas de informação, ou seja, mostrar um diagnóstico da situação atual em que se encontram os pacotes de software em operação dentro de uma empresa. Para isto foram desenvolvidos módulos de avaliaçōes dos pacotes de software (adequação na empresa, qualidade da documentação, serviços de manutenção, treinamento realizado, documentação de treinamento, serviços técnicos prestados, necessidade da atualização de versão do pacote de software) na área de sistemas de informações, levando em consideração as características de qualidade de produto de software da ISO/IEC 9126. A aplicação dos módulos de avaliação de acordo com os objetivos traçados auxiliou o gerente na tomada de decisão em relação aos pacotes de software avaliados. 
Para a identificação da situaçāo em que se encontra o parque de pacote de software instalado foi feita uma pesquisa empírica, utilizando do método Goal/Question/Metric-GQM, através de um estudo de caso realizado na empresa Ceterp - Centrais Telefônicas de Ribeirão Preto S/A, onde foram avaliados 6 pacotes de softwares em operação na área de sistemas de informação.

O trabalho contribuiu com a empresa Ceterp pois os tomadores de decisão obtiveram informações que os auxiliaram na melhoria da qualidade da tecnologia da informação nas áreas em que se encontravam os pacotes de software em operação.

\subsection{Trabalhos Futuros}

A partir do resultado deste trabalho, algumas linhas de pesquisa podem ser sugeridas.

Aplicação periódica do método de avaliação para observar as mudanças ocorridas no contexto empresarial com as tomadas de decisões gerenciais, no caso da empresa Ceterp, por exemplo, após a decisão de realizar um treinamento aplicar o módulo de avaliação de treinamento com o proposito de avaliar a qualidade do treinamento realizado.

Realização de novos estudos empirícos para verificar a adequação do método para avaliação da qualidade de pacotes de software na área de sistemas de informação em outras empresas.

Criação de novos módulos de avaliações relacionados com o pacote de software como, por exemplo, o que avalia a apresentação do vendedor do pacote de software, se o objetivo for a compra de um pacote de software.

Outra linha de pesquisa a ser enderaçada é a qualidade da implantação do pacote de software, ou seja, dos serviços pós venda, pois influência a qualidade de um pacote de software em operação na área de sistemas de informação em uma empresa. Às vezes, pode ocorrer do pacote de software ser bem conceituado no mercado e não conseguir adequar-se na empresa pois os serviços pós venda não são bem realizados. 


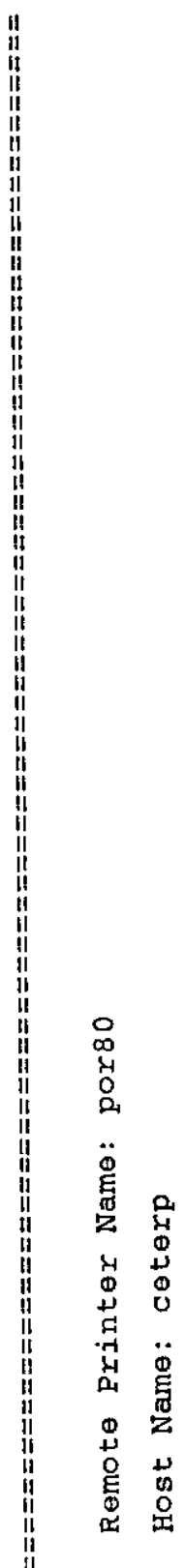




\begin{tabular}{|c|c|c|}
\hline \# & $\#$ & \# \\
\hline \# & \# & \#\# \\
\hline \#\#\#\#\# & $\#$ & \# \#\# \\
\hline \# & $\#$ & \# \\
\hline \# & $\#$ & $\#$ \\
\hline$\#$ & $\#$ & $\#$ \\
\hline
\end{tabular}




\section{REFERÊNCIAS BIBLIOGRÁFICAS}

[BAS81] BASILI, V. R. Data Collection, Validation, and Analysis. Tutorial on Models and Metrics for Software Management and Engineering. IEEE, p.310-13,1981. (catalog n.EHO167-7)

[BAS84] BASLI, V. R.; WEISS, D. M. A Methodology for Collecting Valid Software Engineering Data. IEEE Transactions on Software Engineering, v.SE-10,n.6, p.728-38, 1984.

[BAS85] BASILI, V. R. Quantitative Evaluation of Software Engineering Methodology. In Plan Pacific Computer Conference, Melbourne, Austrália, Também disponível como Relatorio Técnico TR-1519, department of Computer Science, University of Maryland, College Park, MD July 1985.

[BAS86] BASILI, V. R.; SELBY, R. W.; HUTCHENS, D. H. Experimentation in Software Engineering. IEEE Transaction on Software Engineering, v.12,n.7,p.33-743, 1986.

[BAS88] BASIII, V. R.; ROMBACH, H. D. The Tame project: Towards Improvement-Oriented Software Environments IEEE Transactions on Software Engineering, v.14, n.6, p.758-73, 1988 .

[BAS90] BASILI, V. R. Viewing Maintenance as Reuse-Oriented Software Development. IEEE Software, p.19-25, 1990.

[BAS91] BASILI, V. R. e SELBY, R. W. Paradigmas For Experimentation and Empirical Studies in Software Engineering Realibility Engineering and System Safety 132 (1991) 171-191

[BAS92] BASIII, V. R.; et al. The Software Engineering Laboratory: An Operational Software Experience Factory. IEEE Computer Society, May, p.370-81, 1992.

[BAS94] BASILI, V. R.; CALDIEIRA, G.; ROMBACH, D. The Goal Question Metric Approach. In: Encyclopedia of Software Engineering, Wiley, 1994.

[BEL92] BELCHIOR, ARNALDO DIAS Controle da Qualidade de Software Financeiro. Rio de Janeiro, 1992. Dissertação (Mestrado). Universidade Federal do Rio de Janeiro.

[BRI94] BRIAND, L; MORASCA, S.; BASILI, VICTOR R. Goal-Driven Definition of Product Metrics Basead on Properties, College Park, University of Maryland, 1994. (Computer Science Technical report series, CS-TR-3346) 
[CTI94] FUNDAÇĀO CENTRO TECNOLÓGICO PARA INFORMÁTICA. Tecnologia para Avaliação da Qualidade de Software TAQS. 1994.

[CON85] CONNOR, U. Como Escolher e Comprar um Microcomputador Profissional. Tradução de Sylvia Nobrega, Rio de Janeiro, SCI Editora, 1985.

[CTI96] FUNDAÇÃO CENTRO TECNOLOGICO PARA INFORMÁTICA Modelos de Processo de Software: Visão Global e Análise Comparativa. 1996.

[DEM86] DEMING, W. E. Out of the Crisis. Cambridge Center for Advanced Study, Massachusetts Institute of Technology, 1986.

[GAL91] GALLAGHER; LYLE Using Program Slincing in Software Maintenance. IEEE Transaction On Software Engineering, v.17,n.8,p.751-61, 1991.

[GRA87] GRADY, R. B.; CASWELL, L. D. Software Metrics - Establishing a Company Wide Program. Prentice Hall, 1987.

[HUM89] HUMPHREY, W. S. Managing the Software Process. Massachusetts, AddisonWesley, 1989.

[ISO/IEC International Standard - Information Technology - Software Packages - Quality 12119] Requeriments and Testing, October, 1994.

[ISO/IEC Information Technology - Evaluation of Software Product - Parts: Evaluator's Guide 14598]

[ISO/IEC- Information Technology - Software Product Evaluation - Quality Characteristics And 9126] Guidelines For Their Use, December, 1991.

[ISO-9000] Quality Management and Quality Assurance Standards: Guideline For Selection And Use. Genebra, Suiça, 1987.

[ISO-9001] Quality Systems: Model For Quality Assurance in Design, Development, Production, Installation and Servicing. Genebra, Suiça, 1987.

[ISO-9002] Quality Systems: Model For Quality Assurance in Production and Installation. Genebra, Suiça, 1987.

[ISO-9003] Quality Systems: Model for Quality Assurance in Final Inspection and Test. Genebra, Suiça, 1987. 
[ISO-9004] Quality Systems and Quality System Elements. Genebra, Suiça, 1987.

[ISO-9000- Quality Systems: Model for Quality Assurance in Design, Development, Production, 3] Installation and Servicing. Genebra, Suiça, 1987.

[MCC77] McCALL, J.; RICHARDS, P.; WALTERS, G. Factors in Software Quality, NTIS AD-A049-014, 015,055, Nov., 1997.

[MCC79] McCALL, J. A. An Introduction to Software Quality Metrics, in Software Quality Management. New York, Petrocelli Books, Inc., 1979.

[MCC85] McCALEB, R. B. A Microinformática na Empresa. Tradução SISTECH - Sistemas Tecnologicos para Competência Humana. Rio de Janeiro, LTC - Livros Técnicos e Científicos Editora S. A., 1985.

[NBR- Tecnologia de Informação - Avaliação de produto de software - Características de 13596] qualidade e diretrizes para o seu uso (Versão em português da Norma ISO/IEC 9126).

[NOG86] NOGUEIRA, A. R. R.; GARCIA, J M. P. P. L. Avaliação e Seleção de Sistemas: Um Enfoque da Tecnologia da Informação. Rio de Janeiro, LTC - Livros Técnicos e Cientifícos Editora S. A., 1986.

[OL97] OlIVEIRA, A. P. de; RÊGO, C. M.; SOUZA, E. P. de; AGUAYO, M. T. V., COLOMBO, R. M. T., LOPES, S. R.; MAINTINGUER, S. T. La Experiencia Del Brasil en La Aplicación de Normas para Evaluación de La calidad de Producto de Software. Santiago, Chile, novembro, 1997.

[PAN84] PANELL, B. K.; JACKSON, S. B.; LUCAS, S. B. El Microordenador En La Pequenã Empresa. Madrid, Paraninfo, 1984.

[PLO84] PLOCIAK, M; SALY, A. Seven Simple Steps to Buying a Computer for Your Business. New York, Warner Books, Inc., 1984.

[PRE94] PRESSMAN, R.S. Software Engeneering - A Practitioner's Approach - European 3Rev. Ed. McGrall-Hill Book Co., 1994.

[KAN94] KAN, S. H.; BASILI, V. R.; SHAPIRO, L. N. Software Quality: Na Overview from the Perspective of Total Quality Management. IBM Systems Journal, v.33, n. 1,p.4$19,1994$.

[KHO94] KHOSHGOFTAAR, T. M.; OMAN, P. Software Metrics: Charting the Course. IEEE Computer, p.13-15, 1994. 
[KIT96] KITCHENHAM, B.; PFLEEGER, S.L. Software Quality: The Elusive Target. IEEE Software, p.12-21, 1996.

[RAD85] RADICE, R. A.; et al. Programming Process Study. IBM Systems Journal, v.24, n.2, p.91-101, 1985.

[ROC87] ROCHA, A. R. C. Análise e Projeto Estruturado de Sistemas. Rio de Janeiro, Editora Campus, 1987.

[ROM87] ROMBACH, H. D. e BASILI, V. R. Quantitative Assessment of Sotware Maintenance: An Industrial Case Study. In:. Conf. Software Maintenance, Austin, TX, p. 134-144

[ROM89] ROMBACH, H. D. Improving Software Maintenance Through Measurement. Proceedings of the IEEE, v.77., n.4, p.581-95, 1989.

[ROM90] ROMBACH, H. D. Design Measurement: Some Lessons Learned. IEEE Software, p.17-24, 1990.

[SAN94] SANCHES, R. A Influência do Software e de seu Processo de Manutenção no Esforço de Manutenção -São Paulo, 1994. Dissertação (Mestrado). Faculdade de Economia, Administração e Contabilidade da USP.

[SCH84] SCHULMAN, R. e PLOCIA, F. M. Seven Simple Steps to Buying a Personal Computer. New York. Warner Books, Inc., 1984.

[SEI84] SEIDMAN, A e ARBEL , A. Microcomputer Selection Process for Organization Information Management. Information \& Management, n.7, p.317-329, 1984.

[SIB85] SIBLEY, E. H. How to Select and Evaluate a DBMS. Journal of Information Systems Management, p.23-31, 1984.

[SHE90] SHEPPERD, M. Design Metrics: An Empirical Analysis. Software Engineering Journal, v.5, n.1, p.3-10, 1990.

[SHI96] SHIN, H. e LEE, J. A Process Model of Aplication Software Package Acquisition and Implementation. J. Systems Software, p.57-64, 1996.

[SOL95] SOLINGEN, R. Goal - Oriented Software Measurement in Praticse: Introducing Software Measurement in Schlumberger Retail Petroleum Systems, Master Thesis Report, Schumberger, 1995.

[SPI95] ROOT, P. T. SPICE: A Framework for Software Process Assesment, Improvement and Practice, Pilot Issue, p.75-56, 1995.

[SPS84] SPSS/PC; SSPS for IBM PC/XT; SPSS Inc. USA, 1984. 
[SPS96] SPSS for Windows Student Version. Release 7.5, Dec. 6, 1996.

[TSU96] TSUKUMO, A. N.; OLIVEIRA, A. A. A. C. P.; REGO, C. M.; AZEVEDO, G. F.; MALDONADO, J. C.; AGUAYO, M. T. V.; JINO, M.; TUTUMI; R. ISO/EC 9126: An Experiment of Application on Brazilian Software Products

[TSU97] TSUKUMO, A. N.; RÊGO, C. M.; AZEVEDO, G. F.; MENEGHETTI, L. K.; COSTA, M. C.; CARVALHO, M. B. de; COLOMBO, M. T. Qualidade de Software: Visões de Produto e Processo de Software. II Escola Regional de Informática da Sociedade Brasileira de Computação Regional de São Paulo - II ERI da SBC. Piracicaba, Junho, p.173-89, 1997.

[URD93] URDAN, A. T. Qualidade de Serviço: Proposição de um Método Integrativo -Sāo Paulo, 1993. Dissertação (Mestrado). Faculdade de Economia, Administração e Contabilidade da USP.

[VID89] VIDAL, A. G. Clipper Versão Summer 87 v.I v.II. Rio de Janeiro, LTC Livros Técnicos e Científicos Editora S.A., 1989.

[VID90] VIDAL, A. G. R. Seleção de Pacotes de Software Administrativo para Microcomputadores na Pequena e Média Empresa - Um Estudo Exploratório São Paulo, 1990. Dissertação (Mestrado). Faculdade de Economia e Administracão da USP.

[YU89] - YU, J. W. e HARRISON, P. Selecting Business Software. Homewood Illinois, Richard D. Irwin, Inc., 1989.

[WEB97] WEBER, C. K.; LUCA, J. C. M. D.; ROCHA, A. R. C. D. Qualidade e Produtividade em Software: Termo de Referência do Subprograma Setorial da Qualidade e Produtividade em Software, do Programa Brasileiro da Qualidade e Produtividade PBQP - 2 edição revisada e ampliada. São Paulo, Makron Books, 1997.

[WER94] WERNECK, D. O Movimento da Qualidade, Folha de São Paulo, São Paulo, março (Fascículo SEBRAE - Qualidade Total), 1994. 


\title{
Anexo 1
}

\section{Questionário de Avaliação da Qualidade de Pacotes de Software na Área de Sistemas de Informação}

\author{
Dados Sobre o Entrevistado
}

Empresa:

Nome do entrevistado:

Cargo: Setor:

Telefone: Ramal:

\section{Dados Sobre o Pacote de Software Instalado}

Pacote de Software:

Versão: Telefone suporte Técnico:

Mes e Ano em que entrou em operação:

Empresa Fornecedora do pacote:

\section{Módulos de Avaliação}

$1 \square$ Adequação do Pacote de Software ao Ambiente Empresarial

$2 \square$ Qualidade da Documentação (manual do usuário, manual do sistema)

$3 \square$ Serviços de Manutenção

$4 \square$ Treinamento Realizado

$5 \square$ Documentação de Treinamento

$6 \square$ Serviços Técnicos Prestados

$7 \square$ Atualização de Versão do Pacote de Software (nova versão) 


\section{MÓDULO 1 - Adequação do Pacote de Software ao Ambiente Empresarial}

M1-1 Você está satisfeito com o software (palavra chave : satisfação do usuário)

$\square$ Bastante $\square$ Suficiente $\quad \square$ Pouco $\square$ Muito pouco $\square$ Não

M1-2 As funç̃̃es desejadas por você e pelas outras pessoas estão implementadas no software (palavra chave: completitude)

$\square$ Todas $\square$ Quase todas $\square$ Poucas $\square$ Muito poucas $\square$ Não

M1-3 O software está próximo da realidade da empresa (palavra chave: fluxos de informaçōes, processos)

$\square$ Bastante $\square$ Suficiente $\square$ Pouco $\square$ Muito pouco $\square$ Não

M1-4 Os dados utilizados pelo software estão corretos e atualizados (palavra chave: exatidão dos dados)
口 $80 \sim 100 \%$ 口 $60 \sim 79 \%$
ㅁ $40 \sim 59 \%$
$20 \sim 39 \%$
$0 \sim 19 \%$

M1-5 Você consegue os dados necessários de outros software de outras áreas, via software, ou seja, sem a interferência do analista de sistemas (palavra chave: importar dados)
$\square \operatorname{Sim}$
口 Năo
Não sei

M1-6 Você consegue disponibilizar os dados para outras pessoas de outras áreas, via software, ou seja, sem a interferência do analista de sistemas (palavra chave: exportar dados)
$\square \operatorname{Sim}$
ロ Não
Não sei

M1-7 Alguém, além de você, conhece sua senha de acesso ao software (palavra chave: acesso ao software)
$\square$ Mais de 3
$\square 3$ Pessoas
$\square 2$ pessoas
1 pessoa

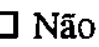

M1-8 Você deixa outras pessoas utilizarem sua área de trabalho (palavra chave: outras pessoas utilizam sua área de trabalho)
$\square$ Mais de 3
ㅁ 3 Pessoas
$\square 2$ pessoas
1 pessoa
口 Não

M1-9 Você confia no software (palavra chave: confiança)
ㅁ $80 \sim 100 \%$
ㅁ $60 \sim 79 \%$
$40 \sim 59 \%$
ㄴ 20 39\%
ㅁ 0 19\% 
M1-10 Você sabe interpretar os resultados e as mensagens fornecidas (palavra chave: interpretação dos dados)
$\square$ Todas
Quase todas
$\square$ Poucas $\square$ Muito poucas
$\square$ Não

M1-11 Você conhece o software (palavra chave: abrangência do conhecimento)
$\square$ Todo
Quase todo
$\square$ Pouco
Muito pouco
$\square$ Não

M1-12 Você conhece outros softwares similares (palavra chave: outros softwares similares)
Mais de 3
③
$\square 2$
$\square 1$
$\square$ Não

M1-13 O software é fácil de utilizar, apreender (palavra chave: facilidade de utilização)

$\square$ Bastante $\square$ Suficiente $\square$ Pouco $\square$ Muito pouco $\square$ Não

M1-14 Você sabe operar o software (palavra chave: operação do software)
$\square$ Todo
$\square$ Quase todo
$\square$ Pouco
$\square$ Muito pouco
$\square$ Não

M1-15 Você está satisfeito com o tempo de processamento das funções do software (palavra chave: tempo de processamento das funções)
$\square$ Excelente
$\square$ Ótimo
$\square$ Bom
$\square$ Regular
Péssimo

M1-16 Você está satisfeito com a velocidade do software (palavra chave: velocidade do software)
$\square$ Excelente
$\square$ Ótimo
$\square$ Bom
Regular
Péssimo

M1-17 Você está satisfeito com o tempo de impressão de seus relatórios (palavra chave: tempo de impressão)
$\square$ Excelente $\square$ Ótimo
Bom $\square$ Regular
Péssimo

M1-18 Você sabe instalar o software, se a intalaçāo puder ser feita pelo usuário (palavra chave: instalação do software)
$\square \operatorname{Sim}$
$\square$ Não
$\square$ Não sei 


\section{MÓDULO 2 - Qualidade da Documentação (manual)}

M2-1 As funçōes do software estão descritas na documentação (palavra chave: completitude)
$\square$ Todas
Quase todas
$\square$ Poucas
$\square$ Muito poucas
$\square$ nenhuma

M2-2 As informações apresentadas na documentação estão de acordo com as funções do software e livre de inconsistências internas com cada termo possuindo um significado único em toda documentação (palavra chave: consistência)
$\square$ Todas
$\square$ Quase todas
$\square$ Poucas
$\square$ Muito poucas
$\square$ Nenhuma

M2-3 As informações apresentadas na documentação são corretas para a operação e funcionamento do software (palavra chave: exatidāo)
$\square$ Todas
$\square$ Quase todas
$\square$ Poucas
$\square$ Muito poucas
Não

M2-4 A documentação faz referências a interfaces com outros software de outras áreas (palavra chave: interface)
$\square \operatorname{Sim}$
Não
$\square$ Não sei

M2-5 A documentação apresenta-se de forma organizada, por exemplos: divisão de capítulos, tópicos, assuntos (palavra chave: organização)
$\square$ Toda
$\square$ Quase toda
$\square$ Pouca
$\square$ Muito pouca
Não

M2-6 A apresentação visual da documentação é agradável (palavra chave: apresentação visual)
$\square$ Muito
$\square$ Suficiente
$\square$ Pouco
Muito pouco
Não

M2-7 O texto da documentação é bem redigido e não possui ambiguidade possibilitando o esclarecimento das funçōes (palavra chave: clareza)
$\square$ Todo
$\square$ Quase todo
$\square$ Pouco
Muito pouco
Não

M2-8 Os exemplos utilizados na documentação foram suficientes e adequados ao esclarecimento de suas dúvidas (palavra chave: exemplos)
Todos
$\square$ Quase todos
$\square$ Poucos
$\square$ Muito poucos $\square$ Não possui

M2-9 As ilustraçōes (gráficos, desenhos, figuras) são suficientes e adequadas ao esclarecimento das informaçōes necessárias ao seu uso (palavra chave: ilustrações)
Todas
Quase todas
$\square$ Poucas
Muito poucas
Não possui 
M2-10 A documentação possui índices gerais e remissivos completos e bem organizados que permite a facilidade para você encontrar informaçōes (palavra chave: fácil localização)

$\square \operatorname{Sim} \quad \square$ Não $\quad \square$ Não sei

M2-11 A documentação possui glossário dos termos técnicos para o seu esclarecimento. Exemplos: dicionário explicando o que é on-line, batch (palavra chave: glossário)
$\square \operatorname{Sim}$
口 Não
$\square$ Não sei

M2-12 Possui referências cruzadas possibilitando que você encontre a informação desejada (palavra chave: referências cruzadas)
$\square \operatorname{Sim}$
口 Nào
$\square$ Não sei

M2-13 A documentação possui indicações para consultas adicionais (livros técnicos, bibliografias) disponíveis para você (palavra chave: consultas adicionais de bibliografia)
$\square \operatorname{Sim}$
ロ Não
$\square$ Não sei

M2-14 A forma de apresentação do manual do software garante facilidade de manuseio. Exemplo: tamanho, peso. (palavra chave: manuseio)
$\square$ Bastante
$\square$ Suficiente
ㅁ Pouca
$\square$ Muito pouca
Nenhuma

M2-15 Apresenta requisitos de software. Exemplo: indicação de quantidade de memoria para instalar o software, versão (palavra chave: manual de instalação do software)
$\square \operatorname{Sim}$
口 Não
Não sei

M2-16 Apresenta requisitos de hardware (palavra chave: manual de instalação, configuração mínima de hardware, requisitos de hardware)
$\square$ Sim
ロ Não
$\square$ Não sei

M2-17 A documentação faz referências se você pode ou não instalar o software (palavra chave: instalação)
$\square \operatorname{Sim}$
口 Não
Não sei 


\section{Módulo 3 - Serviços de Manutenção}

M3-1 Existe a atualização da documentação (palavra chave: atualização da documentação)
$\square \operatorname{Sim}$
ロ Não
口 Não sei

M3-2 As mudanças legais necessárias ocorridas no software foram realizadas em tempo hábil para você executar suas tarefas no prazo determinado (palavra chave: atualização do software em tempo hábil para solução do problema)

$\square$ Muito antes $\square$ Antes do prazo $\square$ No prazo $\square$ Fora do prazo $\square$ Não

M3-3 A empresa disponibiliza as novas versões do software (palavra chave: novas versōes)

$\square \operatorname{Sim} \quad \square$ Não $\quad \square$ Não sei 


\section{MÓDULO 4 - Treinamento Realizado}

M4-1 As funções do software foram apresentadas no treinamento (palavra chave: completitude)

$\square$ Todas $\square$ Quase todas $\quad \square$ Poucas $\square$ Muito poucas $\quad \square$ Não

M4-2 As informaçōes apresentadas no treinamento foram verificadas e estão de acordo com o software (palavra chave: consistência)
$\square$ Todas
Quase todas
Poucas $\square$ Muito poucas
Não

M4-3 O tempo de treinamento para o conteúdo dado foi (palavra chave: cronograma)
$\square$ Muito
$\square$ Suficiente
$\square$ Insuficiente

M4-4 Você ficou satisfeito com o treinamento, parte prática e conceitual (palavra chave: satisfação com o treinamento)
$\square$ Muito
Suficiente
$\square$ Pouco
Muito pouco
$\square$ Não

M4-5 As informaçōes apresentadas (através de: retroprojetor, oral, documentação específica de treinamento, flip chart, vídeo ou qualquer outra para transmissão de conhecimento) no treinamento foram corretas (palavra chave: exatidão das informaçōes)
$\square$ Todas
Quase todas
$\square$ Poucas $\square$ Muito poucas
Não

M4-6 O treinamento ocorreu de forma organizada (palavra chave: organização da apresentação)
Todo
$\square$ Quase todo
$\square$ Pouco $\square$ Muito pouco
$\square$ Não

M4-7 A apresentação visual utilizada no treinamento foi agradável. Exemplo: retroprojetor, datashow (palavra chave: apresentação visual)

$\square$ Sim $\square$ Não

M4-8 O treinamento ocorreu com clareza e não possuiu ambiguidade possibilitando o esclarecimento das funções (palavra chave: clareza, oratória)
Todo
$\square$ Quase todo
$\square$ Pouco $\square$ Muito pouco
บ Não

M4-9 Os exemplos utilizados no treinamento foram suficientes ao entendimento e adequados ao contexto da empresa (palavra chave: exemplos)
$\square$ Todos
Quase todos
$\square$ Poucos
$\square$ Muito poucos
Não 
M4-10 As ilustrações (gráficos, desenhos, figuras) utilizadas no treinamento foram suficientes e esclareceu as suas dúvidas (palavra chave: ilustrações)

$\square$ Todas $\square$ Quase todas $\square$ Poucas $\square$ Muito poucas $\square$ Não

M4-11 As funçōes do software apresentadas no treinamento foram aprendidas e exercitadas (palavra chave: conceitual e prática)
$\square$ Todas
$\square$ Quase todas
$\square$ Poucas $\square$ Muito poucas
$\square$ Não

M4-12 O treinamento apresentou indicações para consultas adicionais disponíveis para você buscar mais informações sobre as suas dúvidas (palavra chave: consultas adicionais bibliográficas)
$\square \operatorname{Sim}$
$\square$ Não
Não sei

M4-13 Ocorreu falha do software no período de treinamento (palavra chave: freqüência de falhas)
$\square$ Bastante
$\square$ Suficiente
$\square$ Pouca
$\square$ Muito pouca $\square$ Não

M4-14 A falha ocorrida afetou o treinamento (palavra chave: gravidade da falha ocorrida)

口 Sim 믐o 


\section{MÓDULO 5 - Documentação de Treinamento}

M5-1 O material de treinamento possui índices gerais e remissivos completos e bem organizados que permite a facilidade para encontrar informaçōes (palavra chave: índices)
$\square \operatorname{Sim}$
$\square$ Não
$\square$ Não sei

M5-2 O material de treinamento possui glossário dos termos utilizados para o seu esclarecimento (palavra chave: glossário)
$\square \operatorname{Sim}$
$\square$ Não
$\square$ Não sei

M5-3 Possui referências cruzadas possibilitando encontrar a informação desejada (palavra chave: referências cruzadas)
$\square \operatorname{Sim}$
$\square$ Não
$\square$ Não sei

M5-4 O material de treinamento apresentou indicaçōes para consultas adicionais disponíveis para buscar mais informações sobre suas dúvidas (palavra chave: consultas adicionais bibliográficas)
$\square \operatorname{Sim}$
$\square$ Não
$\square$ Não sei

M5-5 A forma de apresentação do (material de treinamento) manual garante facilidade de manuseio (palavra chave: manuseio)
$\square$ Bastante
Suficiente
$\square$ Pouco
$\square$ Muito pouco
口 Não 


\section{MÓDULO 6 - Serviços Técnicos Prestados}

M6-1 Você está satisfeito com o suporte da empresa fornecedora do software (palavra chave: atendimento pelo fornecedor)

$\square$ Excelente $\square$ Ótimo $\quad \square$ Bom $\square$ Regular $\square$ Péssimo

M6-2 O contato com o suporte telefônico foi: (palavra chave: contato telefônico)
$\square$ Excelente
ㅁótimo
$\square$ Bom $\square$ Regular
$\square$ Péssimo

M6-3 A sua dúvida ou problema (necessidade) foi sanado em tempo hábil para você executar suas tarefas (palavra chave: tempo hábil para solução do problema)

$\square$ Muito antes $\square$ Antes do prazo $\square$ No prazo $\square$ Fora do prazo $\square$ Não 


\section{MÓDULO 7 - Atualização de Versão do Pacote de Software}

M7-1 O momento é adequado para a atualização do software (palavra chave: implantação da nova versão)

$\square \operatorname{Sim} \quad \square$ Não

M7.2 A demanda pelas novas funçōes requisitadas por você e por outras pessoas é grande (palavra chave: necessidade de novas funções)
Bastante
$\square$ Suficiente
$\square$ Pouca $\square$ Muito Pouca
$\square$ Não

M7-3 A atualização do software vai acrescentar melhoria no software (palavra chave: melhoria nas funções existentes)
Bastante
Suficiente
$\square$ Pouca $\square$ Muito pouca
$\square$ Não

M7-4 A atualização do software substitui alguma função existente ou deixa de aparecer alguma função (palavra chave: substituição de funções)

$\square \operatorname{Sim} \quad \square$ Não $\quad \square$ Não sei

M7-5 Ocorreram mudanças nos processos e fluxos de informações do setor que o software não conseguirá atender (palavra chave: mudanças de processos)
Bastante
$\square$ Suficiente
$\square$ Pouca $\square$ Muito Pouca
口 Não

M7-6 Os processos existentes na empresa estão automatizados (palavra chave: automatização de processos)
$\square$ Todos
Quase todos
Poucos
$\square$ Muito poucos
प Não

M7-7 A nova versão já está implantada em outra empresa (palavra chave: teste da nova versão)

$\square \operatorname{Sim} \quad \square$ Não $\quad \square$ Não sei 